
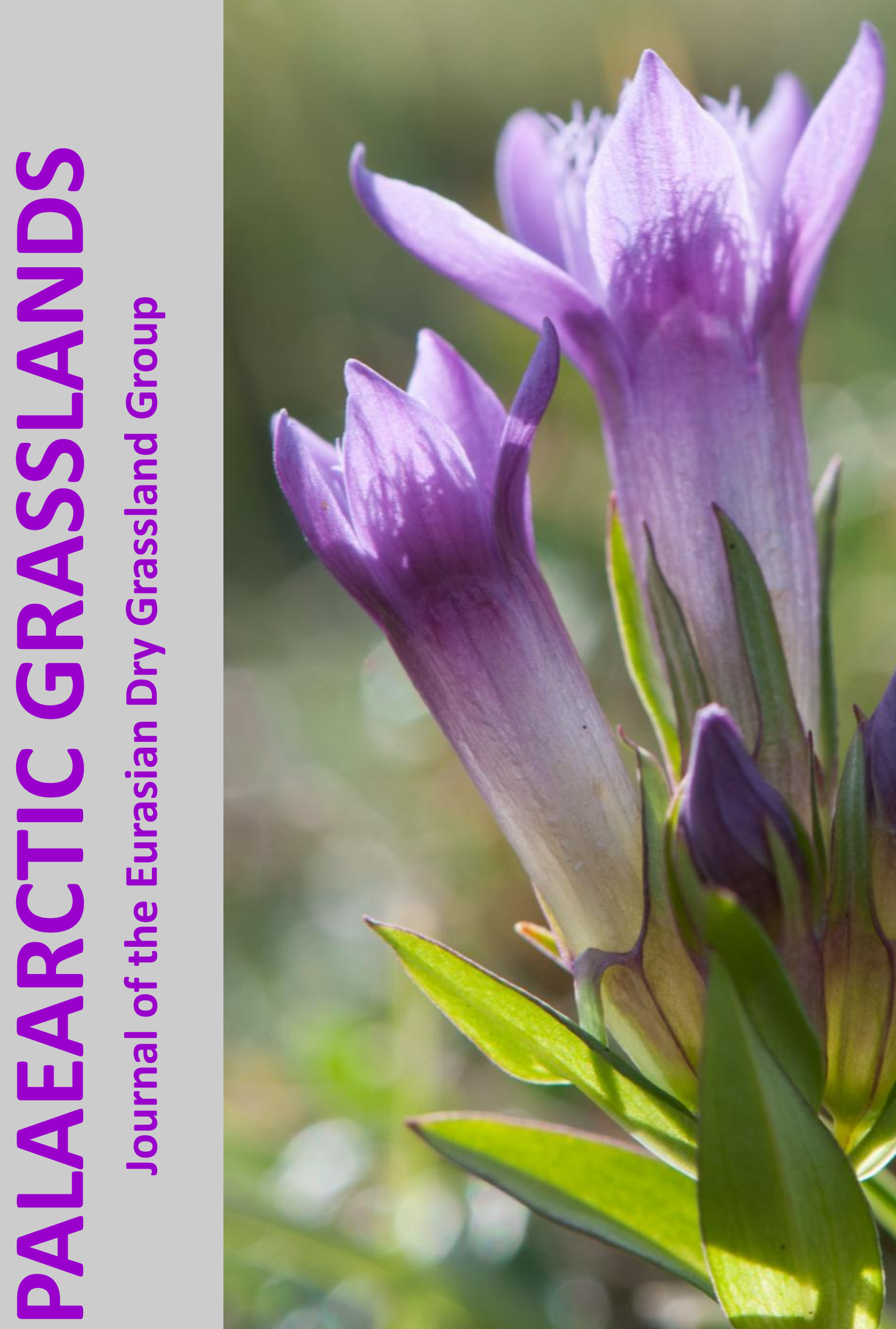


\section{Table of Contents}

Editorial

News

Photo Story and Photo Competition

$14^{\text {th }}$ EDGG Field Workshop in South Ukraine: Ukrainian steppes along climatic gradients. First call

$17^{\text {th }}$ Eurasian Grassland Conference: Grassland dynamics and conservation in a changing world. Spain, Tolosa, $7-13^{\text {th }}$ September 2020. First call

Report on the International Symposium on Grassland Ecology and Conservation in Hohhot, Inner Mongolia, China

EDGG Publications

Pachlatko, J. et al. Alpine grassland vegetation at Gornergrat (Canton of Valais, Switzerland): Vegetation mapping for environmental planning

Photo Story

Short Contribution

Recent Publications of our

Members

Forthcoming Events

About EDGG

\section{Palaearctic Grasslands}

ISSN 2627-9827

DOI 10.21570/EDGG.PG43

Palaearctic Grasslands, formerly published under the names Bulletin of the European Dry Grassland Group (Issues 1-26) and Bulletin of the Eurasian Dry Grassland Group (Issues 27-36) is the journal of the Eurasian Dry Grassland Group (EDGG). It usually appears in four issues per year. Palaearctic Grasslands publishes news and announcements of EDGG, its projects, related organisations and its members. At the same time it serves as outlet for scientific articles and photo contributions.

Palaearctic Grasslands is sent to all EDGG members and, together with all previous issues, it is also freely available at http://www.edgg.org/publications.htm.

The copyright of the included texts, photographs, and other figures remains with their authors. If you wish to re-use them or parts of them, please, obtain the written consent of the authors first.

Scientific articles (Research Articles, Reviews, Forum Articles, Scientific Reports) should be submitted to Jürgen Dengler (juergen.dengler@uni-bayreuth.de), following the Author Guidelines published in Palaearctic Grasslands 37, 6-8. They are subject to editorial review, with one member of the Editorial Board serving as Scientific Editor and deciding about acceptance, necessary revisions or rejection.

All other text contributions (News, Announcements, Short Contributions, Book Reviews,...) should be submitted to Anna Kuzemko (anyameadow.ak@gmail.com) AND Idoia Biurrun (idoia.biurrun@ehu.es). Please check a current issue of Palaearctic Grasslands for the format and style. Deadline for submission to the next issue is 15 November 2019

Photo and art contributions (for general illustrative purposes with captions; proposals for Photo Stories; contributions to Photo and Art Competition) should be submitted to both Photo Editors, Rocco Labadessa (rocco.labadessa@gmail.com) AND Jalil Noroozi (noroozi.jalil@gmail.com). Deadline for submissions to the next Photo Competition on "Grassland plant communities" and Art Competition is 15 November 2019.

Contributions to the sections "Recent Publications of our Members" and "Forthcoming Events" should be sent to Iwona Dembicz (i.dembicz@gmail.com).

Photos included in submissions have always to be delivered in two forms, embedded in the document and as separate jpg (or tiff) files with sufficient resolution for printing (i.e. not less than $1 \mathrm{MB}$ ).

Palaearctic Grasslands is published by EDGG c/o Prof. Dr. Jürgen Dengler, Plant Ecology, BayCEER, University of Bayreuth, Universitätsstr. 30, 85447 Bayreuth, Germany.

\section{Editorial Board}

CHIEF EDITOR:

Anna Kuzemko, Ukraine

DEPUTY CHIEF EDITORS:

Idoia Biurrun, Spain

Jürgen Dengler, Switzerland

EDITORAL BOARD:

Alla Aleksanyan, Armenia

Didem Ambarlı, Turkey

Dolores Byrne, Ireland

Iwona Dembicz, Poland

Edy Fantinato, Italy

Magdalena Firganek-Fulcher, UK

Paul Goriup, UK

Riccardo Guarino, Italy

Richard Jefferson, UK

Gwyn Jones, UK
Rocco Labadessa, Italy

Frank Yonghong Li, China

Ashley Lyons, UK

Lorna Marcham, UK

Jim Martin, Ireland

James Moran, Ireland

Jalil Noroozi, Austria

Arkadiusz Nowak, Poland

Salza Palpurina, Bulgaria

Nina Polchaninova, Ukraine

Solvita Rūsina, Latvia

Stuart Smith, UK

Laura Sutcliffe, Germany

Péter Török, Hungary

Atushi Ushimaru, Japan

Orsolya Valkó, Hungary

Stephen Venn, Finland

On front cover page: Gentianella germanica, a typical late-flowering species of semi-dry basiphilous grasslands of the alliance Bromion erecti (class: Festuco-Brometea), here in the Franconian Switzerland, Bavaria, Germany. Photo: J. Dengler. 


\section{Editorial}

\section{Dear readers,}

The summer 2019 was full of activities for grassland ecologists, such us two successful Field Workshops in Switzerland and Armenia, and several conferences, namely our EGC in Graz, with a wonderful 3-day post-symposium excursion to Slovenia. And of course, lots of sampling that has kept the PG editors busy, like most of you, we guess. This full agenda has even prevented the PG Editors from publishing issue 43 until now, four months after our previous issue.

This new issue contains the first calls for the two main activities of the EDGG in 2020: the Field Workshop, which will take place in Southern Ukraine from 25th May to 3rd June 2020, and the Eurasian Grassland Conference, to be held in the Basque Country (Spain) from 7-13th September 2020, in the small town of Tolosa. Please note the dates, and start planning the coming year!!!

Attending the Field Workshops and Conferences is a big economic challenge for many EDGG members, especially the youngest ones, and those coming from economically poorer countries. Every year the EDGG Executive Committee tries to help some of you, using the financial support provided by our mother organization, the IAVS. However, we feel that if we had a better financial situation, that help could be made even more effective. That's why this year we have initiated two activities that can help us to improve our finances. The first was an auction during the EGC in Graz, the results of which will be reported in issue 44. The second is announced in this issue: the production of EDGG T-shirts. We are currently looking for graphical proposals for these T-shirts, as you can read in our News section. We are also hoping for your participation for the Photo Competition dedicated to "Grassland plant communities. As announced in this issue, the deadline for sending your graphical proposals and entries for the Photo Competition and Photo Story is 15th November 2019.

EDGG editorial activities continue, of course, and in this issue we announce the publication of the 5th EDGGedited Special Feature (SF) in Hacquetia, as well as the call for contributions for the 6th SF in Hacquetia, as well as the 15th EDGG-edited Special Feature in Tuexenia. We also include a call for a potential SF on the topic "The sustainable management of grasslands for the conservation of biodiversity". If you are interested please submit your abstract until 20th October 2019.

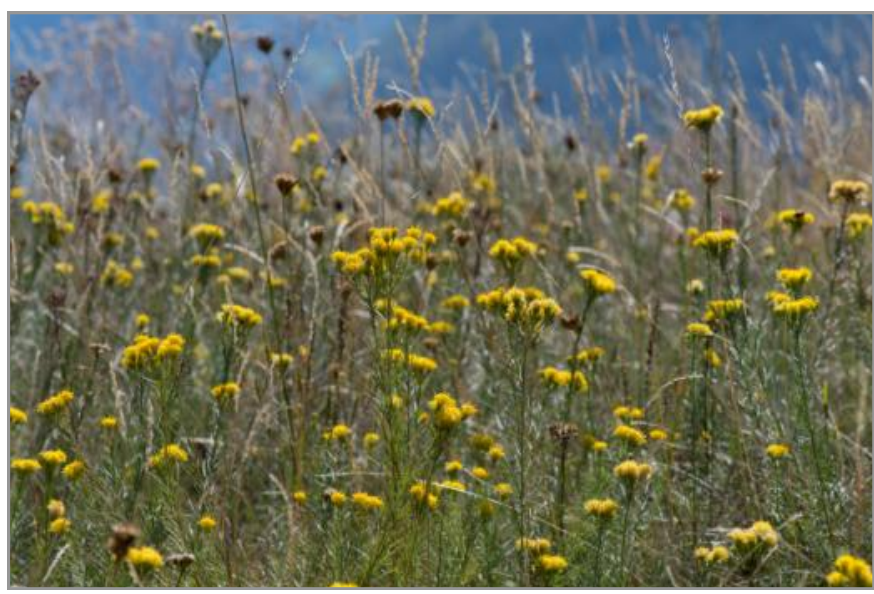

Late-summer aspect of steppic grasslands in the Canton of Valais, Switzerland, with flowering Aster linosyris. Photo: J. Dengler.

We are very happy that PG is receiving increasing attention since its relaunch last year. We are receiving more submissions of research papers than in the past, and we hope that we will be able to publish one good-quality research paper in each issue such as, for example, the one on fine-scale vegetation mapping of alpine grasslands in the Swiss Alps, published in this issue.

Last but not least, I would like to highlight the contribution of Riccardo Guarino, who attended the International Symposium on Grassland Ecology and Conservation at the Inner Mongolia University in China as representative of the EDGG. There he introduced our activities and visited the Grassland Ecosystem Research Station of Inner Mongolia University, as well as several nature reserves in the region. He also demonstrated the EDGG multi-scale sampling methodology of plant diversity. We hope that this experience will be the starting point of further collaboration with colleagues from China and neighbouring countries, which has been a goal of the EDGG Executive Committee for a long time.

Now that the days are getting shorter and shorter, we hope to brighten your evenings with the reading of this new PG issue,

Idoia Biurrun, Deputy Chief Editor idoia.biurrun@ehu.es 


\section{News}

\section{Dear EDGG Members,}

We came up with an idea of producing special EDGG Tshirts. We know that many of you have artistic talent and enjoy creative activities. That is why, we would like to invite you to the process of the T-shirt creation! Until 15 November 2019 we are waiting for your graphical proposals of what can be printed on the T-shirts. Jury A jury consisting of the EDGG Executive Committee will vote on the motives and select the three best proposals. They will be used to produce EDGG T-shirts, which we will sell during Eurasian Grasslands Conferences and online. Having no membership fee, EDGG will use the surplus gained from selling the Tshirts to support its activities, e.g. for travel grants to attend EDGG events.

Please, prepare your motives according to the following rules:

- The topic of the graphic must be related with Palaearctic dry grasslands
- Single graphics or plates with graphics are welcome

- Preferentially vector graphics (bitmap possible, but only in high resolution and when it is possible to convert it to a vector)

- Do not use too many colours and too large areas covered with a colour (use rather contours)

- Gradients of colours are not allowed (i.e. for each element of the graphic use one colour, not a gradient from one colour to another)

The colour of the T-shirt will be selected later to fit the winner motives.

One person can send up to three proposals. Please send them to Iwona Dembicz (i.dembicz@gmail.com) with “EDGG T-shirt motive" in the title of the e-mail. The jury reserves the right to reject motives that do not meet the abovementioned criteria and printing standards.

Iwona Dembicz, Warsaw, Poland i.dembicz@gmail.com

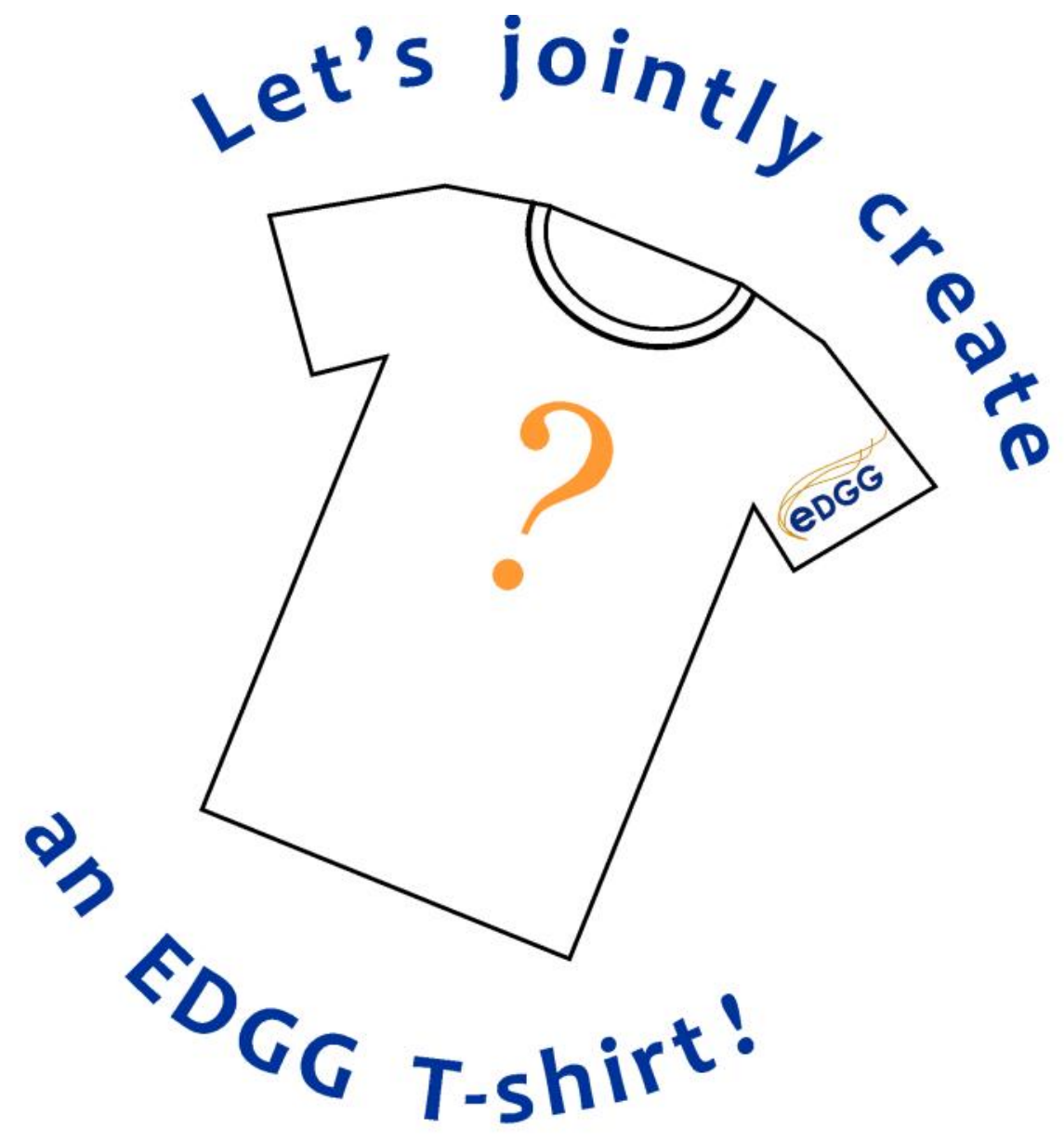




\section{Photo Story and Photo Competition}

The call for the current Photo Competition is dedicated to the theme "Grassland plant communities", looking for shots that best highlight the peculiar structure and composition of grassland vegetation types.

You are invited to send up to three high-quality photographs within the competition theme (full size JPEG or TIFF images, at least $300 \mathrm{dpi}$ ) together with captions giving information on the subject (species name, date, place name) and, possibly, technical details (camera, lens, aperture and exposure time).

The selection will be made by a jury of at least five members from the Editorial Board of the journal. The three best shots will be awarded with full space in the next issue, but we reserve the right to use further submitted materials for illustrative purposes in other parts of the issue.

If you feel you can contribute with your shots, don't be shy! Everyone can join the competition!

Contributions for the Photo Story section are always welcome. Photo Story is an open space where members can submit their own photo collection on a certain grassland- related topic of their choice. High-quality photos should be provided together with their captions (at least species names or landscape description), a brief text and possibly other graphical elements (like a map or a drawing). The selection of photos should fit for 1-4 pages and the proponents should already propose a preliminary layout (in PDF or MS Word format), which will be finally typeset by Editors. As an example, you may take a look at the Photo Stories published in previous PG issues.

If you want to contribute to these sections, or if you simply want to help us enriching the aspect of the journal, please submit your photos or artwork together with required information to Rocco (rocco.labadessa@gmail.com) and Jalil (noroozi.jalil@gmail.com).

Deadline for photo submissions is 15 November 2019!

Rocco Labadessa, Bari, Italy

rocco.labadessa@gmail.com

Jalil Noroozi, Vienna, Austria noroozi.jalil@gmail.com

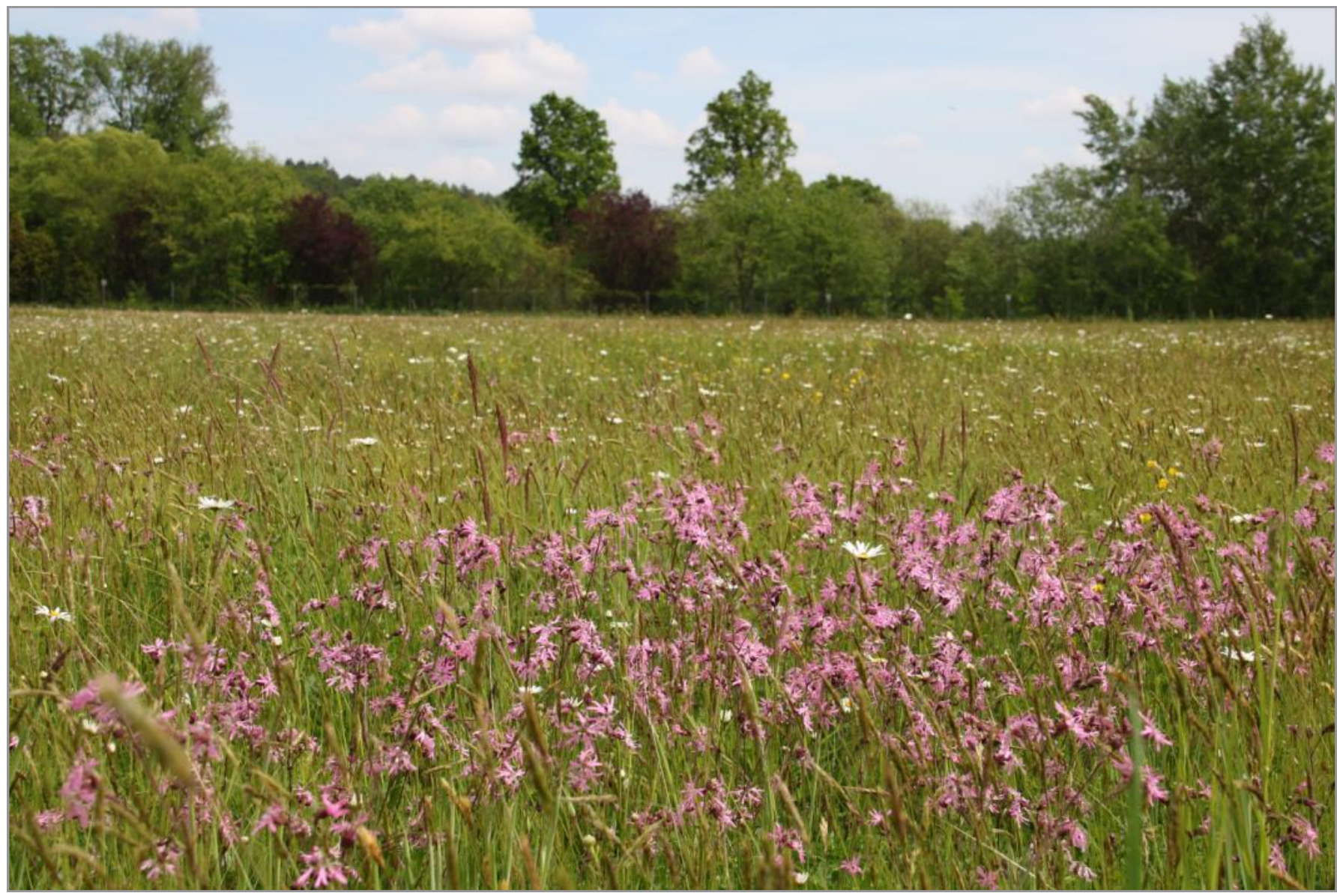

Restored lowland hay-meadow with Lychnis flos-cuculi and Leucanthemum vulgare, Fürstenfeld, East-Styria, Austria. Photo: P. Sengl. 


\title{
EDGG Event
}

\section{$14^{\text {th }}$ EDGG Field Workshop: \\ Ukrainian steppes along climatic gradients}

\author{
Ukraine, 25 May - 3rd June 2020
}

\section{First call}

The $14^{\text {th }}$ EDGG Field Workshop will take place in Ukraine from $25^{\text {th }}$ May to $3^{\text {rd }}$ June 2020 . The aim of the workshop is to sample steppe grasslands along climatic gradients (precipitation and temperature) using a standardized sampling approach (Dengler et al. 2016).

We will start in Kherson city in Southern Ukraine, moving northward to Poltava region, and ending the workshop in Kyiv (Fig. 1). We will sample five different climatic types of steppes: desert steppes, grass steppes, herb-grass steppes, herb-rich grass steppes and meadow steppes. During the first day we will focus on the desert steppes of the Syvash Lake (Churiuk Island or Kuyuk-Tuk Island, Syvashyk Liman). This type of steppe is classified as Artemisio tauricaeFestucion valesiacae (Kolomiychuk \& Vynokurov 2016). Annual precipitation of this locality is $350 \mathrm{~mm}$ and the mean annual temperature is $10.5^{\circ} \mathrm{C}$. In the following two days we will continue sampling in grass steppes (Troitska gulley, Molochna River Valley, Zaporizhzhia region). Thereafter, we will

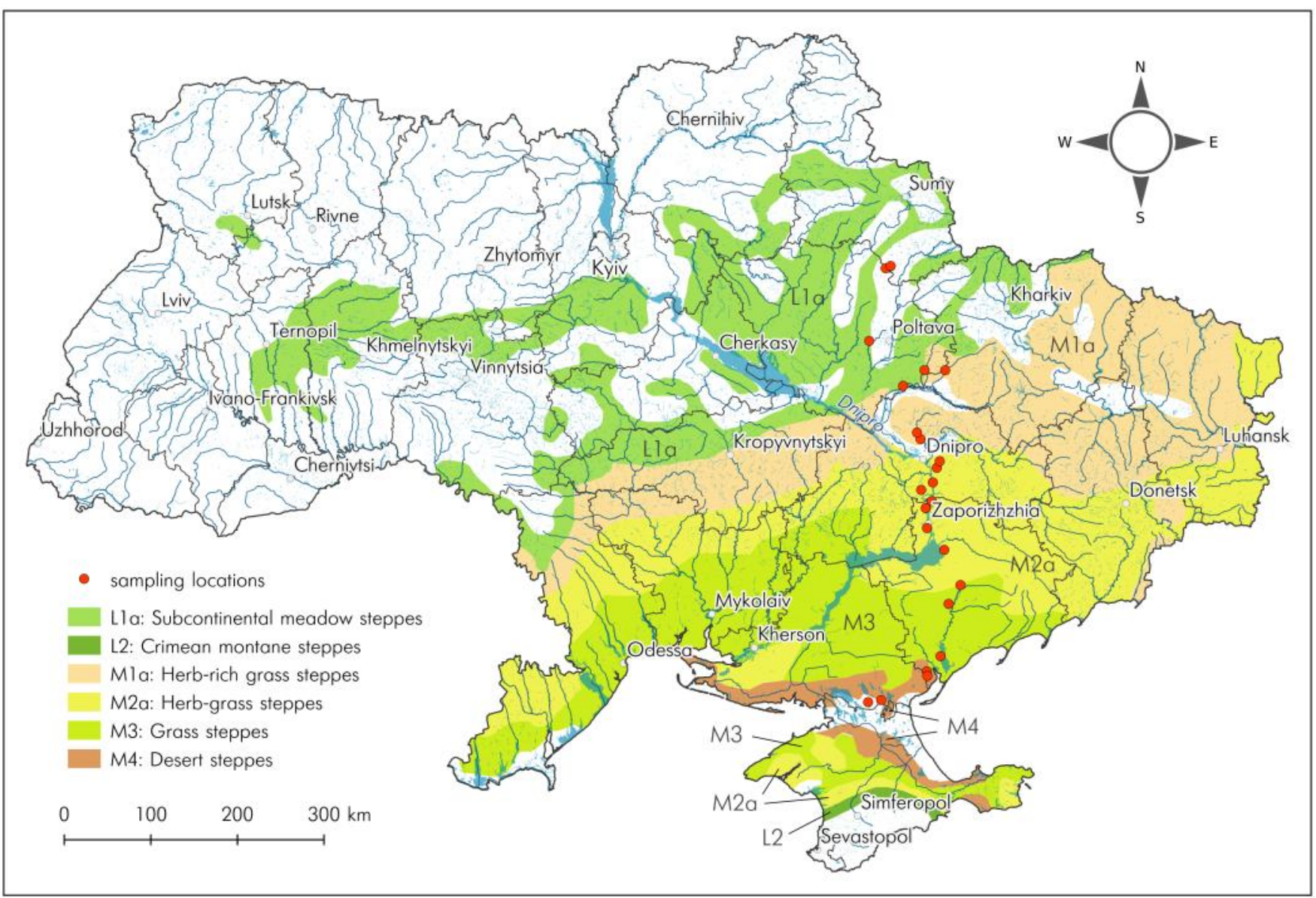

Fig. 1. Map of Ukraine with approximate sampling locations. Vegetation types based on the potential natural vegetation map of Europe (Bohn et al. 2000). 
move northward, sampling herb-bunchgrass and herb-rich grass steppes in Zaporizhzhia, Dnipro, Poltava and Kharkiv regions. The possible preliminary localities are: Khortytsia Island, Dnipro River Valley, Dniprovi Porohy Regional Landscape Park (Fig. 2) and the Oril River Valley. The last type we will sample is the meadow steppes of the Forest-Steppe zone in Poltava region, with annual precipitation of $600 \mathrm{~mm}$ and mean annual temperature of $7.3^{\circ} \mathrm{C}$.

We expect up to 20 (exceptionally up to 25 ) participants in total, including 3-4 organizers.

Approx. costs: $800 €$ (postdoc/professor, non IAVS member), $700 €$ (postdoc/professor \& IAVS member OR student/ PhD student \& non IAVS member), $600 €$ (student/ PhD student \& IAVS member. IAVS travel grants will be available upon application based on motivation letter and financial need.

A detailed call with information on how to register for the workshop will follow in the next issue of Palaearctic Grasslands. If you have questions before that, please send an email to denys.vynokurov@gmail.com.

\section{References}

Bohn, U., Gollub, G. \& Hettwer, C. 2000. Karte der natürlichen Vegetation Europas / Map of the Natural vegetation of Europe. Bundensamt für Naturschutz, Bonn, DE.
Dengler, J., Boch, S., Filibeck, G., Chiarucci, A., Dembicz, I., Guarino, R., Henneberg, B., Janišová, M., Marcenò, C., (...) \& Biurrun, I. 2016. Assessing plant diversity and composition in grasslands across spatial scales: the standardized EDGG sampling methodology. Bulletin of the Eurasian Grassland Group 32: 13-30.

Kolomiychuk, V. \& Vynokurov, D. 2016. Syntaxonomy of the Festuco-Brometea class vegetation of the Azov sea coastal zone. Hacquetia 15/2: 79-104.

Local organizers:

Denys Vynokurov, Kyiv, Ukraine denys.vynokurov@ukr.net

Ivan Moysiyenko, Kherson, Ukraine ivan.moysiyenko@gmail.com

Dariia Shyriaieva, Kyiv, Ukraine darshyr@gmail.com

EDGG Field Workshop Coordinators:

Iwona Dembicz, Warsaw, Poland i.dembicz@gmail.com

Idoia Biurrun, Bilbao, Spain idoia.biurrun@ehu.es

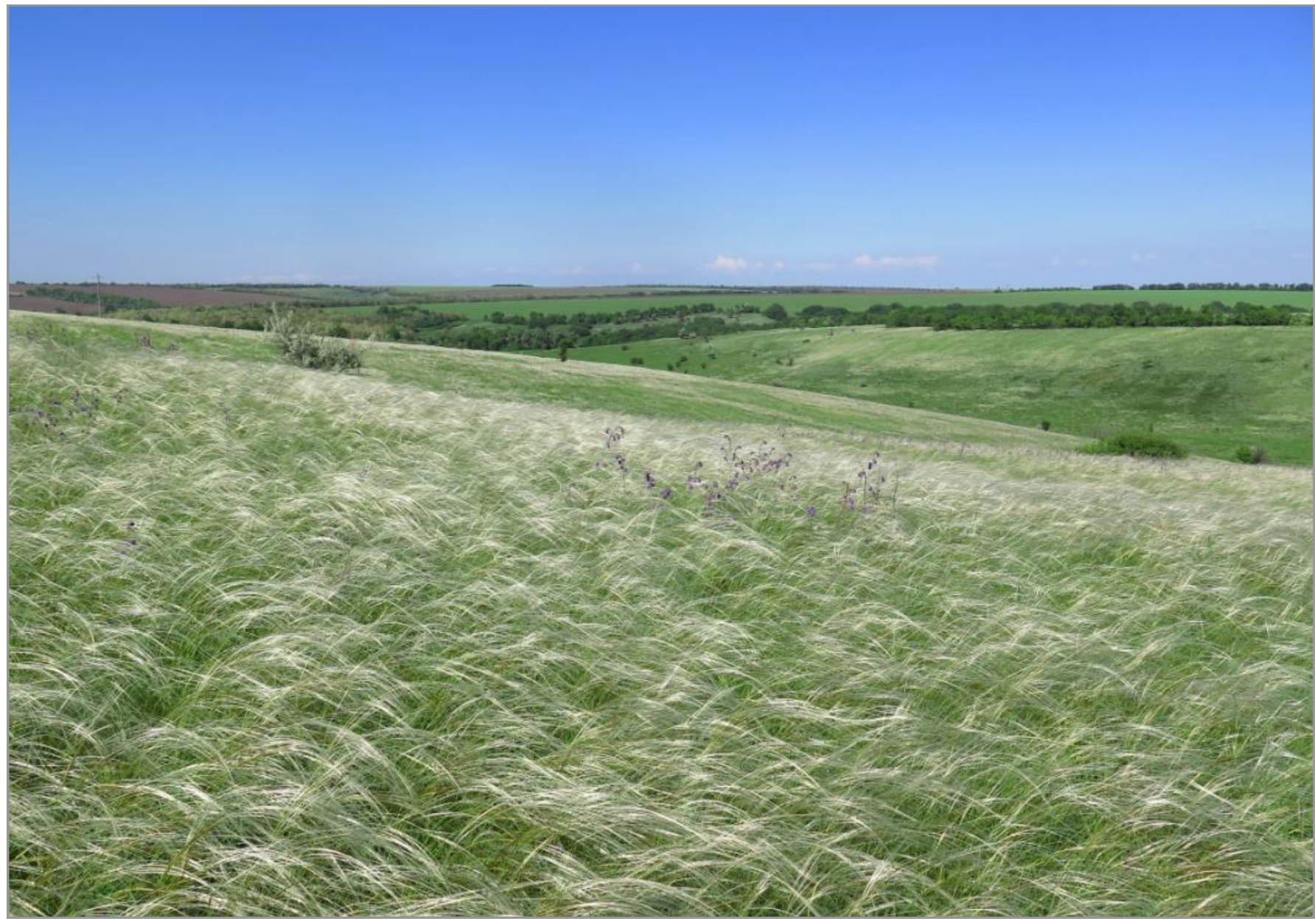

Fig. 2. Forb-bunchgrass steppe in "Dniprovi Porohy" Regional Landscape Park, Ukraine. Photo: V. Maniuk. 


\section{$17^{\text {th }}$ Eurasian Grassland Conference Grassland dynamics and conservation in a changing world}

\section{eDGG}

Grassland research and conservation
Spain, with Tolosa town as the conference venue, $7-13^{\text {th }}$ September 2020

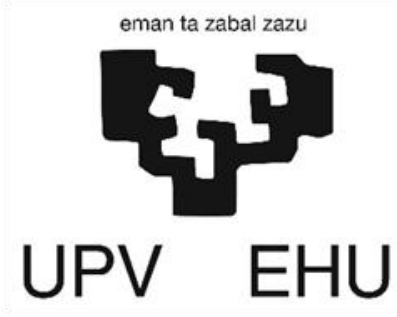

First call

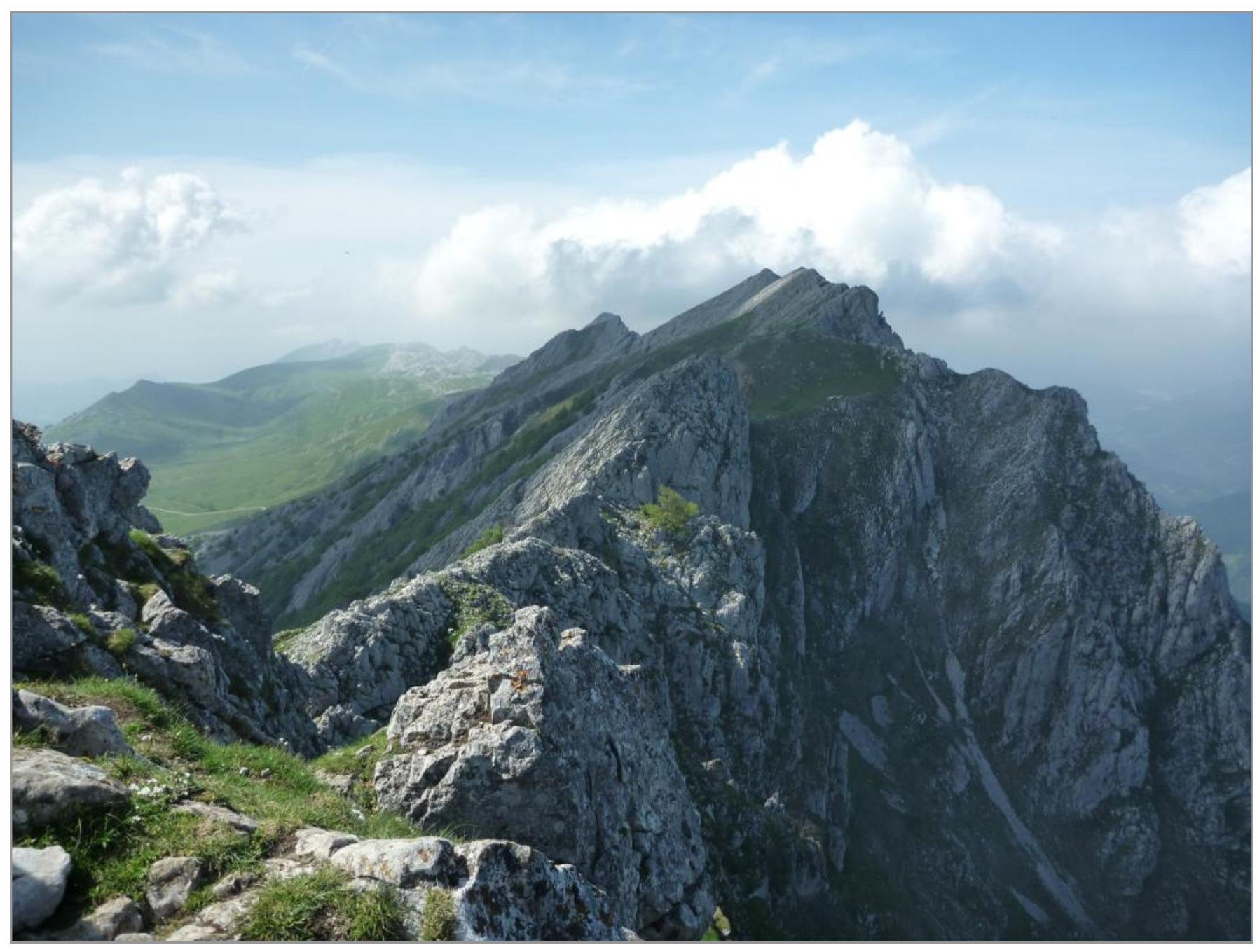


Global change is one of the major threats of natural and semi-natural grasslands, which are facing important challenges for their conservation, caused by land -use and climatic change. We would like to invite you to Tolosa (Basque Country, Spain) to participate in the $17^{\text {th }}$ Eurasian Grassland Conference (EGC), with the theme of Grassland dynamics and conservation in a changing world.

We offer you the opportunity to hear about the latest advances in grassland science and conservation, exchange and improve your knowledge and networking, and have a good time. The conference will be full of events, e.g. talks and poster sessions, workshops, grassland party, and mid- and post-conference excursions.

We hope to meet you in the Basque Country!! The Organizing Committee

\section{Dates and Venue}

The $17^{\text {th }}$ EGC of the Eurasian Dry Grassland Group (IAVS Working Group) will be held in Tolosa (Basque Country, Spain, 20,000 inh., http://bit.ly/Tolosa wiki; https:// tourism.euskadi.eus/en/) from Monday $7^{\text {th }}$ to Sunday $13^{\text {th }}$ September 2020.

This historic town is located in the valley of the Cantabrian River Oria (Fig. 1), and is $25 \mathrm{~km}$ away from San Sebastian (Donostia in Basque), a famous touristic location with three beaches, at 20-30 min train distance (Fig. 2). In medieval times, Tolosa was a very important checking point among the Kingdoms of Navarre and Castile, France and the Can- tabrian harbours. Currently it hosts many important cultural events and a traditional market every Saturday.

The registration and conference sessions will be held in the Antonio Maria Labaien Cultural Centre (Kultur Etxea), in Tolosa city centre: Trianguloa, 1 (Figs. 3 and 4).

\section{Topics}

\section{Grassland dynamics and conservation in a changing world}

Natural and semi-natural grasslands are currently facing several challenges in the context of global change, both regarding land-use and climatic change. Palaearctic grasslands are among the most negatively impacted by humans, characterized by a strongly declining trend in habitat extent and intactness, as well as species diversity and abundance since the second half of the $20^{\text {th }}$ century. Both intensification of management and cessation of extensive traditional land use are affecting the conservation of semi-natural grasslands. In this context, we want to focus on the following topics:

- Succession and species turnover in abandoned grasslands, in the context of cessation of traditional land use.

- Biodiversity of urban grasslands, which may often act as refuges for endangered fauna, flora and habitats.

- Above- and belowground grassland diversity, including plants, animals, mycobiota and bacteria, in the context of grassland management type.

- Grassland conservation and global change: historical changes and future prospects on grassland extent and quality in the context of land-use changes and climate change.

In addition to these, any other contribution relevant to Palaearctic grassland diversity, classification, management and conservation, is welcome.

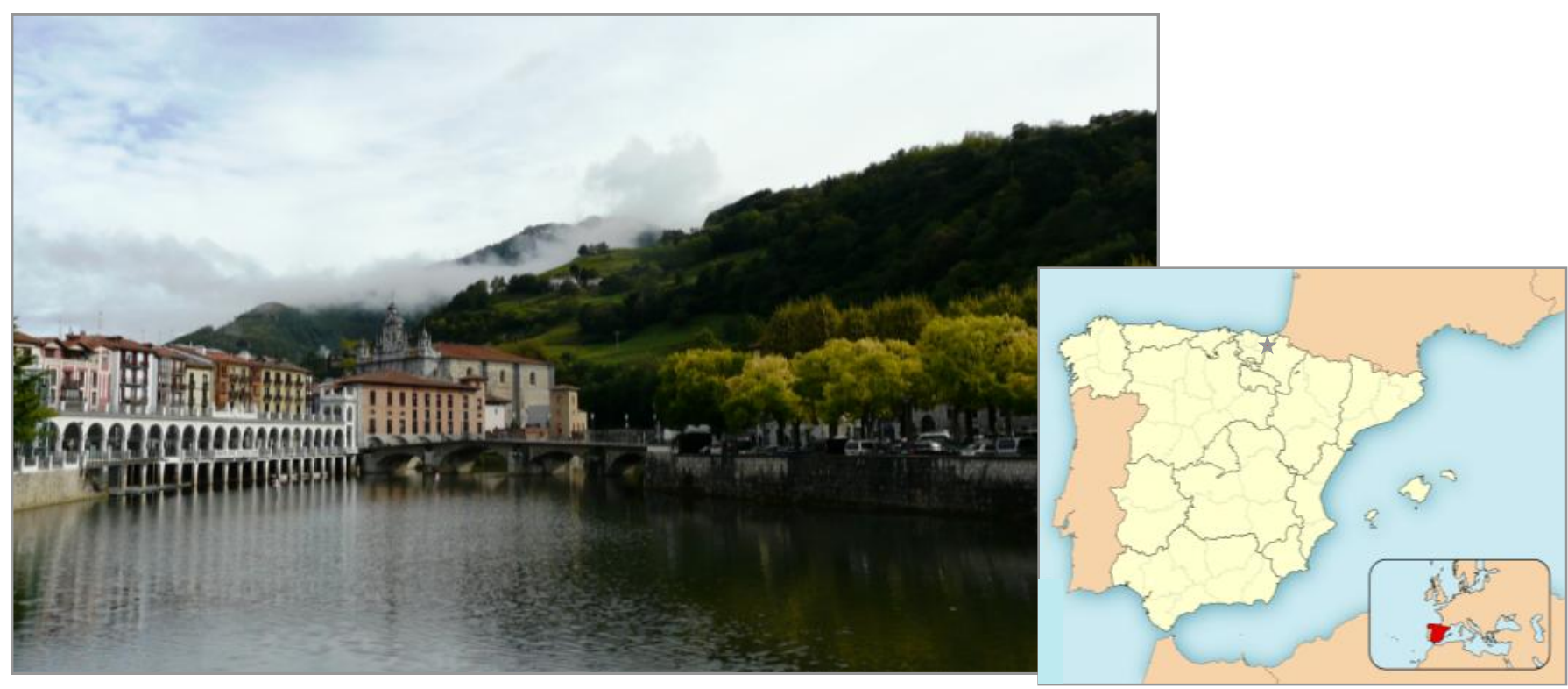

Fig. 1. View of Tolosa and its location on the Iberian Peninsula. Photo: I. Biurrun. 


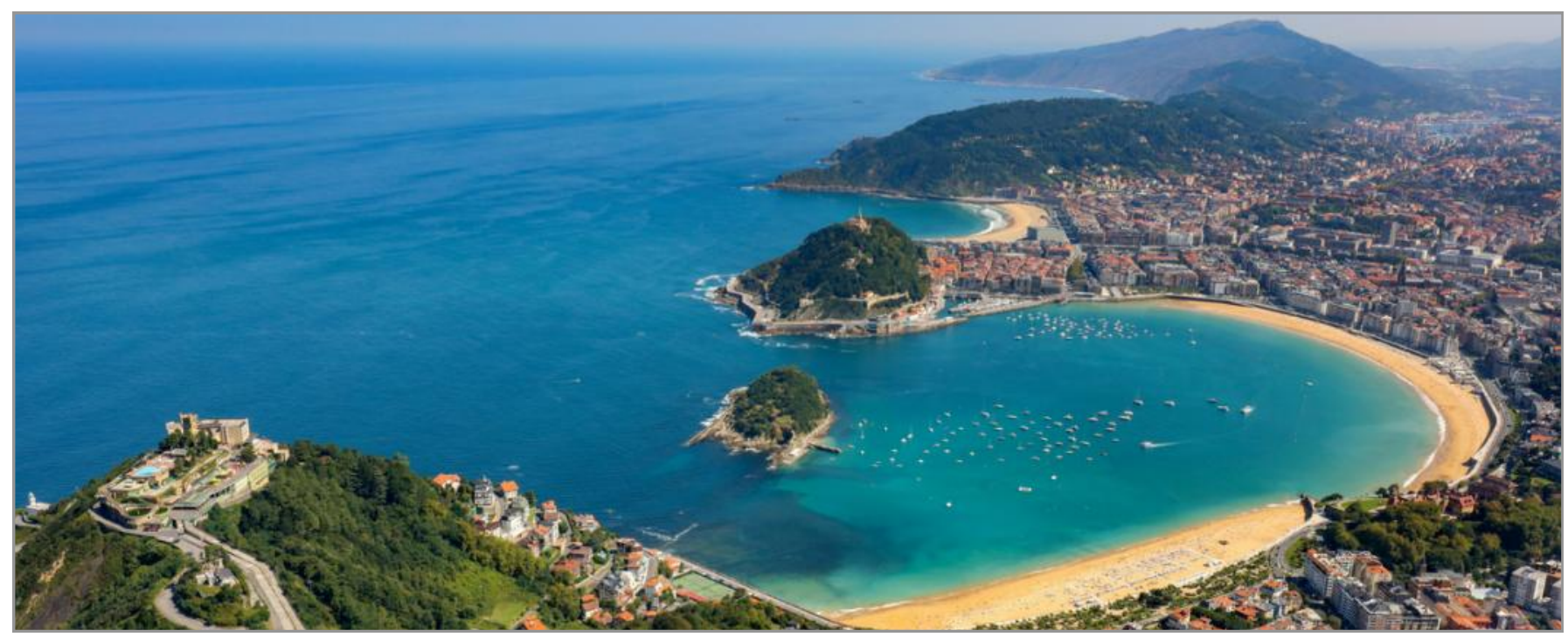

Fig. 2. View of San Sebastian, on the Cantabrian coast. Photo: http://bit.lv/Donostia Concha.

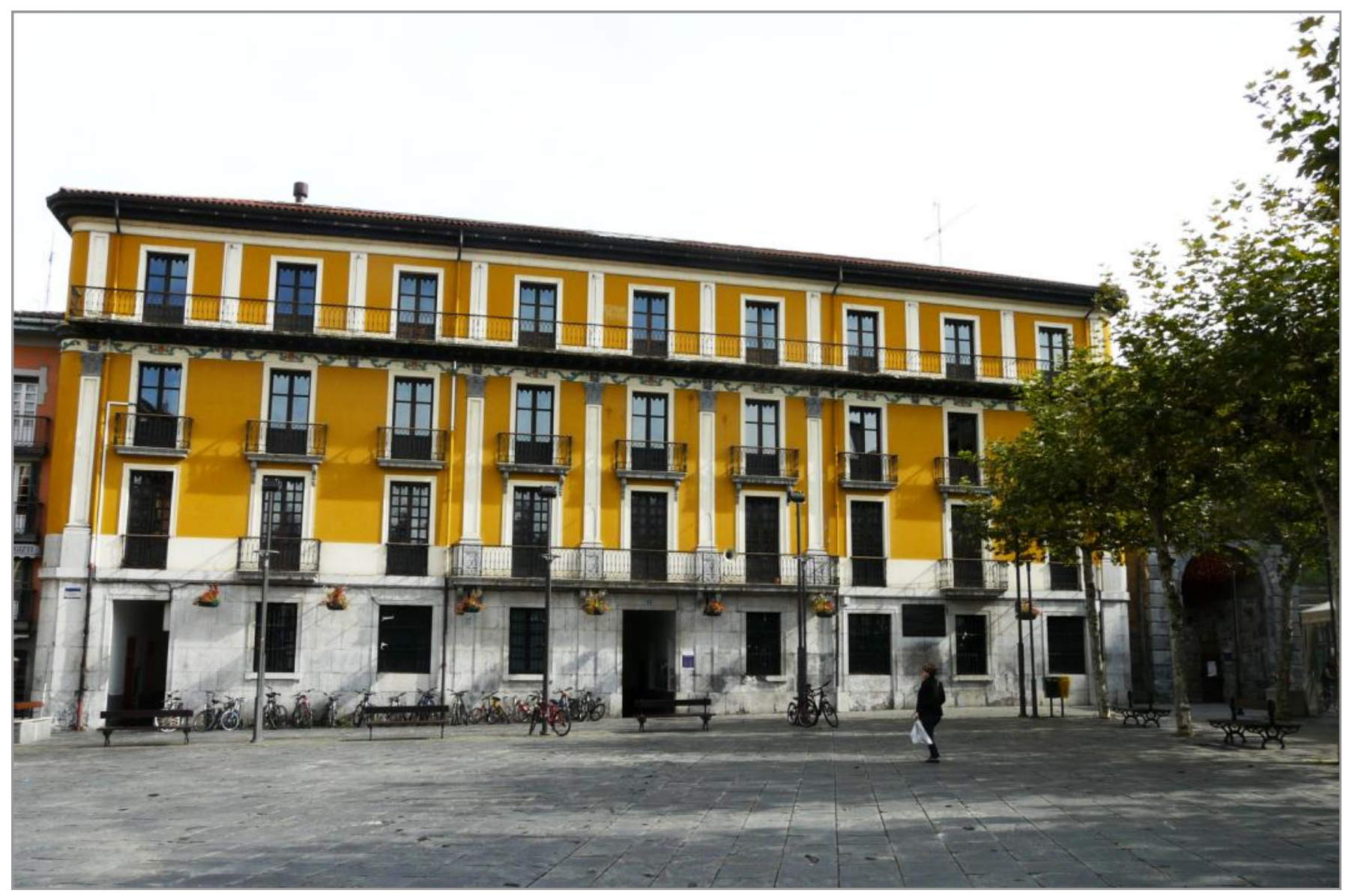

Fig. 3. Venue of the EGC in the Antonio Maria Labaien Cultural Centre (Tolosa city centre). Photo: I. Biurrun. 


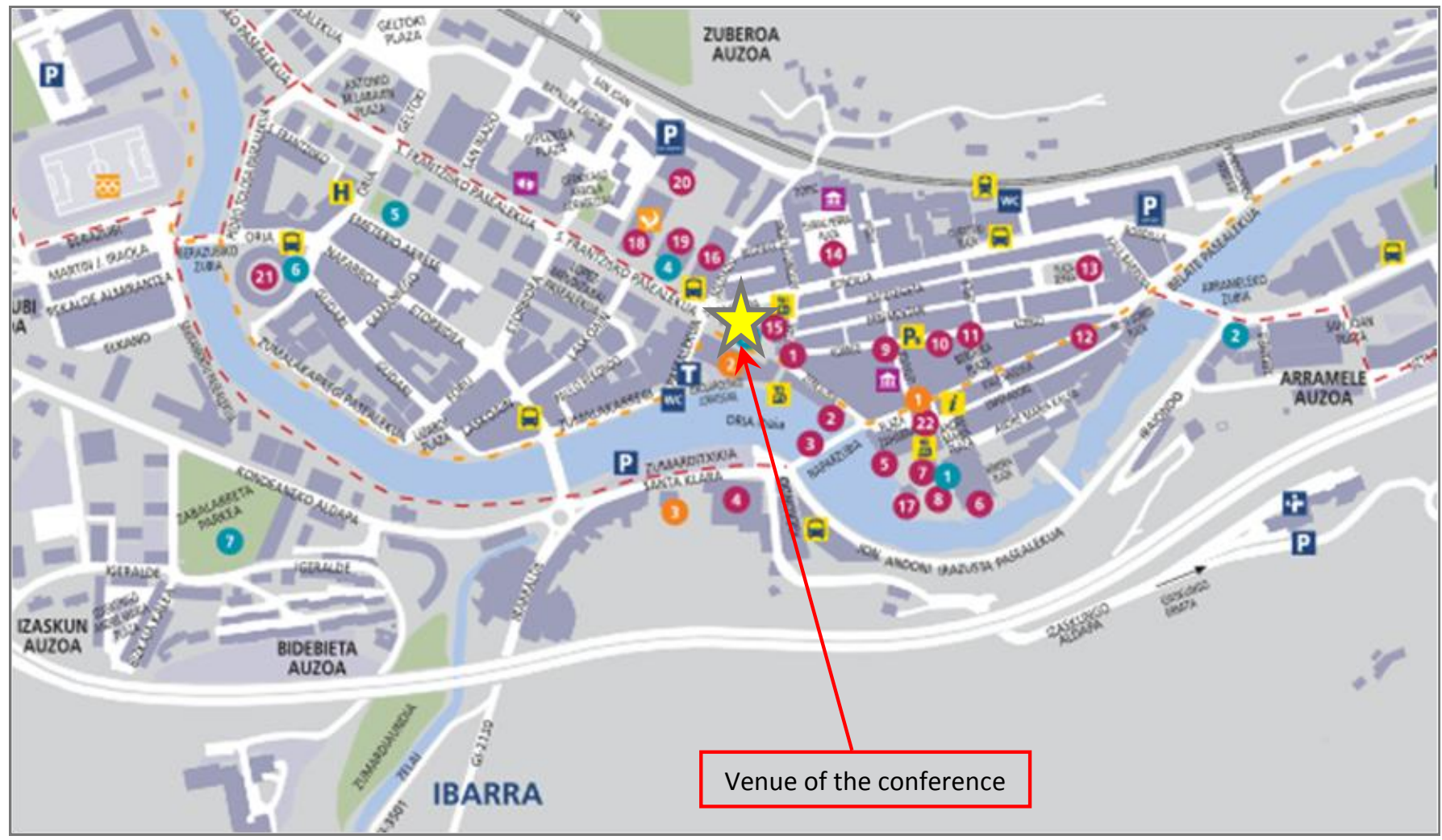

Fig. 4. Location of venue in the map of Tolosa.

\section{Programme outline}

\begin{tabular}{|c|c|c|}
\hline Monday & September $7^{\text {th }}$ & $\begin{array}{l}\text { [Potential technical work- } \\
\text { shops], EGC registration, } \\
\text { Welcome drink }\end{array}$ \\
\hline Tuesday & September $8^{\text {th }}$ & $\begin{array}{l}\text { EGC registration, } 1^{\text {st }} \text { session } \\
\text { day }\end{array}$ \\
\hline Wednesday & September $9^{\text {th }}$ & $\begin{array}{l}\text { Mid-conference excursion, } \\
\text { grassland party }\end{array}$ \\
\hline Thursday & September $10^{\text {th }}$ & $\begin{array}{l}\text { Conference, } 2^{\text {nd }} \text { session day, } \\
\text { EDGG General Assembly }\end{array}$ \\
\hline $\begin{array}{l}\text { Friday to } \\
\text { Sunday }\end{array}$ & $\begin{array}{l}\text { September 11- } \\
13^{\text {th }}\end{array}$ & $\begin{array}{l}\text { Post-conference excursion } \\
\text { (optional) }\end{array}$ \\
\hline
\end{tabular}

\section{Excursions}

\section{Mid-conference excursion to Aizkorri-Aratz Natural Park, 9 September}

The highest peak in the Basque Autonomous region, Aitxuri (1551 $\mathrm{m}$ a.s.l.) is located in this limestone mountain range, which limits the Cantabrian and Mediterranean basins. Basque legends place one of the houses of the goddess Mari, a personification of Mother Earth and all the elements it contains, in these summits. In these mountains, we can find such treasures as the Tunnel of San Adrian, with a chapel inside, crossed by a medieval road, and the Arrikrutz cave, with galleries full of giant stalactites. Near the summit of the Aizkorri peak, there is a chapel and a small refuge (Fig. 5).

In 2006, the Aizkorri mountain range became the AizkorriAratz Natural Park, with 19,400 ha. The main entrance to the park is from the impressive Sanctuary of Arantzazu, over a steep ravine at $750 \mathrm{~m}$ a.s.l., which has great artistic and architectonic value (Fig. 6).

Several forest types are abundant in these mountains, mostly beech forests, but there is also space for seminatural grasslands in many open areas that have been retained for extensive grazing, especially in Urbia and Oltza open fields, at approx. $1000 \mathrm{~m}$ a.s.l. They have been used for the summer grazing of sheep since the Neolithic, as testified by several megalithic monuments (Figs. 7 and 8). Nowadays, also cattle and horses are grazing in these fields, but the indigenous latxa breed has been traditionally bred, mainly for its milk, which is used to make Idiazabal cheese. Shepherds join in small groups of txabolas (small mountain houses) during the summer months. Besides shepherding, charcoal-making has also been a traditional activity in these mountains.

Many species of mammals, birds and amphibians inhabit these forests, pastures and cliffs: alpine newt (Ichthyosaura alpestris), Iberian frog (Rana iberica), Peregrine falcon (Falco peregrinus), Griffon vulture (Gyps fulvus), Egyptian vulture (Neophron percnopterus), Alpine chough (Pyrrhocorax graculus), Red-billed chough (Pyrrhocorax pyrrhocorax), European snow vole (Chionomys nivalis), European pine marten (Martes martes), European polecat 


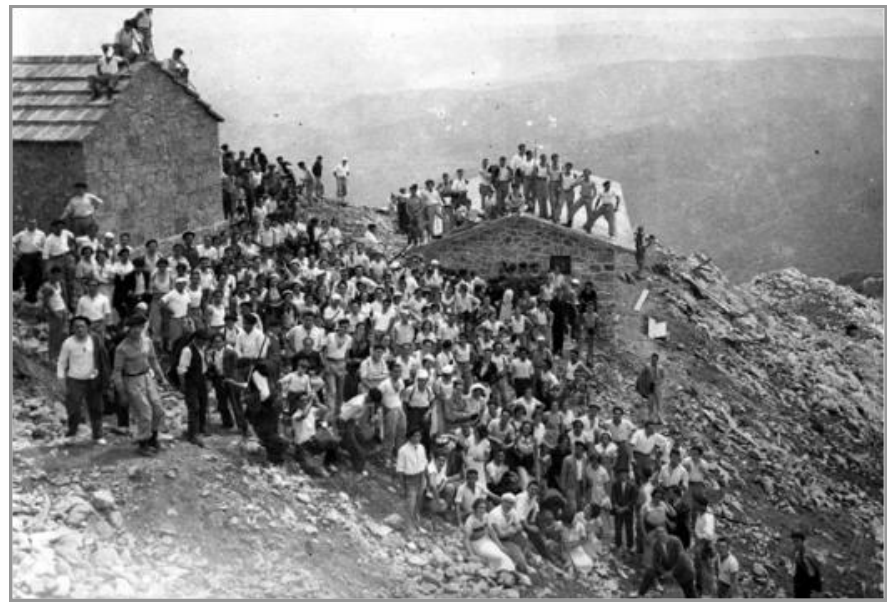

Fig. 5. Inauguration day of the refuge in Aizkorri, $8^{\text {th }}$ July 1934. Photo: I. Ojanguren.

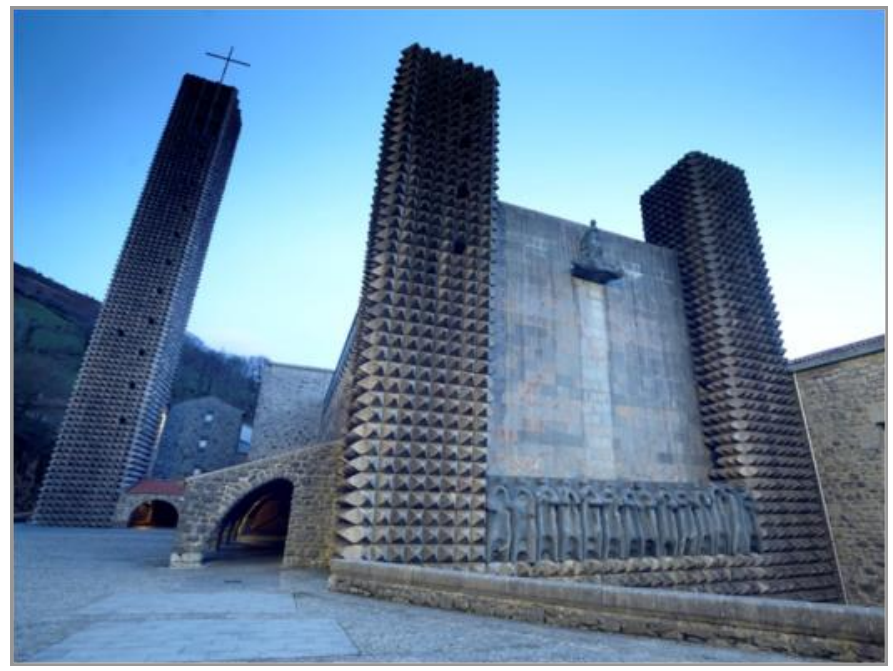

Fig. 6. Front view of the Sanctuary of Arantzazu, with 14 apostles by the Basque sculptor Jorge Oteiza. Photo: http://www.oñatiturismo.eus/en/listings/arantzazukosantutegia/.

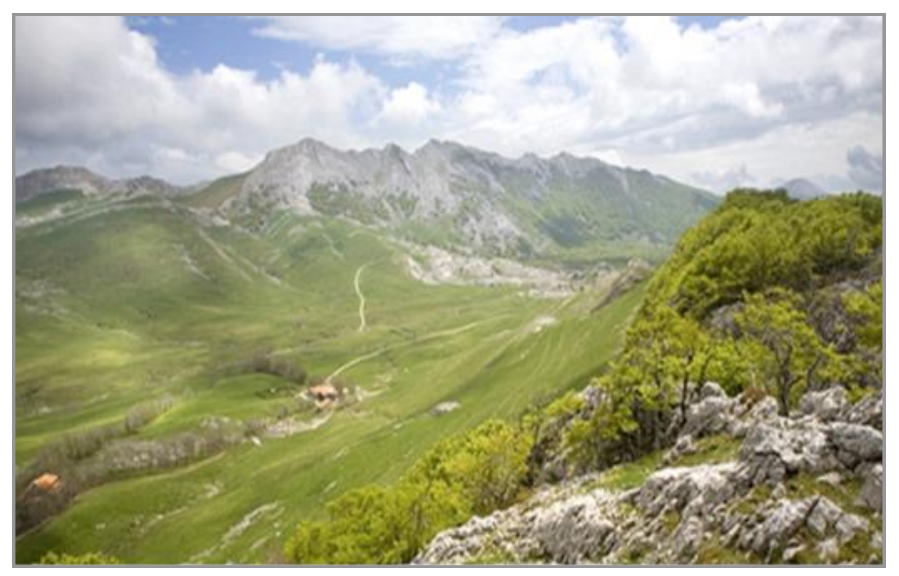

Fig. 7. Urbia and Oltza open fields in Aizkorri-Aratz. Photo: http://bit.ly/Urbia field.
(Mustela putorius), European wildcat (Felis silvestris) and several bat species.

On our way to the mountain summit, we will cross dry grasslands with Helictotrichon cantabricum and Sesleria autumnalis and basophilous thorny-cushion scrub with Genista occidentalis, successional stages of Quercus pubescens forests. We will go up to the Urbia fields, at $1100 \mathrm{~m}$ a.s.l., through beech forests. In Urbia, grasslands of the Violion caninae and heathlands of the Daboecion cantabricae form the traditional pastoral landscape. Back on the limestone steep slopes towards the summit, rocky grasslands of the class Festuco-Ononidetea occur, with Teucrium pyrenaicum, Carex caryophyllea, C. ornithopoda, Festuca rectifolia, Brachypodium rupestre, Acinos alpinus, Thymus praecox, etc. At higher elevations, we will find subalpine dry grasslands with Festuca gautieri subsp. scoparia and Agrostis schleicheri (Festucion scopariae). Near the summit, limestone cliffs harbor rupicolous communities, with Potentilla alchimilloides, Hornungia alpina subsp. auerswaldii, Dethawia splendens and Erinus alpinus (Sedo-Seslerion hispanicae), as well as mesic chionophilous grasslands with Sesleria caerulea (Primulion intricatae).

The grassland party will be held near the Arantzazu Sanctuary, at the Gomiztegi shepherd school.

Post-conference excursion to the Basque Country and $\mathrm{Na}$ varre (optional, restricted to approx. 40 people)

\section{September}

Atlantic valleys and mountains in Gipuzkoa and Northern Navarre: Coastal heathlands in Jaizkibel. Mountain acidic grasslands, heathlands and mires in Belate. Night in Isaba.

\section{September}

Pyrenean mountains: subalpine and alpine grasslands in Belagua and Larra. Night in Beire/Tudela.

\section{September}

Ebro valley (Bardenas Reales): Mediterranean grasslands and scrub. Urbasa mountain range: submediterranean dry grasslands. Night near Bilbao, in hotel with transfer to airport (most flights to European cities start early in the morning).

\section{Accommodation during the conference}

Accommodation should be booked independently by each participant. A list of accommodation options will be provided in the second circular.

\section{Travelling}

Tolosa town may be reached by train or bus from San Sebastian. The best option is to take a direct bus from Bilbao airport to San Sebastian (1 hour and $8 \mathrm{~min}$ ), and, close to the bus station, take a train to Tolosa (20 or $30 \mathrm{~min}$ ). There is also the possibility to fly to Biarritz airport, in France, and travel by bus to San Sebastian (45 min). Details about travelling will be provided in the second circular. Fig- 


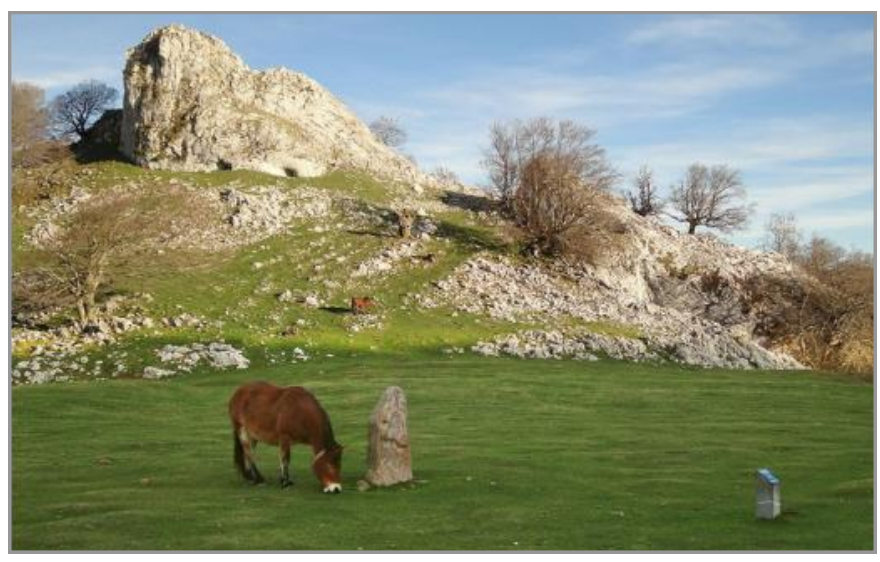

Fig. 8. Menhir of Zorrotzarri. Photo: https:// fr.wikipedia.org/wiki/Menhir de Zorrotzarri.

ure 9 shows the location of Tolosa in relation to Bilbao and Biarritz airports.

\section{Registration}

You can register and submit your abstract at the web page of the conference, which is expected to be launched soon (all EDGG members will be informed when the website is available).

Details of the fees will also be provided in the second circular. The fees will cover: attendance to the scientific sessions, coffee breaks and lunches between the sessions, grassland party, attendance pack, transport during the mid- and postconference excursions.

\section{Visas and deadlines}

If you require an official letter of invitation to attend the conference, please contact the Chair of the Organizing Committee, Idoia Biurrun, after registering (Department of Plant Biology and Ecology, University of the Basque Country (UPV/EHU) P.O. Box 644, 48080 Bilbao, Spain. Email: idoia.biurrun@ehu.eus). This letter does not represent any commitment on the part of the organizers to provide financial support for you; it is only for the purpose of obtaining your visa or other such purposes.

We hope to offer a limited number of travel grants for IAVS members. To qualify, active participation at the conference (oral presentation or poster) will be required, and priority will be given to young scientists with financial constraints. Grants can be applied for at the time of registration, with a short motivation letter. More details will be given in the Second Circular.

\section{Local Organizing Committee}

Idoia Biurrun - Chair, idoia.biurrun@ehu.eus Asun Berastegi, aberastg@gan-nik.es Juan Antonio Campos, juanan.campos@ehu.eus Itziar García-Mijangos, itziar.garcia@ehu.eus Mercedes Herrera,meme.herrera@ehu.eus Javier Loidi, javier.loidi@ehu.eus

Javier Peralta, javier.peralta.de.andres@gmail.com Isabel Salcedo, isabel.salcedo@ehu.eus EDGG Conferences Coordinators

Didem Ambarlı, didem.ambarli@gmail.com Alla Aleksanyan, alla.alexanyan@gmail.com

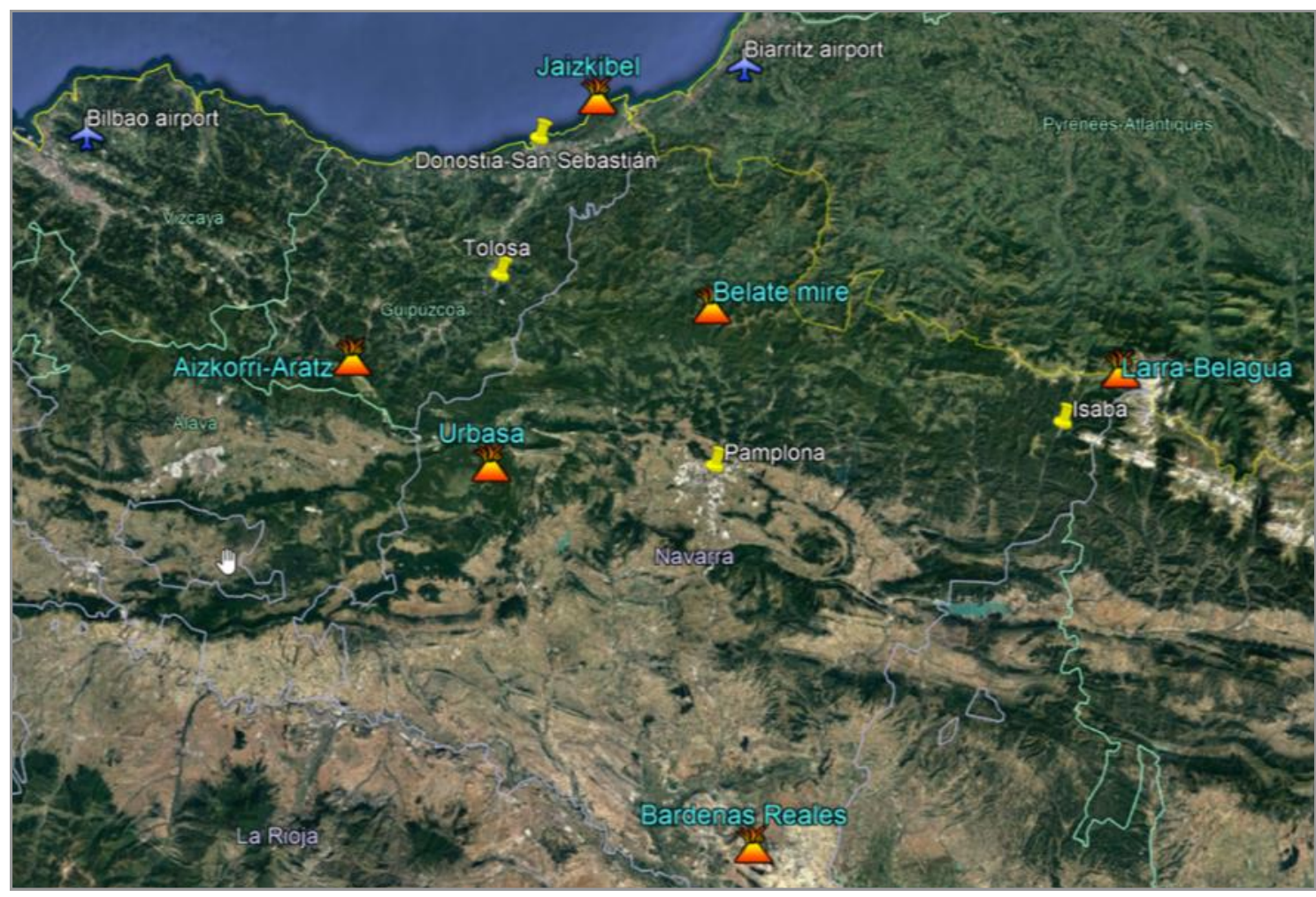

Fig. 9. Location of conference venue, main cities, accommodations and excursion sites. 


\section{Report on the International Symposium on Grassland Ecology and Conservation in Hohhot, Inner Mongolia, China}

An International Symposium on Grassland Ecology and Conservation took place in Hohhot, at the Inner Mongolia University (IMU), on August 21-23, 2019. It was jointly organised by the School of Ecology and Environment of the IMU and by regional branches of the China Association for Science and Technology, under the auspices of the Chinese Grassland Society, the Ecological Society of China and the Inner Mongolia Grassland Association.

The main topic of the Symposium was modelling, monitoring, sustainable use, conservation and management of grasslands (with special regard to natural steppes) through transdisciplinary and transnational cooperation. The Symposium included two keynote lectures and 40 talks and it was attended by 228 participants from seven countries, plus a number of students from the IMU (Figs. 1-2).

The talks included interesting studies on plot-based compositional data sampled from wet meadows within the ThreeRivers Headwater Region (Xilai Li, Quinghai University), from alpine grasslands of the Tibetan Plateau (Shikui Dong, Beijing Normal University; Wang Shiping, Institute of Tibetan Plateau of the Chinese Academy of Science) and from the steppes of Inner Mongolia (Frank Yonghong Li, IMU), Mongolia (Tuvshintogtokh Indree, Mongolian Academy of Science), Lake Baikal (Luliia Venteeva, Siberian branch of the Russian Academy of Science).

Riccardo Guarino, as EDGG representative, was invited to present "The EDGG activities on Palearctic grasslands: research, networking and passion for biodiversity", a talk aimed at summarizing the main outputs of the research

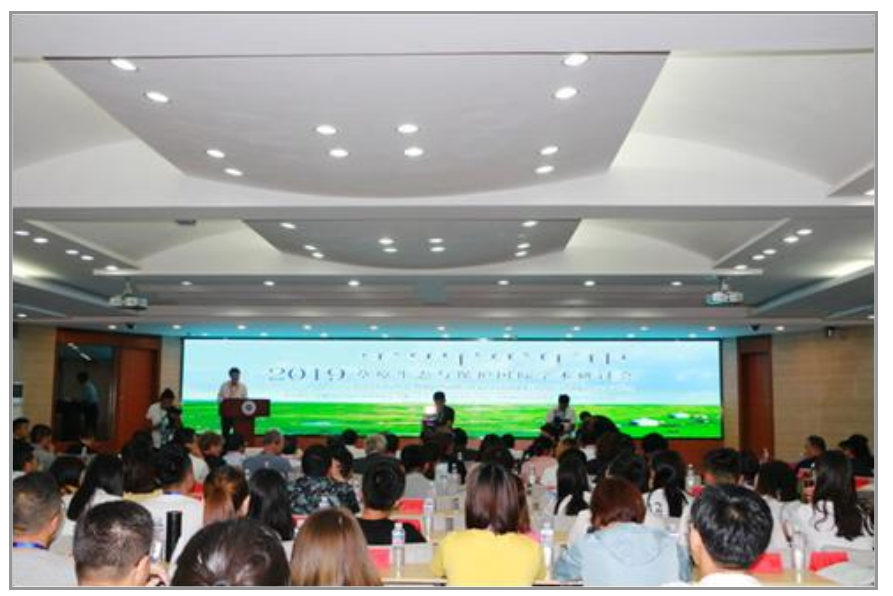

activities promoted by the EDGG. Many of the participants expressed an interest in the GrassPlot database and in the EDGG activities. It was agreed that invitations to join the EDGG will be sent out in order to support data sharing and to encourage new researchers from the West and Central Asian steppe regions to join the network.

In the afternoon of the second day symposium participants had the opportunity to visit two leading companies in their respective sectors: the Mengniu Dairy Company Ltd. and the Mengcao Eco-environment Company Ltd.

The first is one of the leading dairy product manufacturers in China, with an annual production capacity of 10.27 million tons (as of June 2019, http://www.mengniuir.com/ html/about profile.php); the second specializes in "grass, grassland and grass technology", coordinating many grassland and landscape restoration projects throughout China (Figs. 3-4, https://www.mengcao.com/\#page1/1).

At the end of the Symposium, a delegation of international guests, guided by Prof. Frank Yonghong Li, visited three outstanding sites in the surroundings of Xilinhot, a town about $600 \mathrm{~km}$ NE of Hohhot:

- Xilin Gol Biosphere Reserve. Established in 1987 as China's first grassland biosphere reserve, to protect the biodiversity of steppe ecosystems and to develop models for the sustainable use of grassland resources. The area measures $5,800 \mathrm{~km}^{2}$ and is extensively grazed by wild herbivores and domestic livestock (mainly horses, sheep and goats), managed by local herders. The main landmark of the area is a complex of flat-topped hills, formed by a lower layer of dark

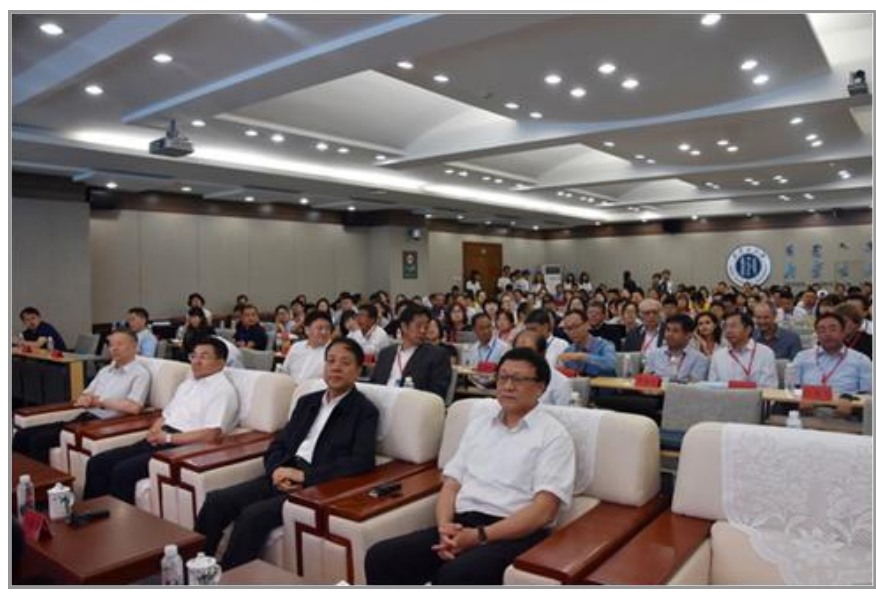

Figs. 1-2. The International Symposium on Grassland Ecology and Conservation (Hohhot, August 21-23, 2019) was attended by 228 people from seven countries. Photos: F. Yonghong Li. 

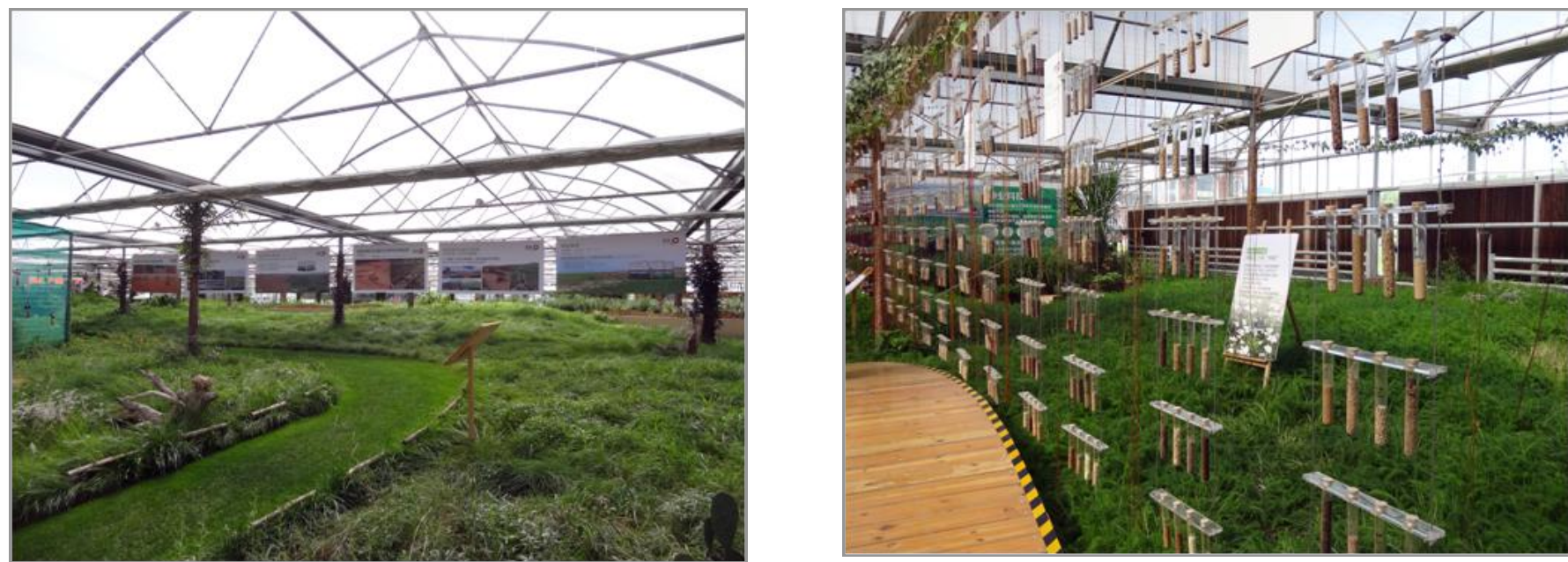

Figs. 3-4. Working with grasslands: the Grassland Museum at the Mengcao Eco-environment Company Ltd. Photos: R. Guarino.

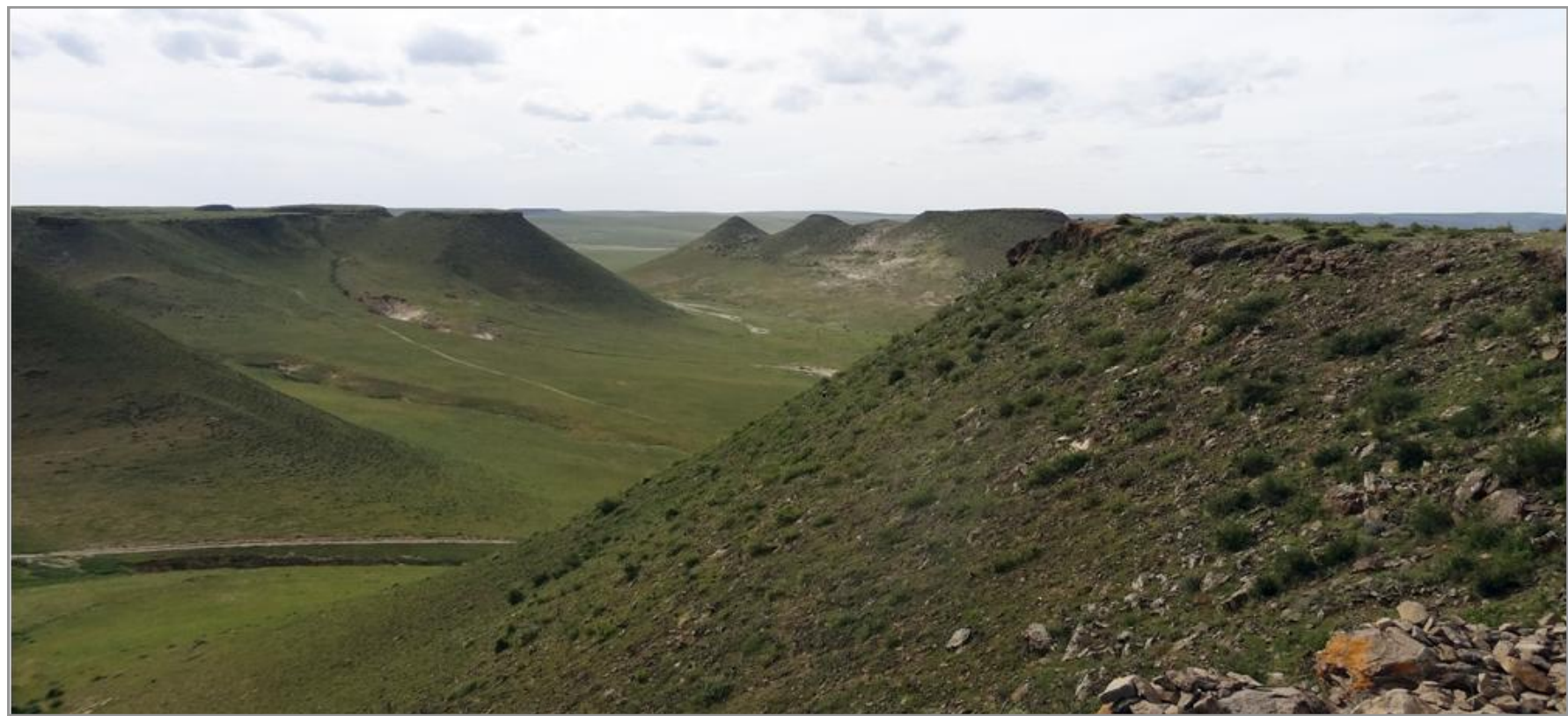

Fig. 5. The flat-topped hills of the Xilin Gol volcanic landscape merge with the horizon line. Hillsides are covered with scattered fallen stones from the basaltic interbeds. Photo: R. Guarino.
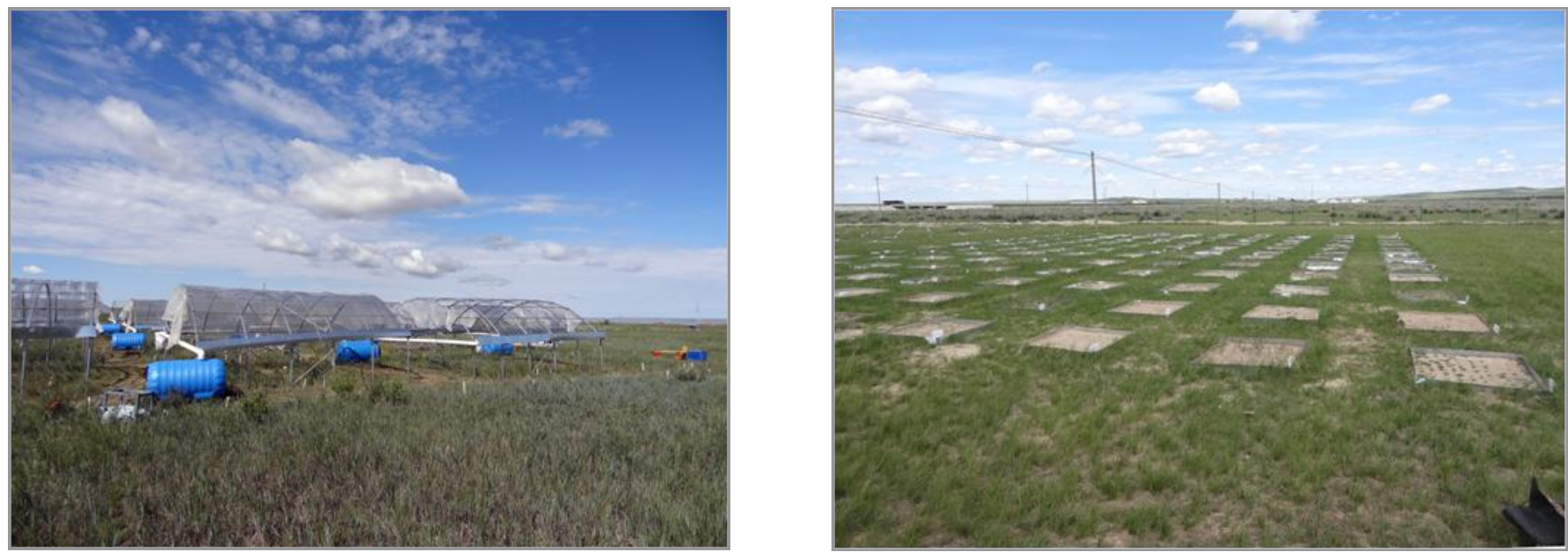

Figs. 6-7. Plants for the experimental manipulation of water and temperature (left) and of nitrogen availability at the Grassland Ecosystem Research Station of Inner Mongolia University. Photos: R. Guarino. 


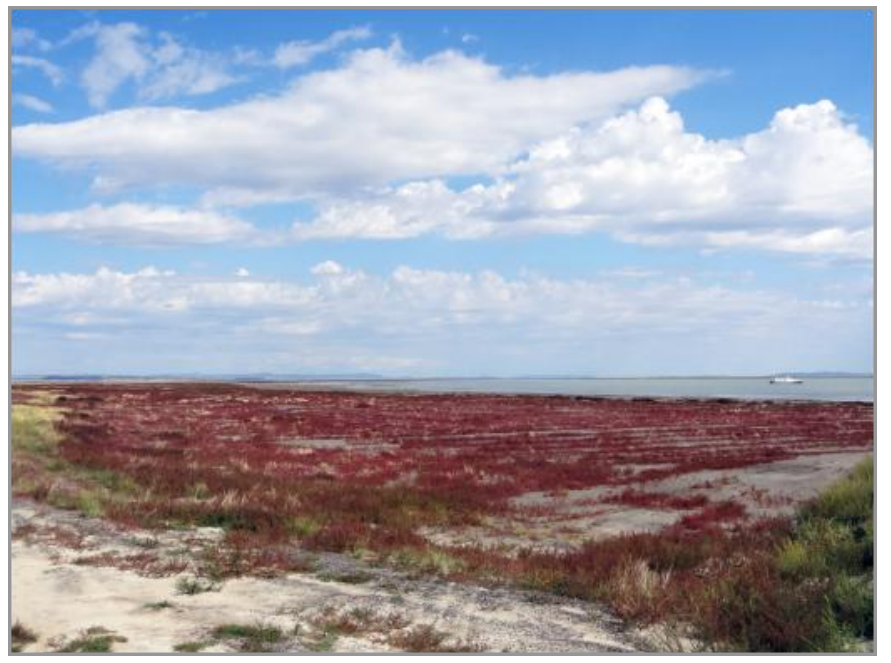

Fig. 8. The Dalinor Lake is a typical saline-alkaline lake, surrounded by a belt of succulent chenopods (Suaeda glauca). Photo: R. Guarino.

sandstone and conglomerate, with interbeds of basalts, and an upper layer of conglomerate and white volcanic ash (Fig. 5).

- The Grassland Ecosystem Research Station of Inner Mongolia University. Extensive areas of gently swaying grasslands under intense blue skies are not just a charming view, but also an ideal living laboratory for grassland ecologists. The Grassland Ecosystem Research Station, located in the typical steppe region on the Mongolian Plateau $\left(44^{\circ} 10^{\prime} \mathrm{N}\right.$, $116^{\circ} 28^{\prime} \mathrm{E}, 1100 \mathrm{~m}$ a.s.l.), is the field research base of the School of Ecology and Environment (IMU), headed by Prof. Frank Yonghong Li. The facilities at the research station include two lysimeter systems for investigating single species and/or grassland responses under different regimes of temperature, $\mathrm{CO}_{2}$ concentration, water and nutrient availability, grazing pressure, and seed predation (Figs. 6-7). The semiarid continental climate of this area is characterized by a mean (1998-2013) precipitation of $253 \mathrm{~mm}$ and a mean temperature of $13.8^{\circ} \mathrm{C}$ during grassland growth season (April to August), coincident with the maximum rainfall.

- Dalinor Nature Reserve. In the Mongolian language, Dalinor means "lake like the sea" and it is one of the four largest lakes of IM (Fig. 8). The maximum depth of the lake is only $13 \mathrm{~m}$, but it covers an area of $228 \mathrm{~km}^{2}$ and has a water (brackish) volume of 1.6 billion $\mathrm{m}^{3}$. Its northwest shore features the Dalinor volcanic landscape, which includes a basalt plateau and scattered volcanic necks (Fig. 9), which once were islands in the lake when water levels were higher. The area is part of the Heshingten Global Geopark, located at the junction of Daxing'anlig Mts., Yanshan Mts. and the Hunshandake Sandland. The Geopark covers $1,750 \mathrm{~km}^{2}$ and is made up of unique geological, glacial, geothermal and volcanic structures, lakes, marshes, grasslands, deserts and sites of cultural heritage. Its grasslands are the most species rich of IM as the Heshingten is at the convergence zone of the northeast Chinese Mongolian floras.

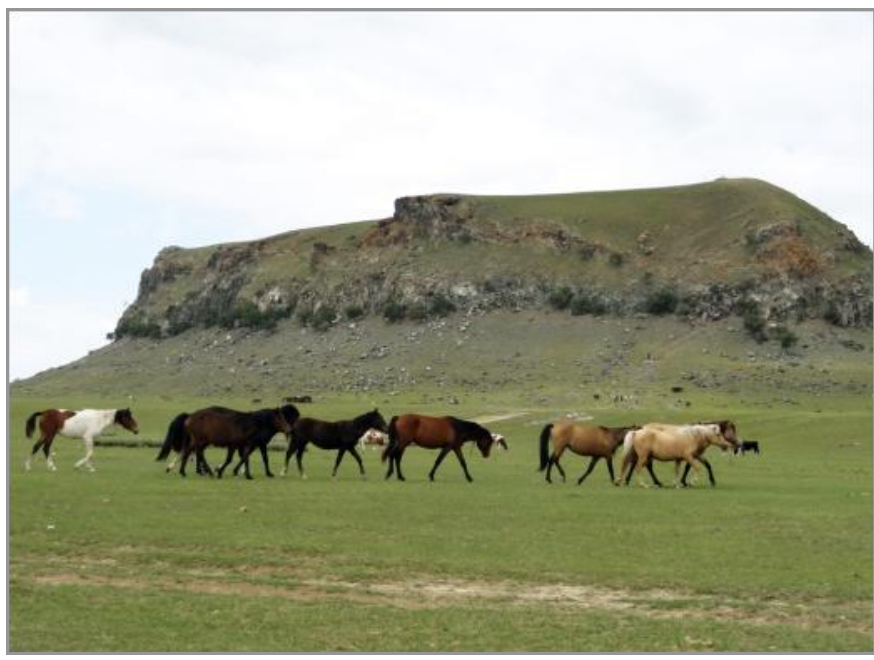

Fig. 9. The Zenzi hill (anvil-shaped hill) is a volcanic neck whose current morphology results by the weathering and lakewater erosion. Photo: R. Guarino.

With the assistance of Frank Yonghong Li, Tiejun Bao, Hugjiltu Minggagud, and Jinghui Zhang, a demonstration of the EDGG biodiversity sampling approach was carried out using $10 \mathrm{~m}^{2}$ nested plots (Fig. 10; Table 1). The EDGG hopes that these three plots are the start of a period of greater engagement with research in Central Asia, an area with the largest expanses of grassland in the Palaearctic region. The EDGG also hopes that the International Symposium on Grassland Ecology and Conservation will mark the start of a fruitful scientific cooperation with colleagues from China and neighbouring countries.

Riccardo Guarino, Palermo, Italy guarinotro@hotmail.com

Frank Yonghong Li, Hohhot, China lifyhong@126.com

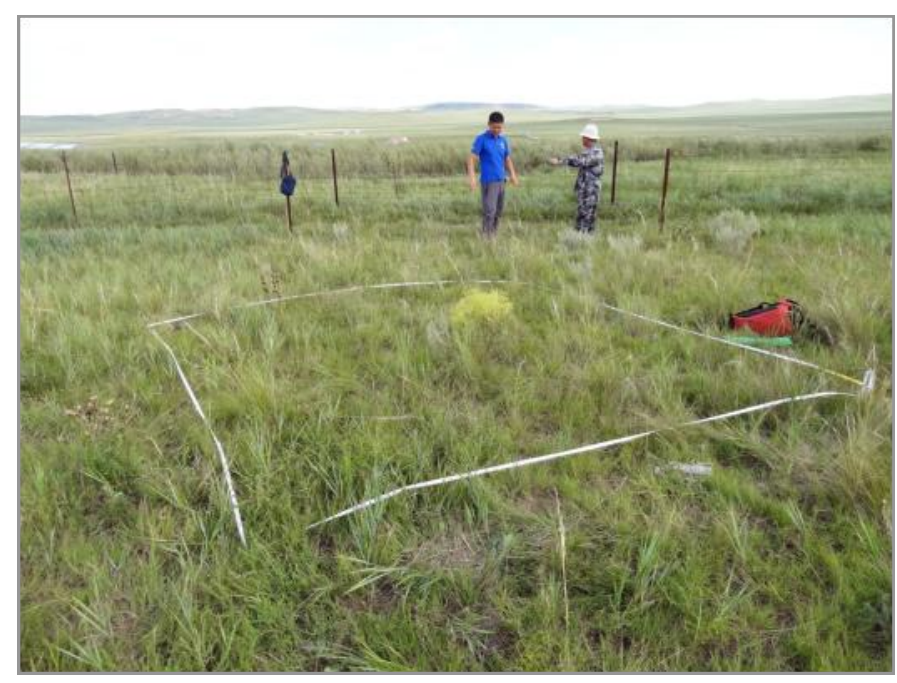

Fig. 10. Sampling a $10 \mathrm{~m}^{2}$ nested plot in a dry steppe dominated by Leymus chinensis and Cleistogenes squarrosa. Photo: R. Guarino. 
Table 1. Three nested plots (sampled on August 24, 2019) in dry steppes of IM. Cover values were estimated on the $10 \mathrm{~m}^{2}$ plot. Cover values $\geq 10 \%$ are in bold character. Taxonomic nomenclature according to the Flora of China (http:// www.efloras.org/flora page.aspx?flora id=2).

Protocol by: Riccardo Guarino. Other authors: Frank Yonghong Li, Tiejun Bao, Hugjiltu Minggagud, Jinghui Zhang.

\begin{tabular}{|c|c|c|c|c|c|c|}
\hline Plot nr. & \multicolumn{2}{|l|}{1} & \multicolumn{2}{|l|}{2} & \multicolumn{2}{|l|}{3} \\
\hline Latitude (precision: $5 \mathrm{~m}$ ) & \multicolumn{2}{|c|}{$44^{\circ} 15^{\prime} 59^{\prime \prime}$} & \multicolumn{2}{|c|}{$44^{\circ} 15^{\prime} 50^{\prime \prime}$} & \multicolumn{2}{|c|}{$43^{\circ} 33^{\prime} 20^{\prime \prime}$} \\
\hline Longitude (precision: $5 \mathrm{~m}$ ) & \multicolumn{2}{|c|}{$116^{\circ} 31^{\prime} 29^{\prime \prime}$} & \multicolumn{2}{|c|}{$116^{\circ} 31^{\prime} 13^{\prime \prime}$} & \multicolumn{2}{|c|}{$116^{\circ} 40^{\prime} 13^{\prime \prime}$} \\
\hline Corner of GPS & \multicolumn{2}{|l|}{ NW } & \multicolumn{2}{|l|}{ NW } & \multicolumn{2}{|c|}{ NW } \\
\hline Elevation $(\mathrm{m})$ & \multicolumn{2}{|l|}{1143} & \multicolumn{2}{|l|}{1140} & \multicolumn{2}{|l|}{1278} \\
\hline Aspect & \multicolumn{2}{|l|}{$178^{\circ} \mathrm{S}$} & \multicolumn{2}{|l|}{-} & \multicolumn{2}{|l|}{$328 \mathrm{NW}$} \\
\hline Inclination & \multicolumn{2}{|l|}{$2^{\circ}$} & \multicolumn{2}{|l|}{$0^{\circ}$} & $2^{\circ}$ & \\
\hline Relief position & plain & & plain (slightly ho & wed) & tophill & \\
\hline Max. microrelief $(\mathrm{cm})$ & 2 & & 5 & & 3 & \\
\hline Vegetation height $(\mathrm{cm})$ & $20,5,8,12$ & & $20,13,13,15$ & & $20,15,31,1$ & \\
\hline Vegetation cover (total) & $80 \%$; max. heigh & $50 \mathrm{~cm}$ & $85 \%$; max. height & $08 \mathrm{~cm}$ & 85\%; max. height & $10 \mathrm{~cm}$ \\
\hline Litter cover (total) & $10 \%$ & & $20 \%$ & & $40 \%$ & \\
\hline & Edge lenght $(\mathrm{m})$ & Cover (\%) & Edge lenght $(\mathrm{m})$ & Cover (\%) & Edge lenght $(\mathrm{m})$ & Cover (\%) \\
\hline Achnatherum sibiricum & & & & & 0.01 & 50 \\
\hline Adenophora stenanthina & & & & & 3.16 & 1 \\
\hline Agropyron cristatum & 3.16 & 3 & & & & \\
\hline Allium anisopodum & 0.10 & 4 & & 0.5 & 0.10 & 0.8 \\
\hline Allium senescens & & & & & 0.32 & 3 \\
\hline Allium tenuissimum & & & & & 1.00 & 0.2 \\
\hline Artemisia commutata & 1.00 & 1 & & & 1.00 & 0.8 \\
\hline Artemisia frigida & & & 3.16 & 3 & & \\
\hline Artemisia scoparia & 3.16 & 1 & & & 3.16 & 0.8 \\
\hline Artemisia sieversiana & & & 3.16 & 0.8 & 3.16 & 0.8 \\
\hline Astragalus galactites & & & 3.16 & 0.5 & 3.16 & 0.3 \\
\hline Caragana microphylla & & & & & 3.16 & 1 \\
\hline Carex duriuscula & & & 3.16 & 2 & & \\
\hline Carex korshinskyi & & & & & 1.02 & 2 \\
\hline Carpesium abrotanoides & 3.16 & 0.1 & & & & \\
\hline Chenopodium acuminatum & & & 0.32 & 0.5 & & \\
\hline Chenopodium glaucum & 1.00 & 0.1 & 0.32 & 0.5 & & \\
\hline Cleistogenes squarrosa & 0.01 & 45 & 0.01 & 50 & 1.00 & 5 \\
\hline Dontostemon micranthus & & & & & 1.03 & 0.2 \\
\hline Euphorbia esula & & & & & 0.32 & 0.3 \\
\hline Festuca dahurica & & & & & 1.01 & 3 \\
\hline Heteropappus altaicus & & & 3.16 & 1 & & \\
\hline $\begin{array}{l}\text { Klasea centauroides (= Serratula centaur- } \\
\text { oides) }\end{array}$ & & & & & 3.16 & 0.3 \\
\hline Koeleria macrantha s.l. (= K. cristata) & & & & & 3.16 & 0.8 \\
\hline Leymus chinensis & 0.01 & 35 & 0.32 & 5 & 0.32 & 0.2 \\
\hline Oxytropis hirta & 3.16 & 2 & & & & \\
\hline Pholomis umbrosa & & & 3.16 & 2 & & \\
\hline Poa attenuata & & & & & 1.05 & 0.5 \\
\hline Potentilla bifurca & & & & & 0.10 & 5 \\
\hline Potentilla tanacetifolia & 3.16 & 0.8 & & & & \\
\hline Potentilla verticillaris & & & & & 3.16 & 0.5 \\
\hline Rhaponticum chinense & & & 1.00 & 2 & & \\
\hline Salsola collina & 0.32 & 2 & 0.01 & 10 & 1.00 & 0.3 \\
\hline Saposhnikovia divaricata & & & 3.16 & 4 & & \\
\hline Stellera chamaejasme & & & & & 1.04 & 0.5 \\
\hline Stipa grandis & 1.00 & 2 & & & 0.03 & 40 \\
\hline Stipa sareptana var. krylovii & & & 3.16 & 8 & & \\
\hline Thalictrum petaloideum & 0.03 & 3 & 1.00 & 1 & & \\
\hline Thalictrum squarrosum & & & & & 3.16 & 1 \\
\hline
\end{tabular}

\section{NOTES:}

Plots 1-2: Location: Maodeng. Parental geological substrate: sand, without any visible stone/rock (soil depth $>90 \mathrm{~cm}$ ); Land use: Heavily grazed until 2013, now unmanaged.

Plot 3: Location: Gegenshala. Parental geological substrate: sand, without any visible stone/rock (soil depth $>90 \mathrm{~cm}$ ); Land use: Grazed until 1998, now unmanaged. 


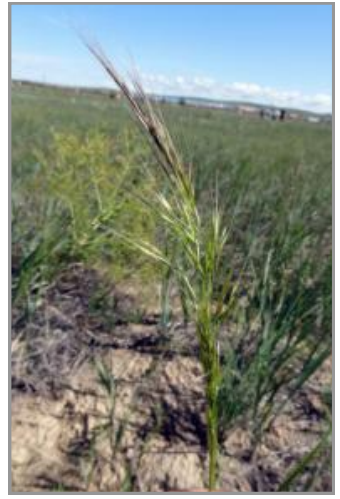

Achnatherum sibiricum

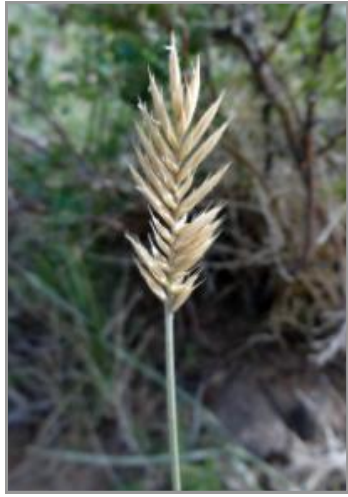

Agropyron cristatum

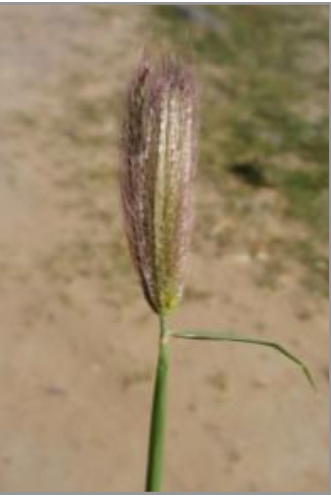

Chloris virgata

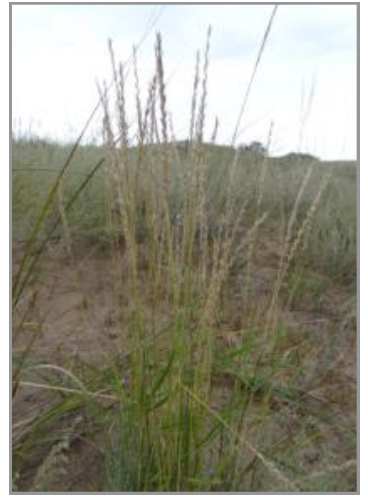

Psammochloa villosa

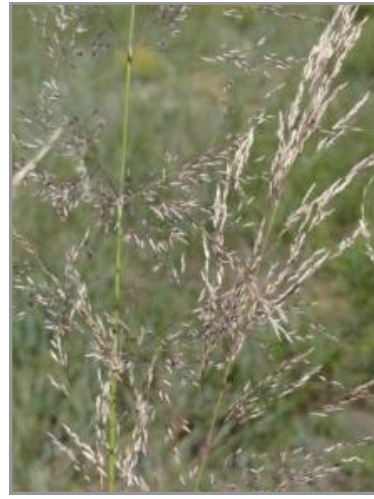

Stipa splendens

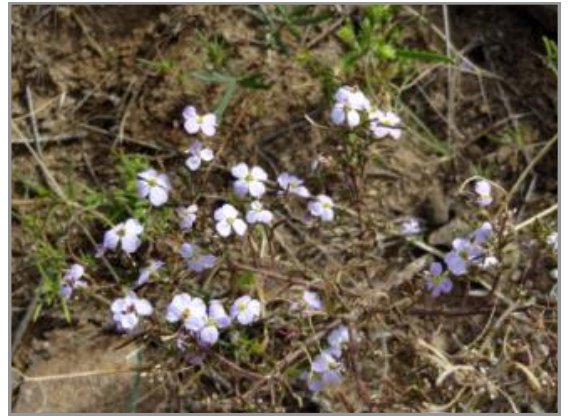

Cymbaria daurica

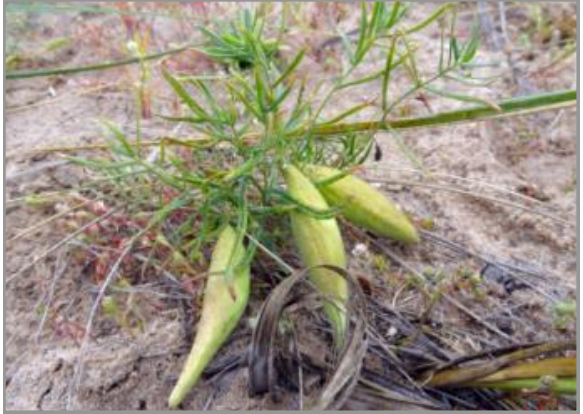

Cynanchum thesioides

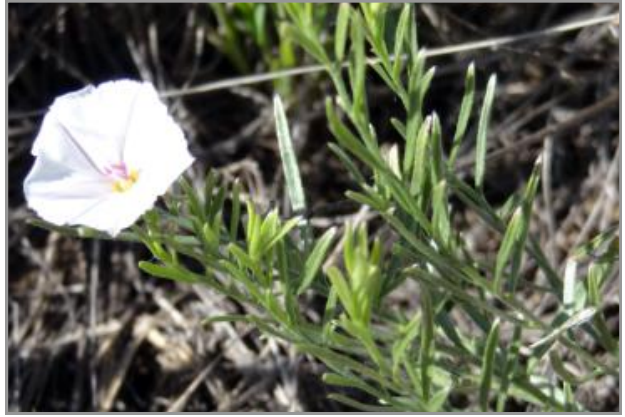

Convolvulus ammannii

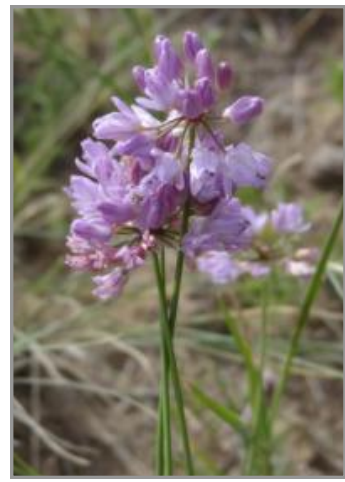

Allium tenuissimum

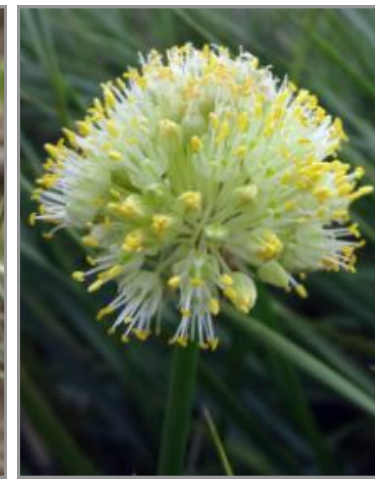

Allium condensatum

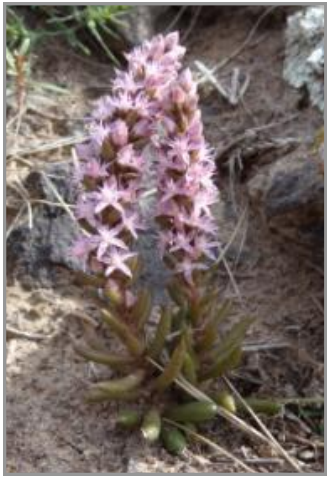

Orostachys fimbriata

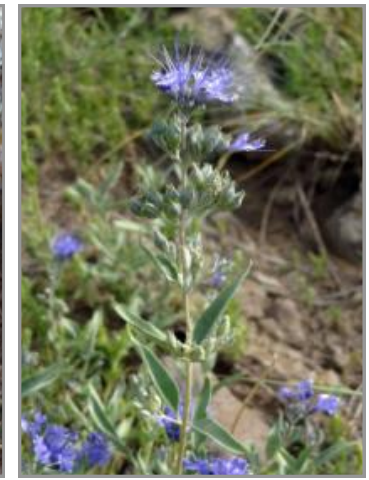

Caryopteris mongolica

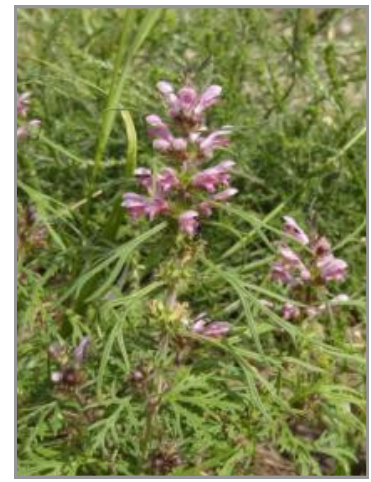

Leonurus sibiricus

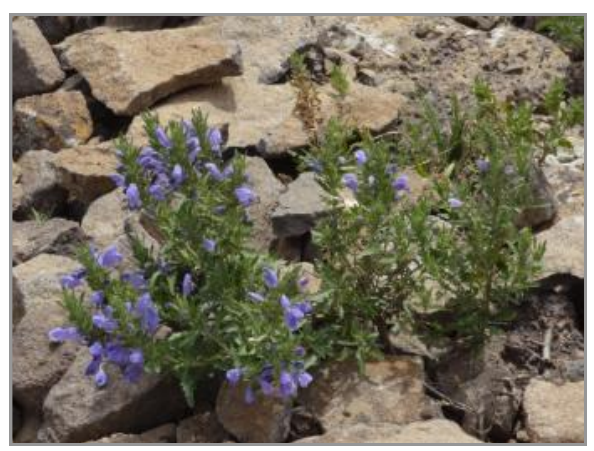

Dracocephalum moldavica

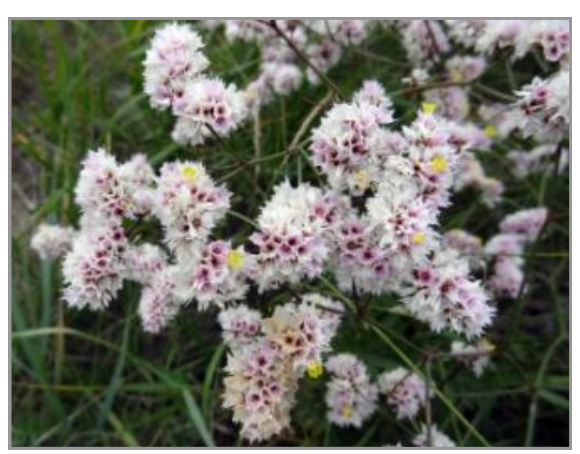

Limonium bicolor

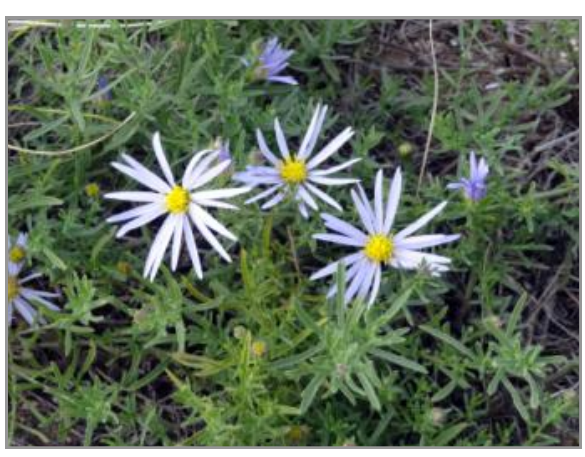

Heteropappus altaicus

Some grassland plant species of Inner Mongolia. Photos: R. Guarino. 


\section{EDGG Publication}

\section{The $5^{\text {th }}$ EDGG-edited Special Feature in Hacquetia is published}

The fifth Special Feature edited by EDGG (eds. O. Valkó, S. Venn, R. Labadessa, S. Palpurina, S. Burrascano \& A. Ushimaru) in the journal Hacquetia is available online (https:// content.sciendo.com/view/journals/hacq/18/2/ hacq.18.issue-2.xml) and in paper. The special feature was initiated by members of the EDGG attending the 15th Eurasian Grassland Conference (EGC) in Sulmona, Italy in June 2018. The papers in this special issue cover a wide range of grassland ecosystems from mountain dry grasslands to lowland loess grasslands, feathergrass steppes and wet grasslands, and focus on the biodiversity values and conservation issues of Palaearctic grasslands. We believe that this compilation will contribute to a better understanding of the ecology of grasslands and support their more effective conservation. The special issue contains five research papers from Greece (Tsiobani et al. 2019), Hungary (Deák et al. 2019, Tóth et al. 2019), Switzerland (Dengler et al. 2019a) and Ukraine (Polchaninova et al. 2019). The Special Feature also includes a report of the EDGG activities in 2018 and 2019 (Dengler et al. 2019b) and an editorial paper (Valkó et al. 2019).

\section{References}

Deák, B., Tóth, C., Bede, Á., Apostolova, I., Bragina, T.M., Báthori, F. \& Bán, M. 2019. Eurasian Kurgan Database - a citizen science tool for conserving grasslands on historical sites. Hacquetia 18 (2): 185-193.

Dengler, J., Widmer, S., Staubli, E., Babbi, M., Gehler, J., Hepenstrick, D., Bergamini, A., Billeter, R., Boch, S., Rohrer, S. \& Dembicz, I. 2019a. Dry grasslands of the central valleys of the Alps from a European perspective: the example of Ausserberg (Valais, Switzerland). Hacquetia 18 (2): 161-183.

Dengler, J., Aleksanyan, A., Ambarlı, D., Biurrun, I., Dembicz, I., Kuzemko, A., Török, P., Venn, S. \& Vrahnakis, M. 2019b. The Eurasian Dry Grassland Group (EDGG) in 2018-2019. Hacquetia 18(2): 153-160

Polchaninova, N., Savchenko, G., Ronkin, V., Drogvalenko, A. \& Putchkov, A. 2019. Summer fire in steppe habitats: long-term effects on vegetation and autumnal assemblages of cursorial arthropods. Hacquetia 18 (2): 219-237.

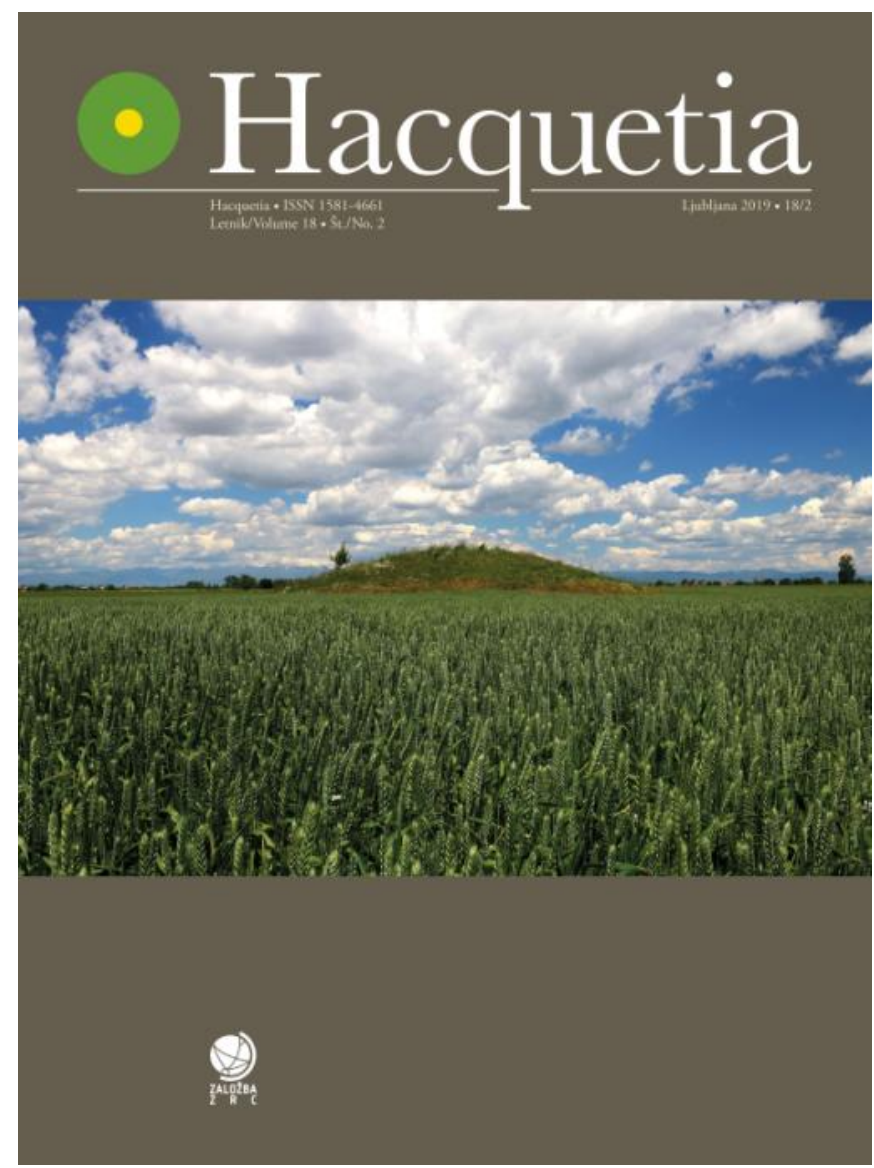

Tóth, Cs. A., Deák, B., Nyilas, I., Bertalan, L., Valkó, O. \& Novák, T. 2019. Iron age burial mounds as refugia for steppe specialist plants and invertebrates - case study from the Zsolca mounds (NE Hungary). Hacquetia 18 (2): 195-206.

Tsiobani, E. T., Yiakoulaki, M. D. \& Menexes, G. 2019: Seasonal variation in water buffaloes' diet grazing in wet grasslands in Northern Greece. Hacquetia 18 (2). 207-218.

Valkó, O., Labadessa, R., Palpurina, S., Burrascano, S., Ushimaru, A. \& Venn, S. 2019. Conservation and diversity of Palaearctic grasslands - Editorial to the 5th EDGG special issue in Hacquetia. Hacquetia 18(2): 149-152. 


\section{EDGG Publication}

\section{Call for contributions to the new EDGG-edited Special Feature in Hacquetia}

\begin{abstract}
6th EDGG Special Feature in Hacquetia 2021: Fauna, flora, vegetation and conservation of Palaearctic natural and semi-natural grasslands
\end{abstract}

This is the first call for the submission of manuscripts for the EDGG-edited Special Feature in Hacquetia 2021. We welcome manuscripts about natural and semi-natural grasslands, on all taxa and from any region in the Palaearctic realm (Europe; West, Central and North Asia; North Africa).

Hacquetia (http://www.degruyter.com/view/i/hacq) is the international journal of the Biological Branch of the Slovenian Academy of Sciences. It appears in two issues per year, both in print and online. Through offering longer articles, open access publication and free reproduction of colour figures, it is a very attractive publication venue. Currently it is indexed in the Scopus and BIOSIS literature databases, and it is likely to be included in the Web of Science in the near future (aided by our very international and high-quality Special Issues and your citations of these).

This Special Issue will be the 6th EDGG-edited Special Issue in Hacquetia, following the five successful issues in 2014/1, 2015/1, 2016/2, 2018/1 and 2019/2. This Special Issue will appear as the first issue of 2021, to be published approximately in January 2021, with about 150-250 pages reserved for our articles. It will also contain a report on the EDGG activities of the previous year.

\section{Procedure and deadlines:}

The deadline for full-text submission is 15 January 2020 and manuscripts will undergo the normal peer-review process. If you are interested in contributing a manuscript for this comprehensive Special Issue, then please contact the Chair of the editorial team (see below) and submit your manuscript to her. Author guidelines can be found at the journal homepage: http://www.degruyter.com/view/i/hacq.

\section{Guest Editor Team:}

Orsolya Valkó (Hungary, https://scholar.google.com/ citations?user=PwD4cKcAAAAJ\&hl=en)

Stephen Venn (Finland, https://scholar.google.com/ citations?user=|AbbyQEAAAAJ\&hl=en)

Sabina Burrascano (Italy, https://scholar.google.it/citations? user=AvtMXBsAAAAJ\&hl=en)

Salza Palpurina (Bulgaria, https://scholar.google.cz/ citations?user=ysyBXvUAAAAJ\&hl=en)

Rocco Labadessa (Italy, https://scholar.google.com/ citations?hl=uk\&user=U3xcHeYAAAAJ)

Atushi Ushimaru (Japan, https://scholar.google.com/ citations?user=9uEOIWMAAAAJ\&hl=en)

Contact for questions and submission of manuscripts (Chair of the Guest Editors):

Orsolya Valkó, Debrecen Hungary valkoorsi@gmail.com

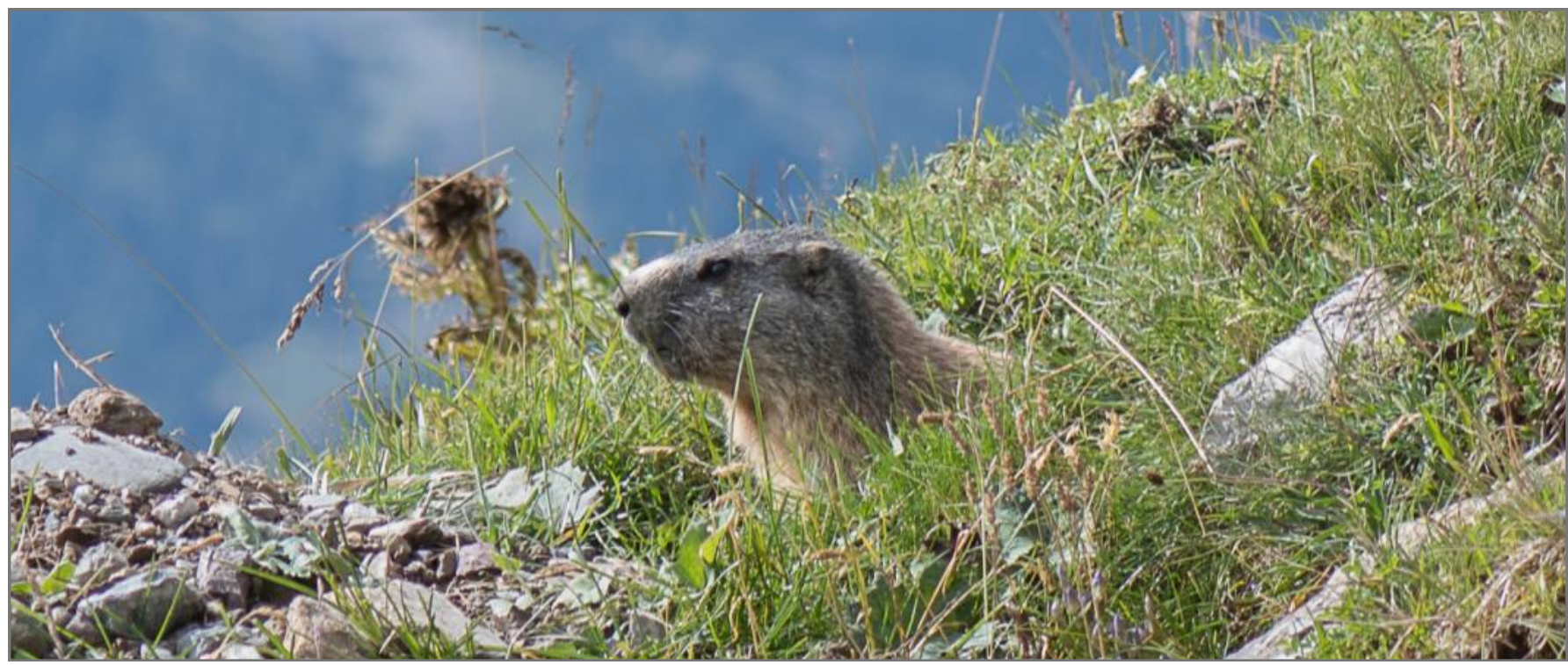

Alpine marmot (Marmota marmota) sitting at the entrance of its burrow in an alpine meadow in the Upper Engadine, Switzerland. Photo: J. Dengler. 


\section{EDGG Publication}

\section{Call for the 15th EDGG-edited Special Feature in Tuexenia: Sustainability of Central European semi- natural grasslands - traditional land use, management and biodiversity}

For the fifteenth time EDGG organises a Grassland Special Feature in Tuexenia (http://www.tuexenia.de), a respected journal focused on geobotany, vegetation ecology and related applied sciences. The Special Feature is open to all EDGG members and particularly welcomes contributions that were presented on the Eurasian Grassland Conference 2019 and contributions with results from the EDGG Field Workshops. If you want to contribute, you are requested to send an abstract to Steffen Boch till 31 October 2019. Based on these abstracts, we will decide which papers to invite. If you have published in previous EDGG Special Features in Tuexenia, you could also directly submit the full paper without previous abstract evaluation, but you risk that then all "slots" are already filled. First-time authors in the Tuexenia Special Feature need to send an abstract first in any case.

As usual, contributions on flora and vegetation of Central European grasslands as well as their conservation and restoration are welcome. Central Europe is defined following Wikipedia (https://en.wikipedia.org/wiki/Central Europe) as consisting of Germany, Switzerland, Liechtenstein, Austria, Slovenia, Hungary, Slovakia, Czech Republic and Poland. Contributions of adjacent regions are also welcome if they make a clear connection to Central Europe, at least in the discussion part. Tuexenia is a geobotanical journal, thus the focus is on flora and vegetation. However, complex studies involving both vegetation and animals are also highly welcome.

All manuscripts are subject to peer review and should be submitted preferentially until $\mathbf{3 0}$ November 2019 and then have a good chance of inclusion in the next Special Feature expected for July 2020. Later submission is only possible after prior consultation with the Chair of Guest Editors (Steffen Boch). The earlier you submit, the larger is the chance that your paper will be accepted in time for the 2020 Special Feature. Those manuscripts that are accepted too late or at a point of time when already all "slots" are filled will be transferred to the 2021 Special Feature.

Benefits of submitting to our Special Feature in Tuexenia include:

- Indexed in the Web of Science and Scopus

- 2018 Impact Factor (1.267), CiteScore (1.00)

- Full colour and open access

- No page charges

- Competent and sympathetic Guest Editor Team: Steffen Boch (chair, Switzerland), Thomas Becker (Germany), Balázs Deák (Hungary), Jürgen Dengler (Switzerland), Viktoria Wagner (Canada).

Steffen Boch, Birmensdorf, Switzerland steffen.boch@wsl.ch

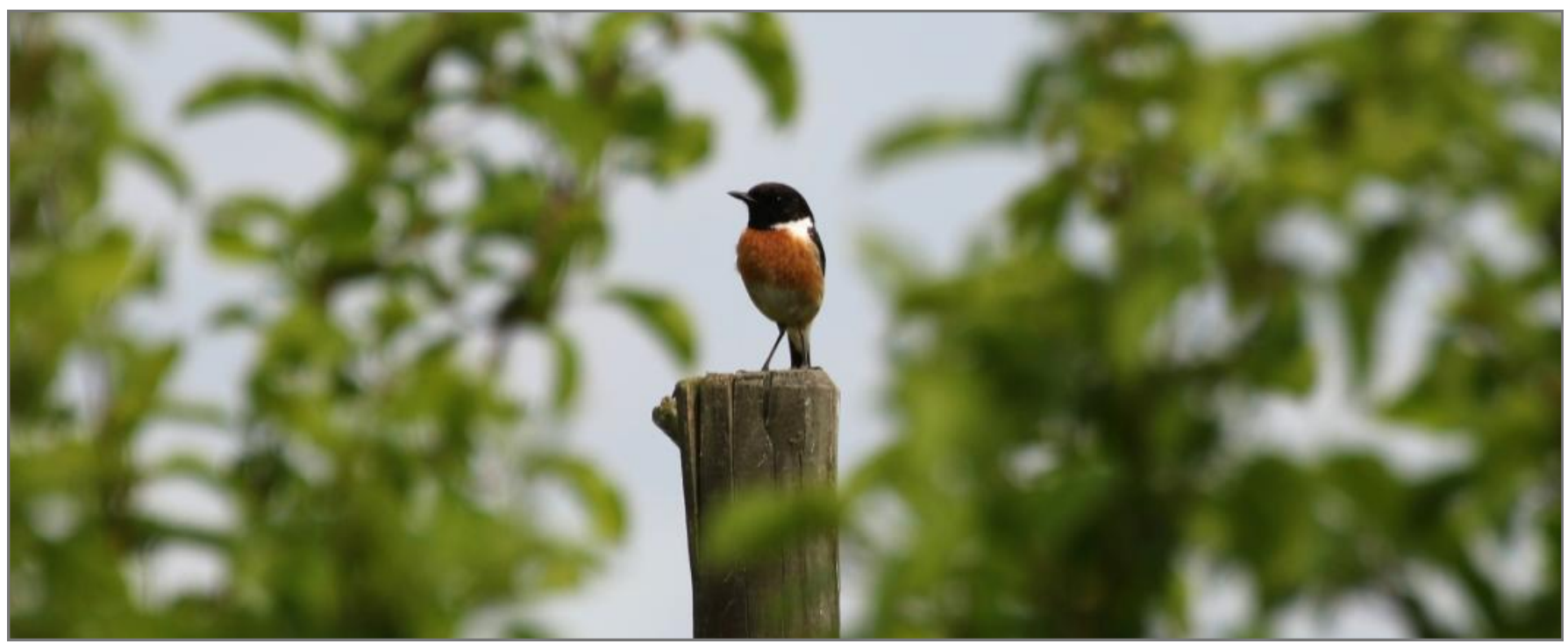

Stonechat (Saxicola rubicola) at a hedge of a lowland hay meadow, Fürstenfeld, East-Styria, Austria. Photo: P. Sengl. 


\section{EDGG Publication}

\section{Call for the Special Feature on the topic of "The Sus- tainable Management of Grasslands for the Conserva- tion of Biodiversity"}

The EDGG plans to produce this SF in either Sustainability Science (IF 4.669) or Landscape Ecology (IF 4.349), though the procedures of these journals require that we first provide a proposal with full details of the proposed contributions, after which they will decide whether to accept our proposal or not. This initiative arose out of discussions on the topic during the $16^{\text {th }}$ Eurasian Grassland Conference, in Graz. The coordinator of the project is Stephen Venn and the other members of the team working on this SF are: Andrea Catorci, Monika Janišová, Jacqueline Loos, Zsolt Molnár, Luis Silva, Vicky Temperton and Jianshuang Wu. The success of this proposal will depend on the number and quality of the proposed contributions, so I hope that many of you will consider submitting an abstract on a relevant topic. Please note that review/synthesis/perspective papers are particularly encouraged. Please send your abstracts, including title, list of contributing authors/affiliations and estimated time of completion of the manuscript, to Stephen.venn@helsinki.fi as soon as possible. The deadline for submission of abstracts is 20 October 2019. If you need more time or have other queries, then please contact me.

Stephen Venn, Helsinki, Finland Stephen.venn@helsinki.fi

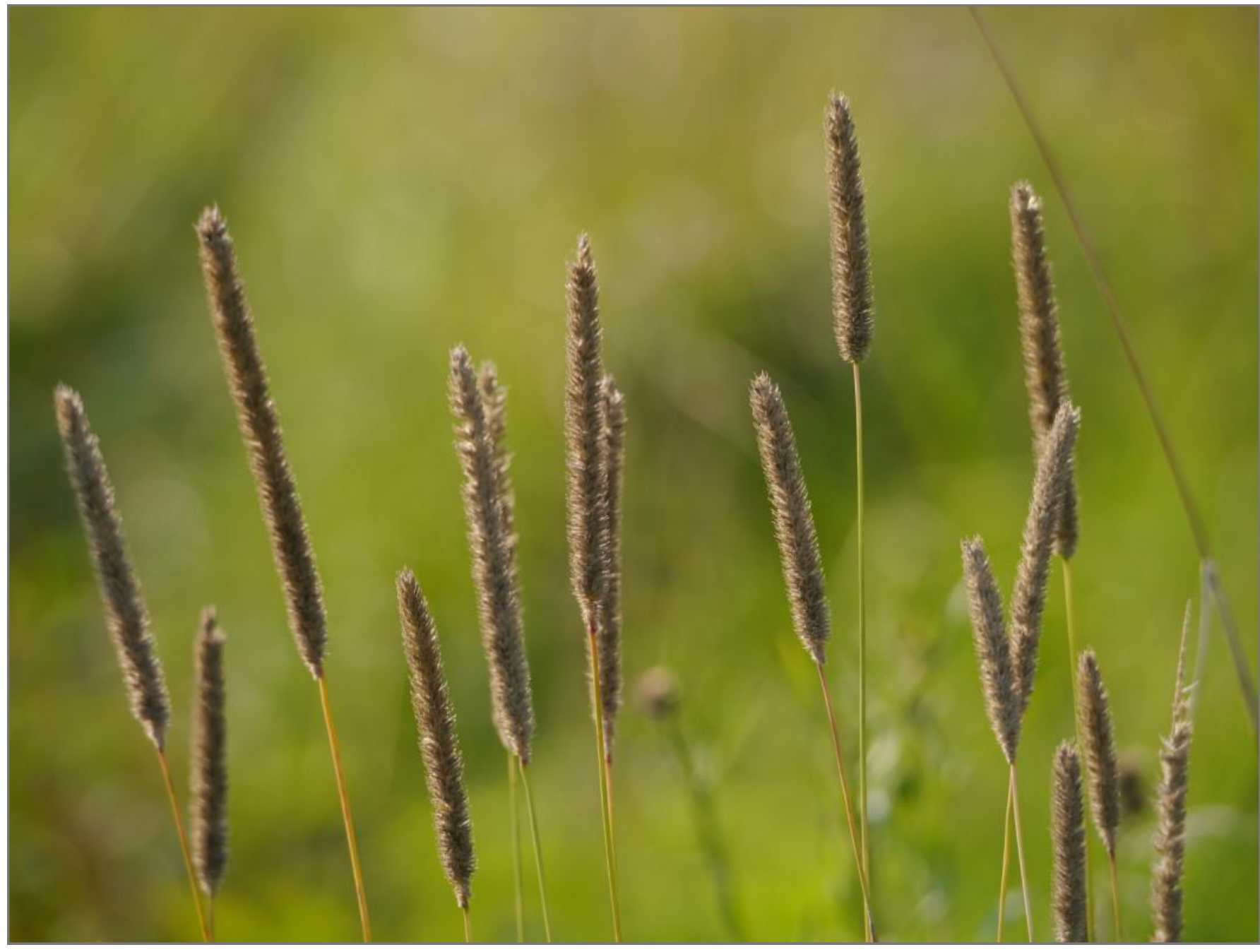

Phleum pratense, near Budzyń, Poland. Photo: I. Dembicz. 


\title{
Alpine grassland vegetation at Gornergrat (Canton of Valais, Switzerland): Vegetation mapping for environ- mental planning
}

\author{
Jonathan Pachlatko $^{1^{*}}$, Martin Wyttenbach ${ }^{1}$, \& Jürgen Dengler ${ }^{1,2,3}$ (C)
}

\begin{abstract}
${ }^{1}$ Institute of Natural Resource Sciences (IUNR), Zurich University of Applied Sciences (ZHAW), Grüentalstr. 14, 8820 Wädenswil, Switzerland; jonathan pachlatko@zhaw.ch (J. Pachlatko), martin.wyttenbach@zhaw.ch (M. Wyttenbach), juergen.dengler@zhaw.ch (J. Dengler)

${ }^{2}$ Plant Ecology, Bayreuth Center of Ecology and Environmental Research (BayCEER), University of Bayreuth, Universitätsstr. 30, 95447 Bayreuth, Germany; juergen.dengler@uni-bayreuth.de
\end{abstract}

\author{
${ }^{3}$ German Centre for Integrative Biodiversity Research (iDiv) Halle-Jena- \\ Leipzig, Deutscher Platz 5e, 04103 Leipzig, Germany \\ *) Corresponding author jonathan pachlatko@zhaw.ch
}

Palaearctic Grasslands 43 (2019): 23-37

Abstract: Alpine landscapes are increasingly used by tourism. At the highly frequented Gornergrat in Switzerland there was a need to develop a concept to demerge the paths of hikers and mountain bikers and thus enable a conflict-free use for all user groups. The present study aimed at providing vegetation maps of the sensible areas at Gornergrat to derive recommendations for the planning and restoration of the new trail network. For this purpose, we sampled 32 vegetation plots $\left(10 \mathrm{~m}^{2}\right)$. These were then subjected to TWINSPAN classification, and the derived five units characterized by their diagnostic species based on standardized phi-values. We used ANOVA to test for differences of these units with regard to environmental parameters. The five distinguished vegetation units were assigned to syntaxa down to the alliance level. Finally, a mapping key was derived from the synoptic table to allow the delimitation of units in the field, which resulted in two vegetation maps. We found protected habitats and vascular plant species, as well as a species of the Red List of vascular plants in the study area. Especially at the Riffel Lake, the area has striking disturbances of vegetation due to trampling, which has increased significantly in the last 30 years. For the Gornergrat concept we thus recommend (i) to make the disturbed vegetation at the eastern lake shore inaccessible to visitors, (ii) to restore this part with low-intensity measures and (iii) not to lead the planned new changes through sensitive areas (snow beds and fens).

Keywords: alpine grassland; environmental planning; Gornergrat; hiking trail; mountain bike trail; recreational use; restoration; syntaxonomy; Switzerland; trampling disturbance; Valais; vegetation mapping.

Nomenclature: The nomenclature for vascular plants follows Juillerat et al. (2017).

Abbreviations: $\mathrm{ANOVA}=$ analysis of variance; $\mathrm{DCA}=$ Detrended Correspondence Analysis.

Submitted: 22 August 2019; first decision: 22 August 2019; accepted: 3 September 2019

Scientific Editor: Riccardo Guarino

Linguistic Editor: Lorna Marcham

\section{Introduction}

Alpine vegetation and its harsh site conditions have been important research topics since the beginnings of phytosociological investigations in the early 20th century (BraunBlanquet 1920; Braun-Blanquet et al. 1954). Phytosociological methods have continued to develop ever since (Dierschke 1994; Glavac 1996; Bruelheide 2000; Dengler et al. 2008). The collection of data and the application of findings from vegetation maps are intended to help steer the cultural and agricultural development as well as the intensity of use of an area (Klötzli 2001). The topicality of alpine ecosystems as objects of investigation, also with regard to climatic fluctuations, is thus unbroken. Phytosociological studies can provide information on the stability and carrying capacity of plant communities. From this, the resilience of areas in terms of (recreational) use can be derived (Klötzli 2001).

Tourism and recreational activities often exert pressure on sensitive landscapes and biocoenoses (Eagles et al. 2002). The type and frequency of use determine the strength of the negative impact on plant diversity and vegetation cover (Pickering \& Hill 2007; Mason et al. 2015). In areas with intensive recreational use, damage to habitats and plants can be reduced with planning instruments and regionally adapted visitor management (Rupf 2015). However, coordinated planning and control of recreational use is still lacking 
in many areas of the densely populated European Alps.

The Gornergrat, a panoramic mountain in the Swiss municipality of Zermatt, is heavily frequented for tourism. The transport frequency through the Gornergrat Railway in 2017 was $1,754,000$ persons (BVZ Holding AG 2017). In the summer half-year (May - October), an average of 63,000 people were transported per month (2012-2017), with peaks of over 100,000 people in one month (July 2017; pers. comm. by Gornergrat-Bahn AG pers. comm. 2018). Hikers who walk from the valley to the Riffel Lake are not included in the statistics. In addition, in the summer months 2016/2017 the railway recorded an average of 438 mountain bike transports per month (Gornergrat-Bahn AG pers. comm. 2018). A visit to the Gornergrat is often accompanied by a hike or bicycle ride to the Riffel Lake near the railway station.

The floristic wealth of the Zermatt region and in particular of the Riffel Lake is well documented (Steiner 2002; Käsermann et al. 2003). The lake, together with the Riffelhorn and the Gornergletscher, is under protection (BLN area no. 1707). The aim of the nature reserve is to preserve "the untouched character of natural and wild habitats" and "the mosaic of natural habitats with their characteristic plants" (BAFU 2017). However, the vegetation of mountain lakes with high human activity levels is severely endangered as shown by a study on Grünsee in the Aletsch region (Corrodi 2011). Human trampling causes a strong change of plant communities and can lead to their degradation (Whinam \& Chilcott 2003). The more frequented a trail is, the wider it becomes (Wimpey \& Marion 2010). This is particularly true in alpine areas, where regeneration takes place much more slowly than in lower altitudes (Reisigl \& Keller 1994; Ellenberg \& Leuschner 2010). Through the use of informal paths (walking off the beaten track), the quality of the landscape also decreases over time (Barros \& Marina Pickering 2017). In the Riffel Lake area, the informal, unapproved network of paths is particularly pronounced (pers. observation).

The project "Gornergrat concept" (Gesamtkonzept Gornergrat) strives for improvement of the existing trail network, which then should no longer tempt the users to leave the trails. It is planned (i) to merge several small hiking trails (informal trails) as well as (ii) to design a new separate mountainbike (MTB) trail. Finally, (iii) closed path sections that are no longer used are to be revegetated by means of grass sods (resulting from trail construction) or sowing, and overused areas are to be protected and upgraded (BikePlan AG 2016, unpublished report "Wege des Freizeitverkehrs am Gornergrat - Koordination Gesamtkonzept - Offerte"). The design of the path network is based on the existing topography of the area and can be carried out with low impact and sustainability (little path maintenance), using knowledge of modern path construction (IMBA 2004). However, the effects of this project on the plant communities in the Riffel Lake area were unclear. The detailed route is still in the planning phase and has not yet been reviewed with regard to the vegetation concerned. In view of the planned renewal of the path network in the Riffel Lake area, vegetation-related knowledge about the spatial extent of the habi- tats and the occurrence of red-listed species was required. This knowledge then should lead to recommendations regarding the course of the path and ecological restoration measures.

The present study examines the following questions in the Riffel Lake area of the "Gornergrat concept":

- Do endangered or protected species and habitats occur within the project perimeter?

- Based on the knowledge gained, can recommendations be derived for the trails and for restoration measures of the "Gornergrat concept"?

\section{Study area}

\section{Geographic location}

The Gornergrat, with the Riffel Lake lies above Zermatt in the canton of Valais in Switzerland (Fig. 1). The perimeter of the "Gornergrat concept" is located above the current timber line at about $2800 \mathrm{~m}$ a.s.l. between the Findel and Gorner glaciers and surrounded by alpine grasslands. It can be reached with the Gornergrat Railway (Rotenboden station).

\section{Climate}

The climatic conditions on the Gornergrat and in particular at the Riffel lake are typical for the mountains. At a large scale, the Matter valley is an inner-alpine dry valley with a continental climate. There are large temperature differences between day and night as well as summer and winter, coupled with low precipitation and low humidity. The data from the Gornergrat Station at $3219 \mathrm{~m}$ a.s.l. demonstrate this (MeteoSwiss 2018): The mean annual temperature is $2.2{ }^{\circ} \mathrm{C}$ and the mean annual precipitation is $603 \mathrm{~mm}$ (Fig. 2). The Gornergrat has a mean global radiation of $197 \mathrm{~W} / \mathrm{m}^{2}$ with 2397 hours of sunshine (in comparison: Bern $131 \mathrm{~W} /$ $\mathrm{m}^{2}$ ). There are 275 days of frost, which shortens the vegetation period to a few months, with frost and snowfall being possible at any time.

\section{Geology and soils}

Around the Riffel Lake, on the slightly metamorphic Variscan basement, the Monte-Rosa granite, there are ophiolites. The collective term includes all rocks of the oceanic crust, which were pushed as magma onto the sea floor by the drifting apart of the continental plates. The resulting transformation rocks also belong to the ophiolites, such as the silicate serpentinite, which metamorphosed due to heated, circulating sea water (Gnägi \& Labhart 2015). In the project perimeters, antigonite serpentinite $[(\mathrm{Mg}, \mathrm{Fe}, \mathrm{Ni})$ ${ }_{6} \mathrm{Si}_{4} \mathrm{O}_{10}(\mathrm{OH})_{8}$ ] is the main component of serpentinite, which thus forms the main source rock for local soil formation. Windows of calcareous Bündnerschiefer and Kalkglimmerschiefer provide a mixture with basic minerals (swisstopo 2018).

Due to the very slow pedogenesis at high elevations, rankers to brown soils form from the predominantly siliceous bedrock, depending on the stage of development. Solifluc- 


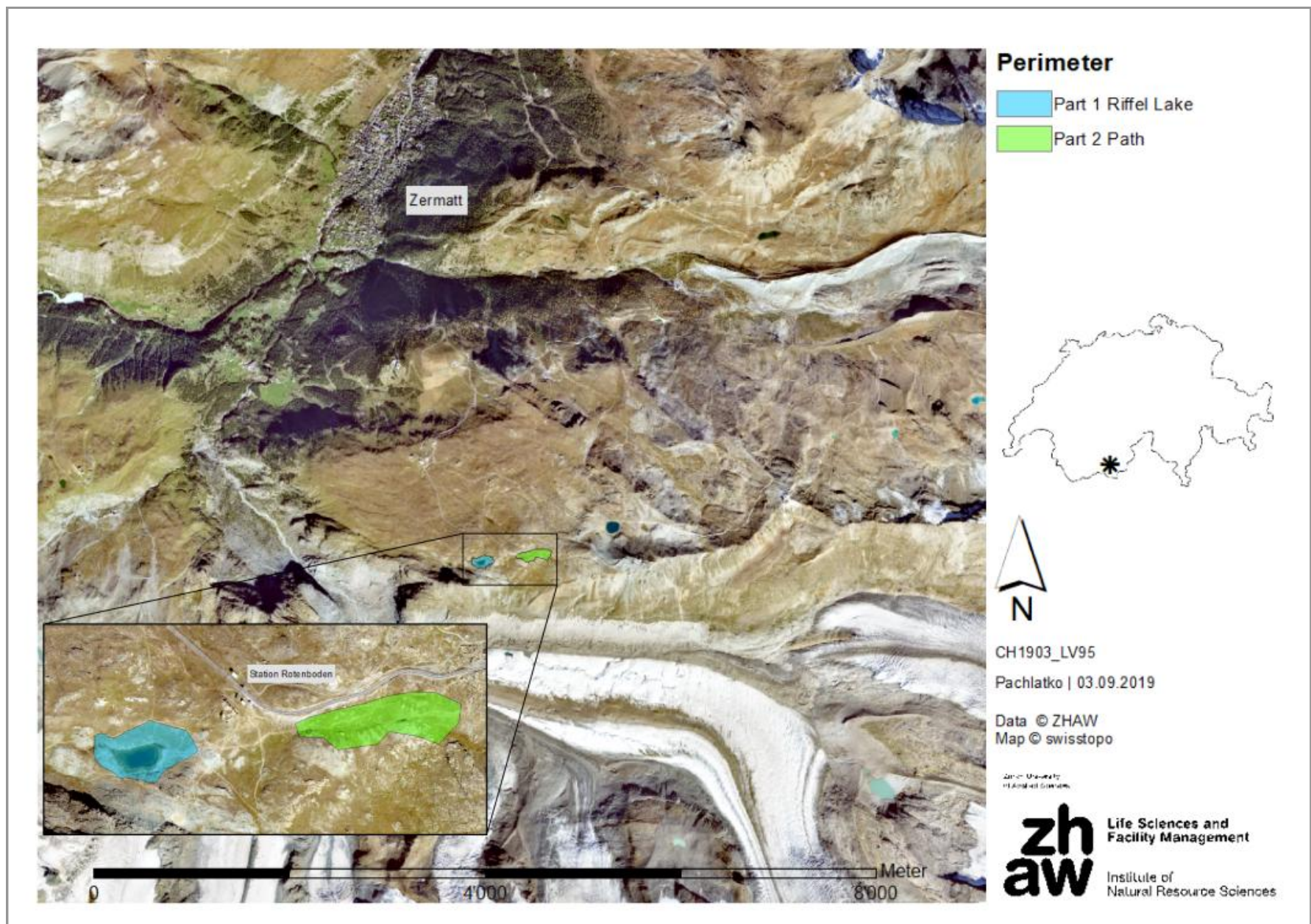

Fig. 1. Location of the study area and perimeter of the "Gornergrat concept" in Zermatt, Switzerland. The project perimeter in blue and green is located between 2600 and 3100 m a.s.l. The Rotenboden station (Coordinates CH1903+ / LV95: 2625328 / 1092580) forms the centre of the perimeter and is closest to the Riffel Lake.

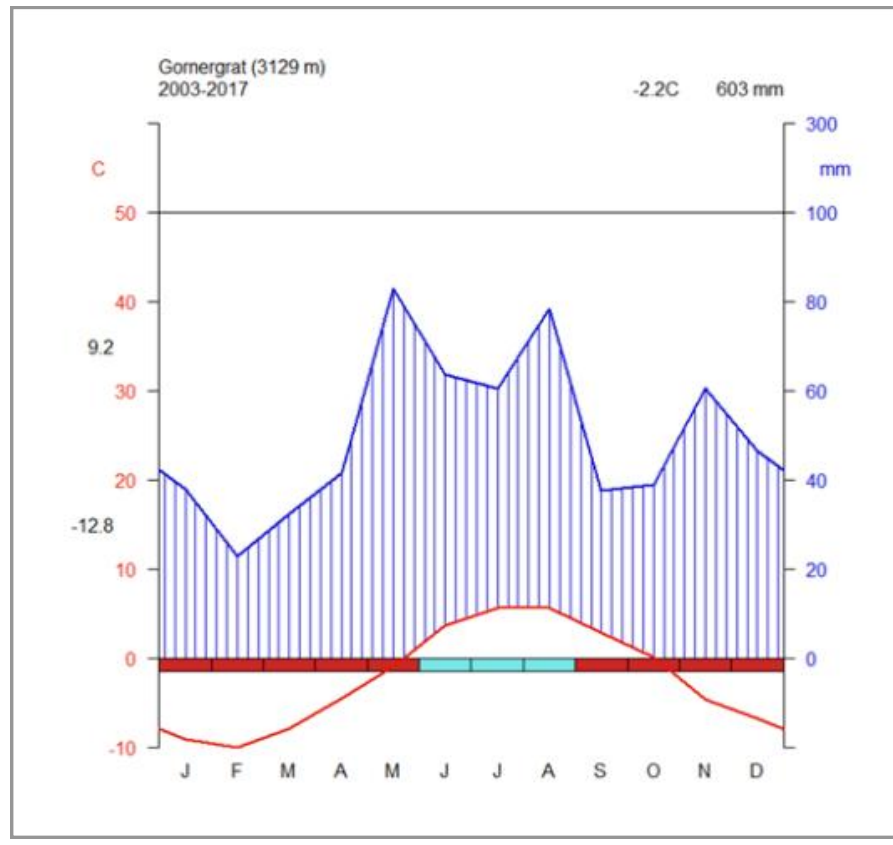

Fig. 2. Climate diagram of the Gornergrat station. Data: MeteoSwiss 2018 (created with R package climatol). tion on slopes with an inclination of more than $2^{\circ}$ and cryoturbation contribute to mixing and loosening of the topsoil as well as to heterogeneous soil characteristics within small areas (Ellenberg \& Leuschner 2010). Based on our own measurements, the mean soil $\mathrm{pH}$ in the project perimeter is 4.5.

\section{Land use}

Since 1942, the summit station has been accessible all year round via the Gornergrat Railway, and has since been used as a skiing area in winter and for hiking in summer. In the course of railway construction and the construction of several mountain hotels, the area was under pressure from construction sites and tourism at an early stage. In recent times, the composition of the vegetation and the soil structure have been changed mainly by ski slope levelling, hiking trail corrections and artificial snow systems.

Marmots (Marmota marmota) are present in large numbers on the south-facing slopes. The entire area is grazed with Valais black head sheep. Of lower importance for vegetation is the influence of even-toed ungulates. The sheep's footfall and grazing characterise the landscape in their own way. Excessive recreational use changes the soil structure more severely in this respect (Fig. 3). Leaking paths prevent a 

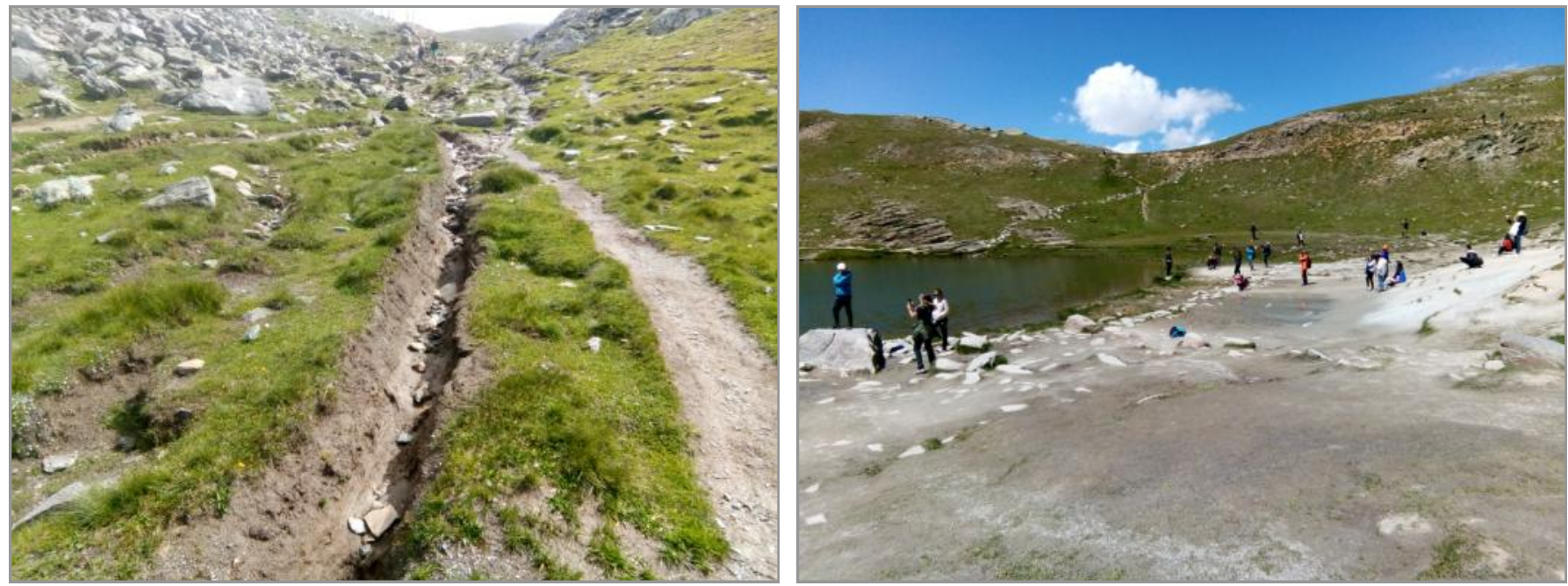

Fig. 3. Left: In steep terrain, deep water grooves form in overused paths and erode the ground. Right: Step loads in the area of the Riffel Lake keep the area vegetation-free. Eroded fine sediments reinforce the effect. Photos: J. Pachlatko, 2018.

closed vegetation cover and cause soil erosion in steep terrain. The sandy to silty components are washed away and displaced by precipitation and melt water. Sometimes deep water grooves or sediment deposits develop, for example in the area of the Riffel Lake. Fine sandy sediments are again compacted by stepping on them, which impedes rapid plant colonisation.

\section{Methods}

\section{Vegetation survey}

The vegetation surveys were conducted in two previously determined investigation perimeters, which are part of the "Gornergrat concept". They were selected because the current trampling impact was particularly high and at the same time new routes for the trails were being planned (Fig. 1). To characterize the vegetation, 32 circular vegetation plots of $10 \mathrm{~m}^{2}$ were recorded in mid-July 2018. The plots were subjectively placed to minimize within-plot heterogeneity and maximize between-plot heterogeneity (Ewald 2003).

In the plots, percentage cover of each vascular plant species was estimated. The field recordings were recorded manually as well as with the software FlorApp for Android (Info Flora 2018) to transmit the recorded data to Info Flora. Species

Table 1. Environmental parameters in the vegetation plots.

\begin{tabular}{lll}
\hline Parameter & Unit & Explanation \\
\hline Coordinates & $\mathrm{m}$ & $\mathrm{CH}$ 1903+ / LV95 \\
\hline Elevation & $\mathrm{m}$ a.s.l. & \\
\hline Slope aspect & ${ }^{\circ}$ & \\
\hline Slope inclination & ${ }^{\circ}$ & \\
\hline Mean soil depth & $\mathrm{cm}$ & $\begin{array}{l}\text { Dengler et al. } \\
(2016)\end{array}$ \\
\hline Maximum microrelief & $\mathrm{cm}$ & $\begin{array}{l}\text { Dengler et al. } \\
(2016)\end{array}$ \\
\hline Vegetation-free surface & $\%$ & $\begin{array}{l}100-\text { total vegeta- } \\
\text { tion cover }\end{array}$ \\
\hline
\end{tabular}

were determined both generatively (Eggenberg et al. 2018; Lauber et al. 2018) and vegetatively (Eggenberg \& Möhl 2013). Plant nomenclature follows Juillerat et al. (2017). We also determined a set of important environmental parameters per plot (Table 1). The plot data were managed with the Swiss program VEGEDAZ (WSL 2017) and are now stored in and are available from the emerging Swiss national vegetation database ("Veg.CH"; J. Dengler et al. in prep.).

\section{Mapping of red list species}

Threatened (Bornand et al. 2016) as well as legally protected species (Art. 20 para. 1 Annex 2, NHV 2017) were searched for and mapped within the entire project perimeter and in particular in the two subperimeters. For this purpose, these areas were walked linearly, and the coordinates of the occurrences of target species were recorded with +/$5 \mathrm{~m}$ accuracy. The inspections took place on four days $(9$, 10,18 and 19 August 2018) in good weather.

\section{Ordination}

The vegetation data were subjected to a Detrended Correspondence Analysis (DCA) with the software "Canoco 5" (version 5.1). Rare species were weighted less (down weighting of rare species). Eight environmental factors were then passively projected into the ordination diagram.

\section{Vegetation classification}

The vegetation was classified with the software Juice (Tichý et al. 2018) using modified TWINSPAN Classification (Hill 1979; Roleček et al. 2009; pseudospecies cut level: 1, minimum group size: 3 , average Sørensen dissimilarity). Clusters with fewer relevés than three were merged at the nexthigher level of the dendrogram. For the final clusters, we determined diagnostic species based on standardised phivalues (Chytrý et al. 2002; Tichy \& Chytrý 2006). Species with phi $\geq 0.5$ were regarded as highly diagnostic, those with phi $\geq 0.25$ as diagnostic for a vegetation unit (Chytrý 2007). The resulting clusters were then interpreted syntax- 

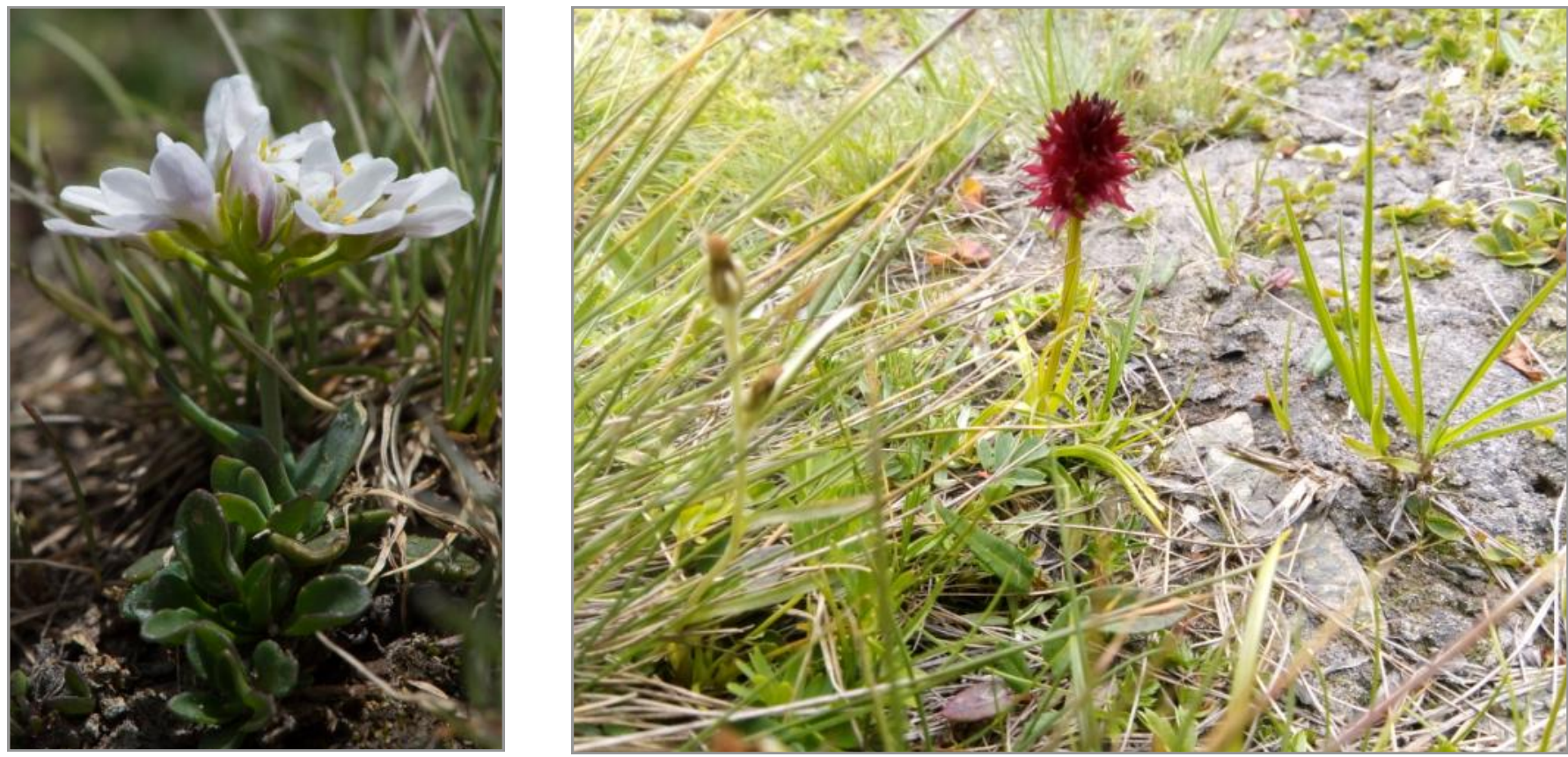

Fig. 4. Left: Thlaspi sylvium (Matterhorn pennycress). Photo: J. Dengler 2018; right: Nigritella rhellicani (Alpine vanilla orchid). Photo: J. Pachlatko 2018.

onomically through comparison with the diagnostic species lists and descriptions in Grabherr \& Mucina (1993); Theurillat et al. (1995), Landolt et al. (2010), Schubert et al. (2010), Pignatti \& Pignatti (2014) and Delarze et al. (2015).

\section{Characterisation and comparison of vegetation units}

The distinguished vegetation units were characterised with mean topographic parameters, mean species richness and mean indicator values according to Landolt et al. (2010). We used analysis of variance (ANOVA) to test for differences in means of these parameters between the distinguished vegetation types, followed by Tukey's post-hoc test (at $\alpha=$ 0.05 ) implemented in R. Based on a visual inspection of the residuals we concluded that deviations from the requirements of linear models were small enough to allow the application of ANOVAs.

\section{Vegetation mapping}

A mapping key derived from the diagnostic species determined in the vegetation classification served as the tool for vegetation mapping. On 6 September 2018, vegetation units were delimited in the field and transferred into digital maps using ArcMap Version 10.5 (ESRI) and overlaid with the information from the route planning.

\section{Results}

\section{Flora}

A total of 109 vascular plant species were found in 32 vegetation plots. In the project perimeter, Thlaspi sylvium (Matterhorn pennycress) was found, which is listed as Vulnerable in the Red List 2016 (Bornand et al. 2016). Also found around the Riffel Lake were some individuals of $\mathrm{Ni}$ - gritella rhellicani, an orchid species which is not endangered but protected according to Art. 20 para. 1 Appendix 2 (NHV 2017) (Fig. 4). A list of the coordinates (CH1903+ / LV95) of the Red List species mapped in the project perimeter is available in Pachlatko (2018).

\section{Ordination}

Axes 1 and 2 in Figure 5 explain most of the variation in species composition with $15.88 \%$ and $6.52 \%$ respectively (eigenvalues: 0.79 and 0.32 ). The gradient length for the first axis is 7.21 SD, which indicates an almost double species change along the gradient (prerequisite for TWINSPAN given). The underlying gradient thus shows a high ecological significance. It is positively related to moisture and negatively to soil reaction and slope aspect. The second axis has a length of 3.45 SD (there are almost no common species at the top and bottom). Here, the underlying gradient can also be assumed to be important for the species occurrence, but there was no strong correlation with any of the seven displayed environmental factors.

\section{Vegetation classification}

Figure 6 shows the dendrogram with six groups from the TWINSPAN classification (maximum Sorensen dissimilarity: 0.576 ). Cluster 4 consisted of only one relevé and was thus merged with cluster 5 .

The result of the summarized TWINSPAN calculation led to the synoptic table (Table 2). The complete vegetation table shows that the five resulting vegetation units are floristically well characterised (for their syntaxonomic interpretation, see Discussion). A selection of their diagnostic species (Table 2) was then used to prepare the mapping key (Pachlatko 2018). 


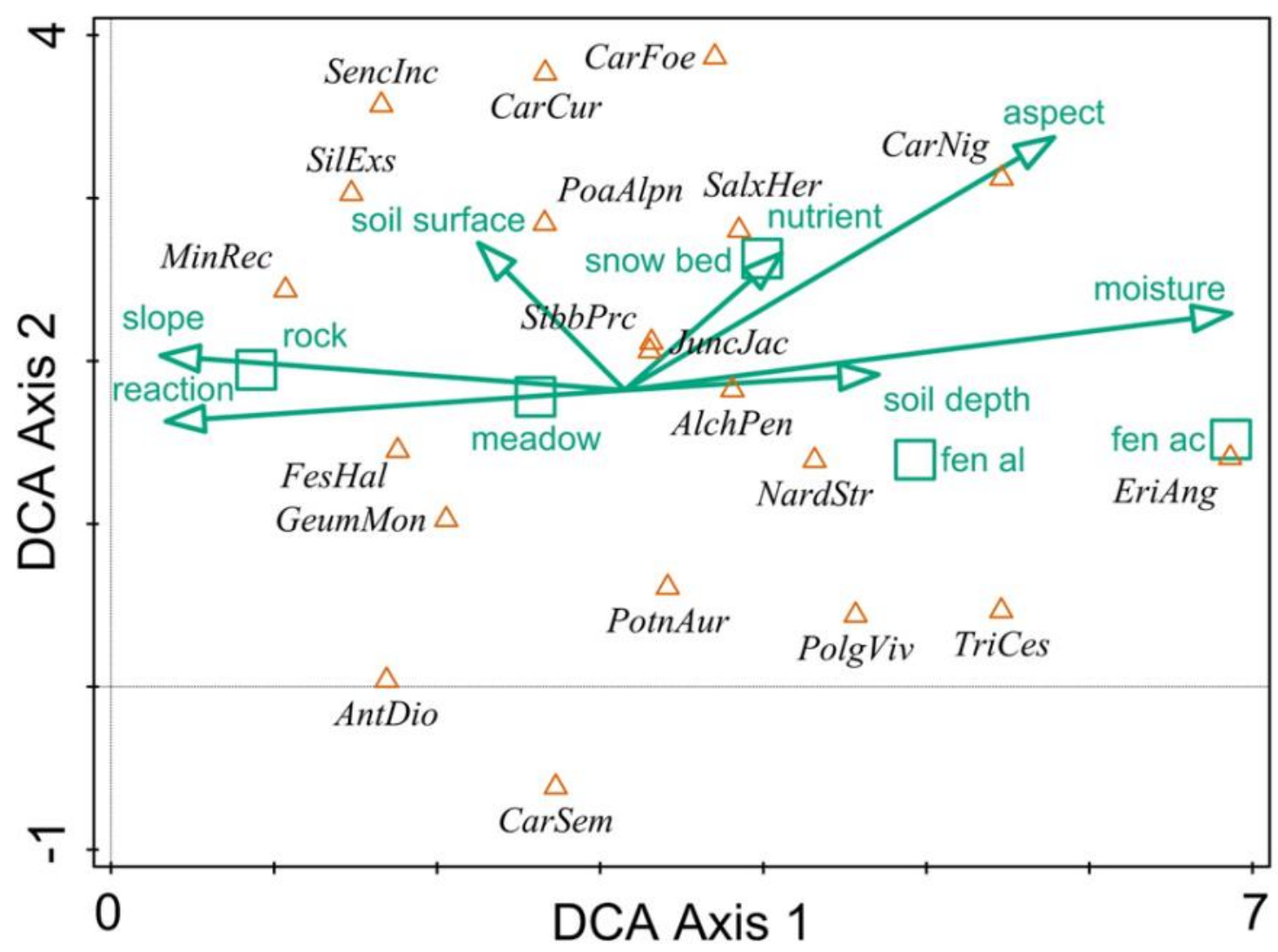

Fig. 5. DCA Ordination of 32 vegetation plots with a total of 109 species. Axis 1 (horizontal) explains $15.9 \%$ of the distribution, axis 2 (vertical) $6.5 \%$. Eigenvalues of the first/second axis: 0.79 and 0.32 ; gradient length: 7.2 and 3.5 SD. The position of the $\mathbf{2 0}$ most common species are shown by triangles (CarSem: Carex sempervirens, AntDio: Antennaria dioica, TriCes: Trichophorum cespitosum, PolgViv: Polygonum viviparum, PotnAur: Potentilla aurea, GeumMon: Geum montanum, NardStr: Nardus stricta, EriAng: Eriophorum angustifolium, AlchPen: Alchemilla pentaphyllea, FesHal: Festuca halleri, SibbPrc: Sibbaldia procumbens, JunJac: Juncus jacquinii, PoaAlpn: Poa alpina, SalxHer: Salix herbacea, MinRec: Minuartia recurva, SilExs: Silene exscapa, CarCur: Carex curvula, CarNig: Carex nigra, Senclnc: Senecio incanus, CarFoe: Carex foetida). The distribution of the five distinguished vegetation types is shown by their centroids (fen ac = fen acidic, fen al = fen alkaline, meadow, rock, snow bed). Finally, the correlation of the mean indicator values (moisture, nutrients, reaction) and of the measured environmental/structural parameters (aspect $=$ slope aspect, slope = slope inclination, soil depth = mean soil depth, soil surface = vegetation-free surface) with the two ordination axes is visualised via arrows.

\section{Comparison of vegetation units}

The five distinguished vegetation units significantly differed in inclination $(p<0.001)$ and vegetation-free surface $(p<$ $0.001)$ and marginally significantly differed $(p=0.054)$ in soil depth (Fig. 7). The vegetation types "meadow" and "rock" inhabited the slopes, while fens and snow beds were found in nearly level areas. However, "meadow" and "rock" strongly differed in open soil, which was high in the rock communities and low (i.e. relatively dense vegetation) in the meadow communities.

Species richness in $10 \mathrm{~m}^{2}$ varied considerably between the vegetation units, being about 10 times higher in the meadow type compared to the acidic fens, with all other units showing intermediate values ( $p<0.001$; Fig. 8). The vegetation units also differed significantly in the means of the ecological indicator values for moisture $(p<0.001)$, nu- trients $(p<0.025)$ and reaction $(p<0.001)$ (Fig. 9). The biggest differences occurred for the moisture values, being high in the two fen types and the snow beds, medium in the meadows and lowest in the rocky communities. The mean nutrient values were generally low, but slightly higher in the snow beds than in the other communities. Reaction values generally indicated acidic conditions, with lowest values in the acidic fens and highest values in the rocky communities, while the three other types were intermediate.

\section{Vegetation mapping}

According to the vegetation mapping (Fig. 10), meadow ("Caricion curvulae") and rocky communities ("Caricion curvulae, rocky") cover most of the area, while the two fen types and snow beds occur only locally in flat areas, mainly around the Riffel Lake. 
Table 2. Complete vegetation table ordered by TWINSPAN clusters with informal names (columns). To the left, the individual relevés are shown, to the right the \% constancies for the five distinguished vegetation units. Diagnostic species are ordered by decreasing phi-values within the clusters. The superscript symbols represent the phi-values $(* *$ phi $\geq 0.50, *$ phi $\geq 0.25,^{\circ}$ phi $>0.00$ ), but without checking for significant concentration. Diagnostic species and joint diagnostic species of vegetation units are marked with frames.

\begin{tabular}{|c|c|c|c|c|c|c|c|c|c|c|c|c|c|c|c|c|c|c|c|c|c|c|c|c|c|c|c|c|c|c|c|c|c|c|c|c|c|}
\hline Vegetation ID & $\%$ & & A & & & & B & & & & & C & & & & & $D$ & & & & & & & & & $\mathrm{E}$ & & & & & & & A & B & $\mathrm{C}$ & $\mathrm{D}$ & $\mathrm{E}$ \\
\hline Plot ID & & 9 & 19 & 20 & & 10 & 112 & 28 & 32 & 4 & 21 & 22 & 23 & 29 & 2 & 5 & 25 & 27 & 31 & 1 & 3 & 6 & 7 & 8 & 121 & 131 & 141 & $15 \quad 16$ & $6 \quad 17$ & 18 & 263 & 30 & $n=4$ & $n=4$ & $n=5$ & $n=5$ & $n=14$ \\
\hline Vegetation type & & & fen ac & cidic & & & now $t$ & bed & & & fen & alkal & & & & & rock & & & & & & & & & neadc & dow & & & & & & $\%$ & $\%$ & $\%$ & $\%$ & $\%$ \\
\hline Diagnostic species fen ac & & & & & & & & & & & & & & & & & & & & & & & & & & & & & & & & & & & & & \\
\hline Eriophorum angustifolium & 28 & 50 & 35 & 50 & & & & 0.1 & & & 12 & 2 & 8 & 42 & & . & . & . & . & . & . & . & . & . & 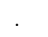 & . & . . & . & . & . & . & . & $100 * *$ & 25 & $80 *$ & & 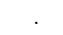 \\
\hline Eriophorum scheuchzeri & 3 & & 25 & . & & & . & . & . & . & . & . & . & . & . & . & . & . & . & . & . & . & . & . & 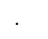 & . & . . & . & . & . & . & . & $25 *$ & . & . & . & . \\
\hline Diagnostic species snow bed & 0 & & & & & & & & & & & & & & & & & & & & & & & & & & & & & & & & & & & & \\
\hline Carex foetida & 19 & & . & . & & 100 & & . & & . & . & . & . & . & . & . & . & . & . & . & . & . & . & .0 & 0.5 & . &. & . 2 & . & 3 & . & . & . & $75 * *$ & . & . & 21 \\
\hline Taraxacum alpinum aggr. & 34 & & . & . & . & 1 & 150 & 0.1 & & . & & 0.1 & 0.1 & & & . & . & . & . & . & . & . & . & 0.51 & 1.5 & . 0 & 0.10. & 0.1 & . & . & 0 & 0.1 & . & $100 * *$ & $40^{\circ}$ & . & $36^{\circ}$ \\
\hline Alchemilla pentaphyllea & 41 & 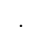 & . & . & . & 20 & 20 & 2 & & 1 & 0.5 & 1 & 0.1 & & & . & . & . & . & . & . & . & . & . & 603 & 35 & . 2 & 250.3 & 3. & . &. & 15 & . & $100 * *$ & $80^{*}$ & . & 36 \\
\hline Salix herbacea & 50 & & . & . & & 50 & 0.1 & 10 & 0.5 & & 0.3 & 1 & 0.5 & & & 0.5 & . & 0.1 & . & . & . & . & . & . & 53 & 352 & 203 & 35 & . & . & 22 & 20 & . & $100^{*}$ & $80^{*}$ & 40 & 43 \\
\hline Eleocharis quinqueflora & 3 & . & . & . & . & & . & . & 20 & . & . & . & . & . & . & . & . & . & . & . & . & . & . & . & . & . & . . & . & . & . & . & . & . & $25^{*}$ & . & . & . \\
\hline Cerastium cerastoides & 6 & . & . & . & . & & 0.1 & . & & . & . & . & . & . & . & . & . & . & $\cdot$ & . & . & . & . & . c & 0.2 & . & . . &.$\quad$. & . & . & . & . & . & $25^{*}$ & . & . & $7^{\circ}$ \\
\hline Phleum alpinum aggr. & 19 & & . & . & . & & .0 & 0.1 & & . & . & . & 0.2 & 0.1 & . & . & . & . & . & . & . & . & . & 0.3 & . & . & . . & . & . & 3 & . & . & . & $50^{*}$ & $40^{\circ}$ & . & 14 \\
\hline Sibbaldia procumbens & 50 & & . & . & . & & 1 & 2 & & . & . & 0.1 & 0.3 & & . & 0.2 & . & . & . & . & . & 5 & . & 0.1 & 71 & 15 & . 1 & 101 & 0.1 & 0.1 & 0.1 & 2 & . & $75^{*}$ & 40 & 20 & $71^{*}$ \\
\hline Cerastium alpinum & 9 & 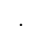 & . & . & . & . & . & . & 0 & . & . & . & . & . & . & . & . & . & . & 0.2 & . & . & . & . & . & . &. & . . & 0.1 & 1. & . & . & . & $25^{*}$ & . & . & $14^{\circ}$ \\
\hline Carex lachenalii & 9 & . & . & . & . & . & . & . & 3 & . & . & . & . & . & . & . & . & . & . & . & . & . & . & . & . & . 0 & 0.10. & 0.1 . & . & . & . & . & . & $25^{*}$ & . & . & $14^{\circ}$ \\
\hline Gnaphalium supinum & 28 & . & . & . & . & 10 & 0.2 & . & . & 0 & 0.1 & . & . & . & . & . & . & . & . & . & . & . & . & .0 & 0.30 & 0.2 & . 0. & 0.20 .1 & 1 . & . & .0 & 0.1 & . & $50^{*}$ & $40^{\circ}$ & . & $36^{\circ}$ \\
\hline Deschampsia cespitosa & 6 & & . & . & & & . & . & 2 & & 0.1 & & . & . & 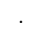 & . & . & . & . & . & . & . & . & . & . & . & . . & . & . & . & . & . & . & $25^{*}$ & $20^{\circ}$ & . & . \\
\hline Diagnostic species fen al & & & & & & & & & & & & & & & & & & & & & & & & & & & & & & & & & & & & & \\
\hline Trichophorum cespitosum & 16 & & . & . & . & & . & . &. & 6 & 8 & 3 & 12 & & & . & . & . & . & . & . & . & . & . & . & . &. & . & . & . & . & . & . & . & $100^{* *}$ & . & . \\
\hline Primula farinosa & 16 & . & . & . & . & & .0 & 0.1 &. & 5 & 0.2 & 0.2 & 0.1 & & & . & . & . & . & . & . & . & . & . & . & . &. & . & . & . & . & . & . & $25^{\circ}$ & $80^{* *}$ & . & . \\
\hline Carex nigra & 25 & & . & . & 2 & & . & 65 & 20 & 0.1 & 35 & 30 & 32 & 15 & & . & . & . & . & . & . & . & . & . & . & . & . . & . & . & . & . & . & 25 & $50^{\circ}$ & $100 * *$ & & . \\
\hline Pinguicula spec. & 6 & . & . & . & . & . & . & . & . & & 0.1 & 0.2 & . & & & . & . & . & . & . & . & . & . & . & . & . &. & . & . & . & . & . & . & . & $40^{* *}$ & . & . \\
\hline Viola biflora & 6 & . & . & . & . & . & . & . & . & . & . & 0.3 & 0.1 & & & . & . & . & . & . & . & . & . & . & $\cdot$ & $\cdot$ & .. & .. & . & . & . & . & . & . & $40^{* *}$ & . & . \\
\hline Loiseleuria procumbens & 9 & r. & . & . & . & . & . & . & . & . & 1 & . & 0.3 & & & . & . & . & . & . & 15 & . & . & . & . & . & . . & . . & . & . & . & . & . & . & $40^{* *}$ & . & 7 \\
\hline Homogyne alpina & 9 & . & . & . & . & & . & . &. & 3 & 1 & . & . & & & . & . & . & . & . & 0 & . & . & . & . & . &. & . . & . & . & . & . & . &. & $40^{* *}$ & . & 7 \\
\hline Polygonum viviparum & 47 & . & . & . & $\cdot$ & & 0.1 & 2 & 0.1 & 7 & 3 & . & 0.1 & 0 & & 0.1 & . & 1 & . & 0.5 & & 5 & $\cdot$ & 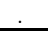 & & 0.1 & 0. & 0.30 .5 & 5 & 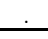 & & 0.2 & . & $75 *$ & $80^{*}$ & 40 & 43 \\
\hline Leontodon helveticus & 41 & & . & . & . & & . & . & 0.2 & 2 & & 0.1 & 0.1 & & & 0 & 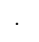 & . &. & 0.1 & 0.2 & 0.1 & 0.1 & c & 0.10 & 0.2 & & 0.3 & . & & 0.1 & & . & 25 & $60^{*}$ & 20 & $57 *$ \\
\hline $\begin{array}{l}\text { Joint diagnostic species rock } \\
\text { and meadow }\end{array}$ & & & & & & & & & & & & & & & & & & & & & & & & & & & & & & & & & & & & & \\
\hline Minuartia recurva & 59 & & . & . & . & & 0.1 & . & . & . & 0 & . & . & & 4 & 1.5 & 5 & 4 & 0.3 & 32 & . & 0.5 & 51 & 0.50 & 0.50 & 0.3 & 10. & 0.22 & 2 & 1 & 1 & & . & 25 & 20 & $100 * *$ & $86^{*}$ \\
\hline Ligusticum mutellinoides & 59 & & . & . & . & 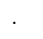 & . & . & . & . & 0.1 & 0.1 & 0.1 & & . & 0.5 & 0.1 & 0.1 & 0.1 & 0.2 & 0 & 0.1 & 10 & .0 & 0.10 & 0.10 & 0.20. & 0.30 .1 & 10.2 & 2 & & 0.2 & . & . & $60^{\circ}$ & $80^{*}$ & $86^{*}$ \\
\hline Festuca halleri aggr. & 53 & & . & . & . & . & . & . & . & . & . & . & . & & 8 & 15 & 1 & . & . & 30 & 10 & 30 & 25 & 25 & 1 & 10 & 0.35 & 57 & 15 & 30 & 3 & 15 & . & . & . & $60^{*}$ & $100^{* *}$ \\
\hline Sempervivum arachnoideum & 28 & & . & . & . & . & . & . & . & . & . & . & . & & 5 & 0 & . & . & 2 & 0.1 & . & . & 0.1 & 0.5 & . & . &. & 0.1 & 18 & . & 0.1 & . & . & . & . & $60^{*}$ & $43^{*}$ \\
\hline Draba aizoides & 28 & & . & . & . & & . & . & . & . & . & . & . & & 0 & 0 & 0.1 & . & . & 0 & . & r. & . & 0.1 & . & . 0 & & 0.1 & 0.1 & 1 . & & 0.1 & . & . & & $60^{*}$ & $43^{*}$ \\
\hline Sempervivum montanum & 28 & & . & . & . & . & . & . & . & . & . & . & . & & 0.5 & 50 & 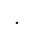 & 0.2 & . & 0.2 & 0.1 & . & 2 & 0.5 & . & . & . . & . & 3 & 1 & & & . & . & & $60^{*}$ & $43^{*}$ \\
\hline Hieracium piliferum aggr. & 25 & & . & . & . & 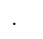 & . & . & . & . & . & . & . & & & 0.1 & . & 0.5 & . & . & 0.2 & . & 0.5 & . & 00 & 0.10 & 0.1 . & . & . & . & 0.1 & . & . & . & & $40^{*}$ & $43^{*}$ \\
\hline Cardamine resedifolia & 28 & & . & . & . & . & . & . & . & . & . & . & . & & 0 & & 0.1 & & & . & 0 & & 0.1 & & & 0.1 & & 0.1 & 10.1 & 10.1 & & 0.1 & . & . & 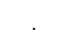 & $40^{*}$ & $50 *$ \\
\hline Diagnostic species rock & & & & & & & & & & & & & & & & & & & & & & & & & & & & & & & & & & & & & \\
\hline Thlaspi sylvium & 22 & . & . & . & . & . & . & . & . & . & . & . & . & . & 0.1 & 0.1 & 0.1 & 0 & . & 0 & . & . & . & 0.5 & . & . & . . & . 0 & . & . & . & . & . & . & . & $80^{* *}$ & $21^{\circ}$ \\
\hline $\begin{array}{l}\text { Thymus praecox subsp. } \\
\text { polytrichus }\end{array}$ & 22 & & . & . & . & . & . & . & . & . & . & . & . & & 2 & 0.5 & 3 & . & 1 & 0.5 & 5 & . & . & 0.5 & . & . & . . & . & . & . & 0.3 & . & . & . & . & $80^{* *}$ & $21^{\circ}$ \\
\hline Festuca intercedens & 13 & $\cdot$ & . & . & . & . & . & . & . & . & . & . & . & & r. & . & 4 & 4 & 3 & 0.1 & . & . & . & . & . & . & .. & . & . & . & . & . & . & . & . & $60^{* *}$ & 7 \\
\hline Phyteuma hemisphaericum & 6 & & . & . & . & . & . & . & . & . & . & . & . & & 0.1 & 1. & . & . & 0.5 & $\cdot$ & . & . & . & . & . & . & .. & . & . & . & . & . & . & . & & $40^{* *}$ & $\cdot$ \\
\hline Salix retusa & 6 & & . & . & . & . & . & . & . & . & . & . & . & & . & . & . & 15 & 5 & . & . & . & . & . & . & $\cdot$ & .. & . & . & . & . & . & . & . & . & $40^{* *}$ & . \\
\hline Campanula scheuchzeri & 31 & & . & . & . & . & . & . & . & 0 & 0 & . & . & . & 0 & 0.1 & . & 0.1 & & 0 & . & . & . & 0 & . & . &.$\quad$. & . & . & . & & 0.1 & . & . & $40^{\circ}$ & $80^{* *}$ & 29 \\
\hline Phyteuma globulariifolium & 9 & & . & . & . & 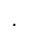 & . & . & . & . & . & . & . & & & . & 0.2 & 0.1 & $\cdot$ & . & . & . & . & . & . & . & . . & . & . & . & 0 & . & . & . & . & $40^{*}$ & 7 \\
\hline Erigeron uniflorus & 13 & & . & . & . & & . & . & . & . & . & . & . & & 0.1 & 1. & . & 0.1 &. & & . & . & . & 0.1 & . & . & . . & . & 0.2 & 2 & . & . & . & . & & $40 *$ & $14^{\circ}$ \\
\hline Diagnostic species meadow & & & & & & & & & & & & & & & & & & & & & & & & & & & & & & & & & & & & & \\
\hline Leucanthemopsis minima & 41 & & . & . & $\cdot$ & & 0.5 & . & . & . & . & . & . & & r. & . & . & . & $\cdot$ & 0.2 & 0 & 0.1 & 1 & $0.3 c$ & 0.30 & 0.10 & 0.1 . & .0 .3 & 30.2 & 21 & & & . & $25^{\circ}$ & . & . & $86^{* *}$ \\
\hline $\begin{array}{l}\text { Senecio ir } \\
\text { incanus }\end{array}$ & 44 & & . & . & $\cdot$ & . & . & . & . & . & . & . & . & - & 0 & 0.1 & . & . & $\cdot$ & . & . & 1 & 0.1 & 10 & 0.10 & 0.10 & 0.10. & 0.10 .3 & 34 & 1 & 20 & 0.5 & . & . & . & $40^{\circ}$ & $86^{* *}$ \\
\hline Luzula spicata & 34 & & . & . & . & . & . & . & . & . & . & . & . & . & 0.2 & 2 & . & . & . & 0.5 & . & 1 & 0.5 & 0.50 & 0.20 & 0.1 & . 0. & 0.11 & . & 0.3 & . 0 & 0.4 & . & . & . & 20 & $71^{* *}$ \\
\hline Geum & 34 & & . & . & . & 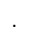 & . & . & . & 2 & . & . & . & . & . & . & . & . &. & 17 & 1 & 7 & 5 & 5 & . & . & . 1 & 11 & 7 & 5 & . & 4 & . & . & $20^{\circ}$ & . & $71^{* *}$ \\
\hline Gentiana brachyphylla & 38 & & . & . & . & . & . & . & . & 0.1 & . & . & . & . & 0 & . & . & . &. & 0.1 & 0 & 0.3 & 0.1 & 0.10 & 0.1 & . & . 0. & 0.1 . & 0.2 & 20.3 & .0 & 0.3 & . & . & 20 & 20 & $71^{* *}$ \\
\hline Lotus alpinus & 16 & & . & . & . & . & . & . & · & . & . & . & . & . & $\cdot$ & . & . & . & $\cdot$ & 2 & . & 1 & 0.1 & $0.5 \mathrm{C}$ & 0.1 & . &. &.$\quad$. & . & . & . & . & . & . & . & . & $36^{* *}$ \\
\hline Carex curvula & 28 & & . & . & . & & . & . & 15 & . & . & . & . & . & . & . & . & . & . & . & . & 3 & 2 & 0.5 & . & . & . 1 & 115 & 510 & 25 & . & 3 & . & $25^{\circ}$ & . & . & $57^{* *}$ \\
\hline Silene exscapa & 41 & & . & . & . & 0.1 & . & . & . & . & . & . & . & . & . & 0.4 & . & 5 & $\cdot$ & . & . & 2 & . & $0.5 \mathrm{c}$ & 0.20 & 0.3 & 11 & 10.3 & 38 & 0.1 & . & 2 & . & 25 & . & $40^{\circ}$ & $71^{*}$ \\
\hline Veronica alpina & 13 & & . & . & . & & . & . & . & . & . & . & . & . & . & . & . & . & . & . & . & 0.1 & . & . 0 & 0.10 & 0.1 & .0 & 0 & . & . & 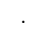 & . & . & . & . & . & $29^{*}$ \\
\hline Myosotis alpestris & 13 & & . & . & . & & . & . & . & . & . & . & . & $\cdot$ & . & . & . & . & $\cdot$ & r. & . & 0.1 & 0.1 & . & . & . &.$\quad$. & . . & 0.1 & 1. & .0 & 0.1 & . & . & . & . & $29 *$ \\
\hline Pedicularis kerneri & 13 & & . & . & . & . & . & . & . & . & . & . & . & . & . & . & . & . & $\cdot$ & $\cdot$ & . & $\cdot$ & . & . & 0 & & 0.1. & .0 .1 & 1 . & . & 0.1 & & . & . & . & . & $29^{*}$ \\
\hline Poa alpina & 41 & & . & . & . & 70 & 0.5 & . & . & . & . & . & . & . & & 0.1 & . & . & & 0.2 & 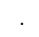 & 1 & 0.1 & 0.30 & 0.5 & . 0 & 0.31 & 11 & . & . & & 0.5 & 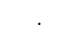 & $50^{\circ}$ & - & 20 & $71^{*}$ \\
\hline
\end{tabular}


Table 2. Continuation.

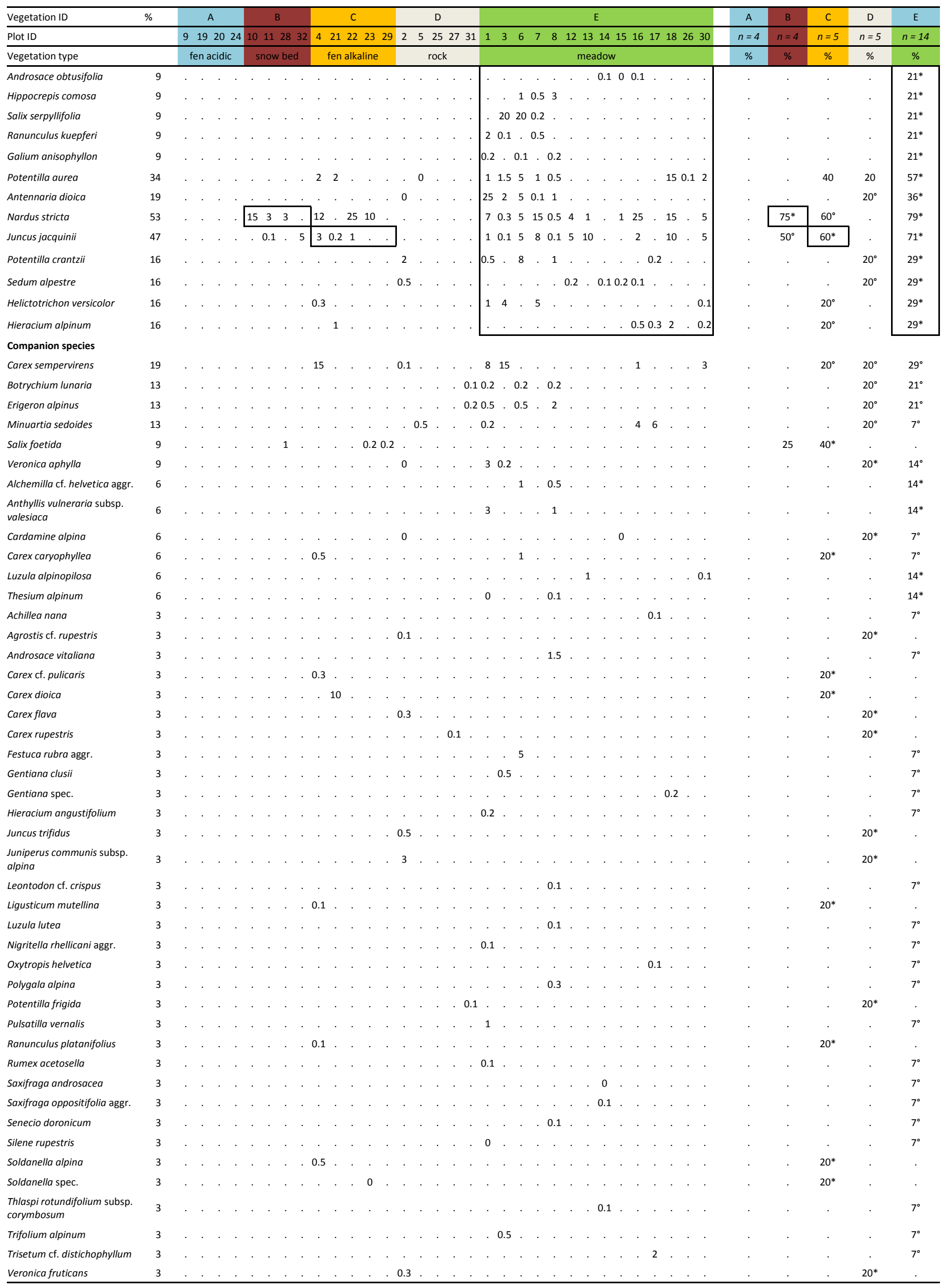




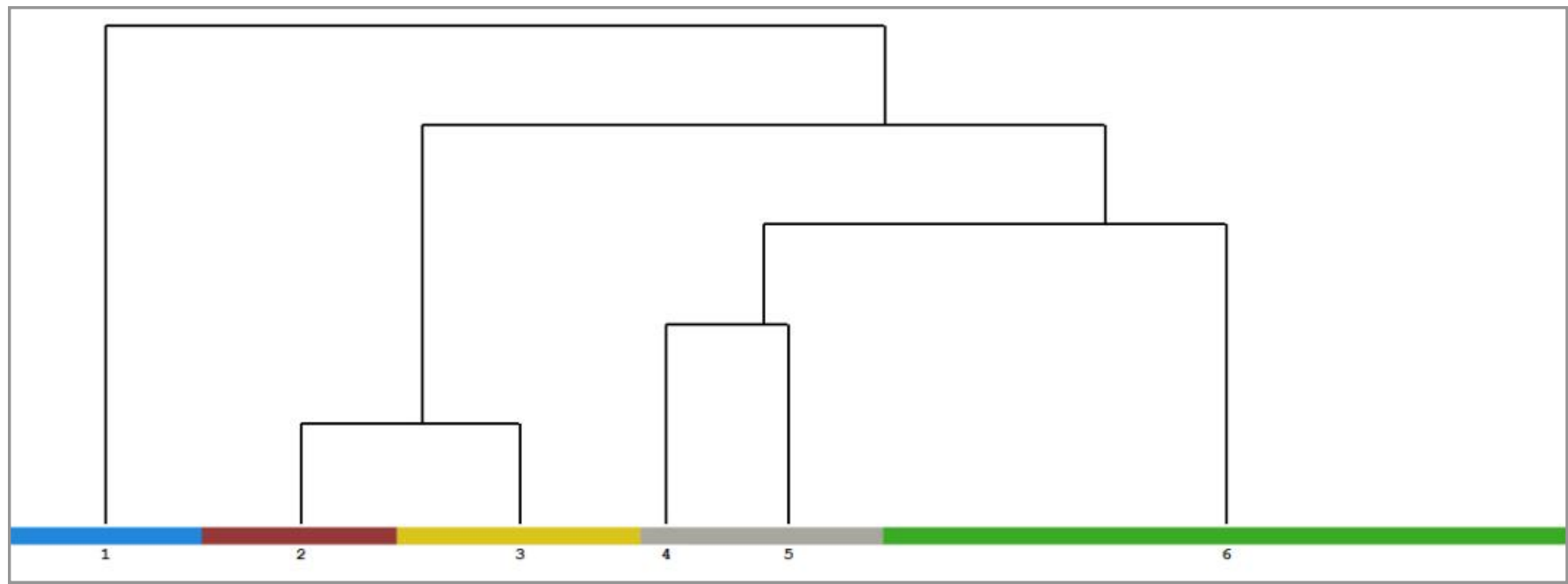

Fig. 6. Dendrogram from Juice with 6 clusters (maximum Sorensen dissimilarity: 0.576 ) Cluster 4 and 5 were merged into one cluster. The informal names used in this work are as follows: 1 - "fen acidic", 2 - "snow bed", 3 - "fen alkaline", 4 and 5 - "rock", 6 - "meadow".
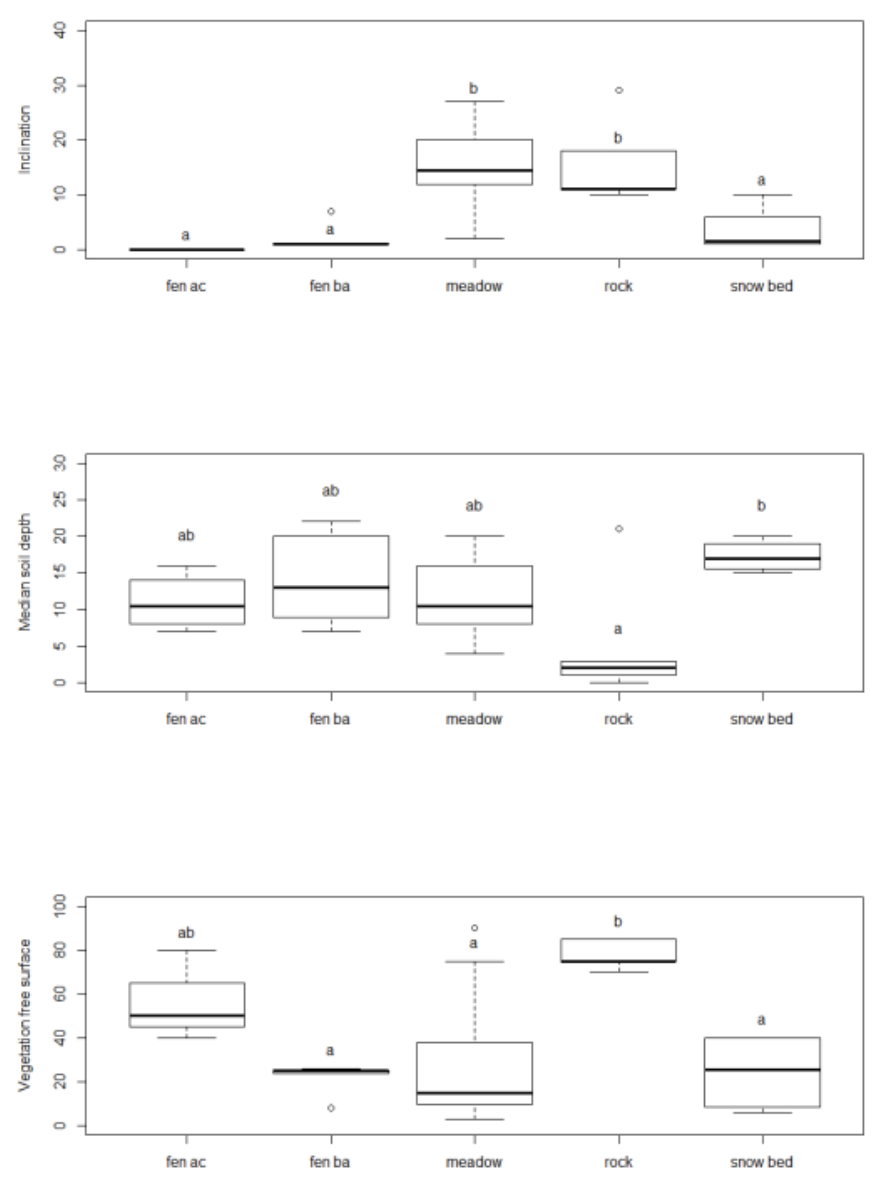

Fig. 7. Boxplots of topographic and soil parameters in comparison between the five distinguished vegetation types (fen acidic, fen alkaline, meadow, rock and snow bed). The superscript letters indicate homogeneous groups according to Tukey's post-hoc test.

\section{Discussion}

\section{Species and their distribution}

The species found are typical and well-known for the siliceous Alps at the given elevation (Info Flora 2018); Thlaspi sylvium (Matterhorn pennycress) was the only Red List species. In all of Switzerland, this species only occurs in a small territory around the study area $\left(<20 \mathrm{~km}^{2}\right)$ and is listed as Vulnerable according to IUCN criterion D2 (Bornand et al. 2016). Accordingly it has a high national priority (BAFU 2011). Due to further distribution areas in the Italian/French Cottian and Grajan Alps (Sauerbier \& Langer 2017), the species is not listed on the international list of endangered species (Bilz 2011). Category D2 stands for a very small distribution area in which a species can disappear in a very short time due to the effects of human activity or accidental events. On the Gornergrat and in the wider surroundings of Zermatt, the plant species must therefore be given increased attention, as these areas are used heavily for recreation and tourism.

The species list of the current study reflects a large part of the local vegetation but cannot be considered complete due to the fact that sampling took place only during part of the season. According to Info Flora (2018) six additional nationally red-listed species occur or occurred in the project perimeter (Table 3).

The orchid Nigritella rhellicani (Alpine vanilla orchid) found in the project perimeter is protected according to the $\mathrm{Na}$ ture and Cultural Heritage Ordinance of Switzerland. However, this species is distributed widely in the entire Swiss Alps and Jura Mts. and not endangered (Info Flora 2018).

The marsh plants Eriophorum scheuchzeri and Carex nigra were found at the Riffel Lake at $2770 \mathrm{~m}$ a.s.l. These occurrences, which are regarded as elevational records 


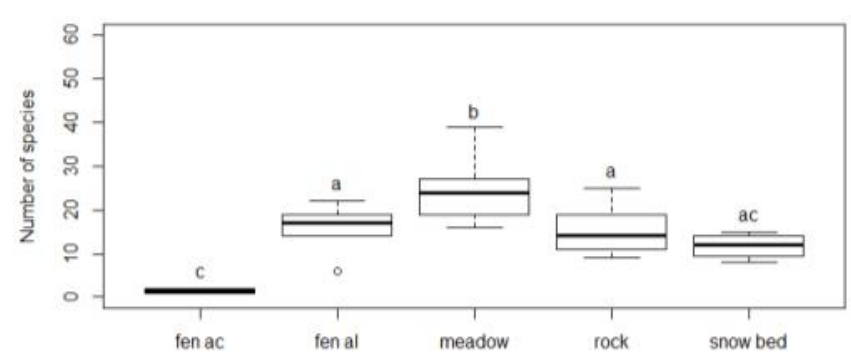

Fig. 8. Boxplots for species richness of vascular plants in $10 \mathrm{~m}^{\mathbf{2}}$ in comparison between the five distinguished vegetation types (fen acidic, fen alkaline, meadow, rock and snow bed). The superscript letters indicate homogeneous groups according to Tukey's post-hoc test.
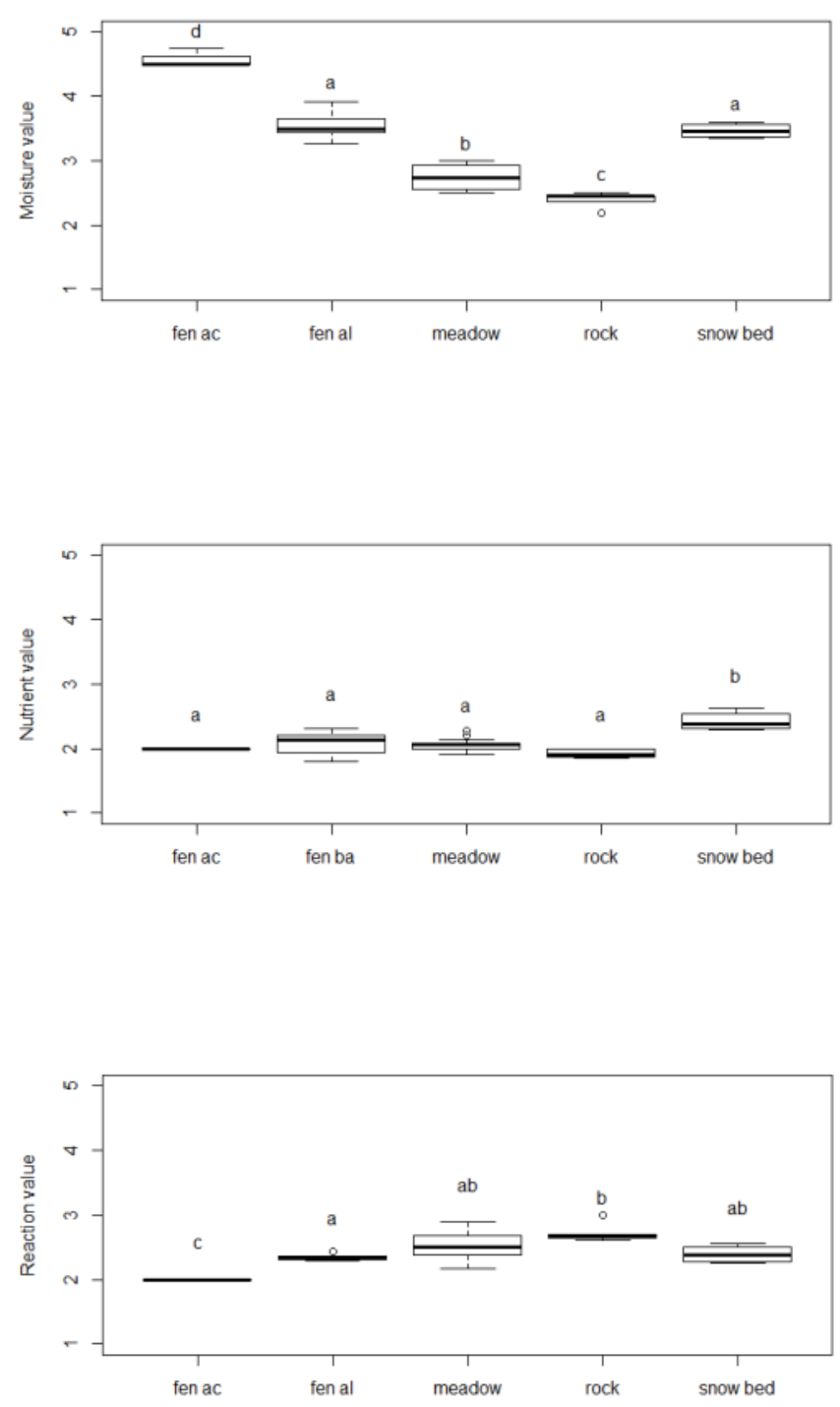

Fig. 9. Boxplots of mean indicator values for soil properties in comparison between the five distinguished vegetation types (fen acidic, fen alkaline, meadow, rock and snow bed). The superscript letters indicate homogeneous groups according to Tukey's post-hoc test.
Table 3. Red List Species of the Info Flora database for the study area Gornergrat (project perimeter). The finds were reported by various persons, including explicit Red List inspections. The endangerment criteria (including subcategories) stand for A: decrease in population size and C: general population size.

\begin{tabular}{ccc}
\hline Red List species & $\begin{array}{c}\text { Red List } \\
\text { category }\end{array}$ & IUCN criteria \\
\hline Artemisia borealis & $\mathrm{VU}$ & $\mathrm{C} 2 \mathrm{a}(\mathrm{i})$ \\
\hline Carex atrofusca & $\mathrm{VU}$ & $\mathrm{C} 2 \mathrm{a}(\mathrm{i})$ \\
\hline Carex maritima & $\mathrm{VU}$ & $\mathrm{A} 2 \mathrm{c}, \mathrm{A} 3 \mathrm{c}$ \\
\hline Phyteuma humile & $\mathrm{VU}$ & $\mathrm{C} 1, \mathrm{C} 2 \mathrm{a}(\mathrm{i})$ \\
\hline Taraxacum pacheri & $\mathrm{VU}$ & $\mathrm{A} 2 \mathrm{c}, \mathrm{C} 1, \mathrm{C} 2 \mathrm{a}(\mathrm{i})$ \\
\hline Trifolium saxatile & $\mathrm{VU}$ & $\mathrm{C} 1, \mathrm{C} 2 \mathrm{a}(\mathrm{i})$ \\
\hline
\end{tabular}

(Käsermann et al. 2003), are due to the protected location of the lake. Here a total of eleven marsh and aquatic plants have their alpine elevation record (among others also Sparganium angustifolium, Ranunculus trichophyllus subsp. eradicatus, Potamogeton berchtoldii, Carex davalliana, Juncus triglumis) (Käsermann et al. 2003).

\section{Ordination}

The length of the first ordination axis shows the high importance of the underlying factors. The distribution of species along this axis (left: Minuartia recurva; right: Eriophorum angustifolium) together with the relative length and the angle of the arrow "weighted moisture number" indicate that this axis mainly reflects a moisture gradient. In the diverse mosaic structure of the investigated landscape, this seems plausible, particularly under the dry climate of the Gornergrat: depressions with higher humidity represent a blatant contrast to the exposed hilltop location (Käsermann et al. 2003). For the second ordination axis, we did not find strong correlation with any of the measured or inferred parameters, so likely a non-measured parameter (or a combination of several parameters) is responsible for the differentiation along this axis.

\section{Syntaxonomic assignment}

The acidophilous snowbeds could readily be assigned to the Salicetum herbaceae (class Salicetea herbaceae), which was already described in the early days of phytosociology by Rübel in 1911 (Grabherr \& Mucina 1993; Pignatti \& Pignatti 2014). The cluster "fen acidic" could equally well be assigned to the alliance Caricion fuscae (order Caricetalia fuscae, class Scheuchzerio palustris-Caricetea fuscae). In the area it is represented by two extremely species-poor communities in the shallow waters of the Riffel lake: the wellknown Eriophoretum scheuchzeri and one-species stands of Eriophorum angustifolium. The cluster "fen alkaline" actually forms a transition between the orders Caricetalia fuscae and Caricetalia davallianae, of acidic and base-rich fens respectively, which also is reflected by the mean reaction values that were only slightly higher than in "fen acidic". Based on the presence of Primula farinosa with a constancy of $80 \%$ and a phi-value of 0.72 , we placed it preliminarily into 

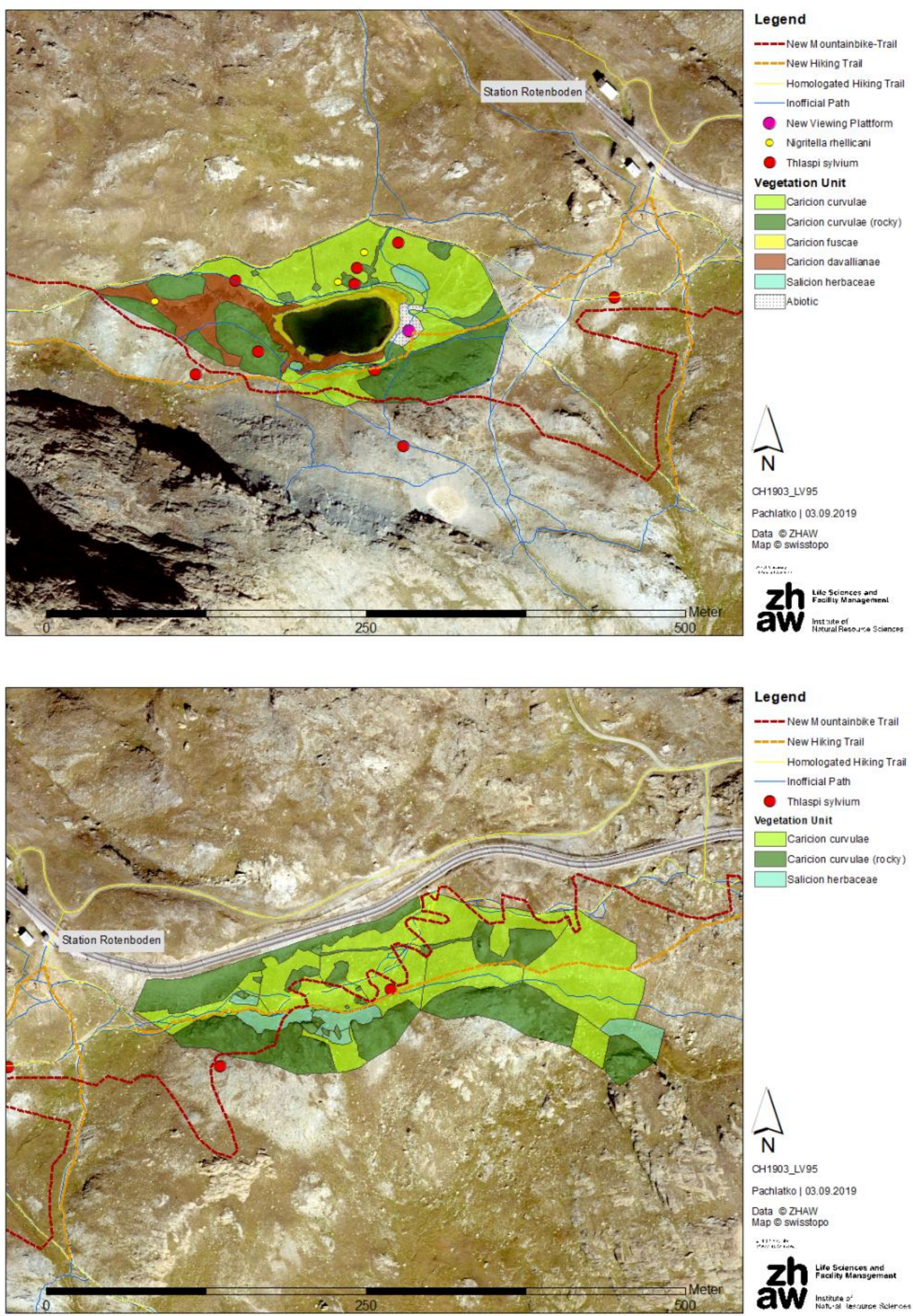

Fig. 10. Detailed vegetation maps of the two parts of the study perimeter. The vegetation units are shown with the names according to the assignment in the Discussion: fen acidic = Caricion fuscae; fen alkalilne = Caricion davallianae; meadow = Caricion curvulae; rock = Caricion cuvulae (rocky); snow bed = Salicion herbaceae. 
the Caricetalia davallianae/Caricion davallianae, where this species is considered a character species (Grabherr \& Mucina 1993; Theurillat et al. 1995; Delarze et al. 2015). The two dominating graminoids, Carex nigra and Trichophorum cespitosum, are generally considered as diagnostic species of the class, thus occurring in both acidic and base-rich fens (Grabherr \& Mucina 1993; Theurillat et al. 1995). Therefore, the rather low mean indicator values for soil reaction in the case of "fen alkaline" might be due to the fact that the indicator values of Landolt et al. (2010: both 2, corresponding to acidic $=\mathrm{pH} 3.5-6.5)$ underestimate the true amplitude of the species.

The two remaining vegetation types, "meadow" and "rock", share many diagnostic species, in particular Minuatria recurva, Ligusticum mutellinoides and Festuca halleri ("Joint diagnostic species" in Table 2), which have their main occurrences in the order Caricetalia curvulae (class: Juncetea trifidi) (Landolt et al. 2010). The "meadows" with their relatively close sward (Fig. 7) and further diagnostic species of the Caricetalia curvulae, e.g. Leucanthemopsis minima, Senecio incanus, Geum montanum and Carex curvula (Table 2), clearly fall into this order. They can be readily identified with the Festucetum halleri, which Grabherr \& Mucina (1993) characterise as a community of the central Alps on warm and dry slopes occurring at 2100-2600 m a.s.l. in Austria. With $2800 \mathrm{~m}$ a.s.l. the occurrences at Gornergrat are even higher up. The syntaxonomic placement of the "rock" unit is a challenge. While it shares numerous species with the "meadow" unit, it has a much more open vegetation structure (approx. $20 \%$ cover vs. $80 \%$ cover; Fig. 7 ). The local diagnostic species Festuca intercedens and Phyteuma hemisphaericum point into the direction of the class Carici rupestris-Kobresietea bellardii, while Thlaspi sylvium and Salix retusa point to the class Thlaspietea rotundifolii. The open, rocky character together with the frequent occurrence of Sempervivum arachnoideum and S. montanum would suggest that the unit could also belong to the alliance SedoScleranthion of the class Sedo-Scleranthetea (Grabherr \& Mucina 1993; Delarze et al. 2015). We could not find any association in the literature that matches our type, which occurs frequently and rather homogeneously throughout the study area. Therefore, we treat it here as informal Sempervivum arachnoideum-Minuartia recurva community, which we place preliminarily in the Caricion curvulae.

Proposed syntaxonomic scheme (higher ranks according to Mucina et al. 2016)

\section{Class Salicetea herbaceae Br.-BI. 1948}

Order Salicetalia herbaceae Br.-BI. in Br.-BI. \& Jenny 1926

Alliance: Salicion herbaceae Br.-BI. in Br.-BI. \& Jenny 1926

"Snow bed": Salicetum herbaceae Rübel 1911 (Fig. 11)

\section{Class Scheuchzerio palustris-Caricetea fuscae Tx. 1937}

Order Caricetalia fuscae Koch 1926

Alliance: Caricion fuscae Koch 1926 nom. conserv. propos.
"Fen acidic": Eriophoretum scheuchzeri (Rübel 1911) Fries 1913 and Eriophorum angustifolium community (Fig. 12)

Order Caricetalia davallianae Br.-BI. 1950 nom. conserv. propos.

Alliance: Caricion davallianae Klika 1934

"Fen alkaline": Primula farinosa-Trichophorum cespitosum community (Fig. 13)

\section{Class Juncetea trifidi Hadač in Klika \& Hadač 1944}

Order Caricetalia curvulae Br.-BI. in Br.-BI. \& Jenny 1926

Alliance: Caricion curvulae Br.-BI. 1925

"Meadow": Festucetum halleri Br.-BI. in Br.-BI. \& Jenny 1926 (Fig. 14)

"Rock": Sempervivum arachnoideum-Minuartia recurva community (Fig. 15)

\section{Vegetation map}

The vegetation map of Steiner (2002) at the alliance level at large scale agrees with our study, but comes to different conclusions at small scales in the area of the Riffel Lake (Fig. 10). Specifically, Steiner classified the shores and fens of subarea 1 (Riffel Lake) differently and did not distinguish snow bed communities at all. With regard to the riparian vegetation, Steiner describes the situation as alluvial bank (TypoCH: 2.2.5), while we divided them into two alliances. On the one hand the non-calcareous fen (Caricion fuscae) with interspersed Eriophorum scheucherzi as character species, on the other hand the calcareous fen (Caricion davallianae) with Primula farinosa as character species. In the course of our study, Carex bicolor and Carex maritima could not be detected, despite multiple inspections. According to Steiner (2002) and Info Flora (2018), these character species (C. bicolor: dominant, C. maritima: rare) of the alluvial banks should occur at the Riffel Lake. This would have made a small-scale assignment to the Caricion bicolori-atrofuscae Nordhagen 1937 (alluvial bank) possible. It is not clear whether the absence of the species in the surveys and inspections of this work is subject to an observer bias or is due to an actual change in the vegetation during the 1.5 decades. The complete absence of snow bed communities in Steiner's (2002) work is probably due to the generalization in the mapping process. The abundance of snow beds in the perimeter, with Alchemilla pentaphyllea (character species) as well as Salix herbacea and Sibbaldia procumbens (characteristic species), can be assumed also for 2002.

\section{Conservation value}

With the above described assignment of the two fen types and the snow bed to the alliance Salicion herbaceae (Carex foetida and Alchemilla pentaphyllea), the question of protected habitats in the study area can be answered positively (Delarze et al. 2015). According to the Red List of Habitats (Delarze et al. 2016), both fen types are vulnerable (VU), while the other three vegetation units fall into the category LC (least concern). According to the Swiss Nature and Cul- 


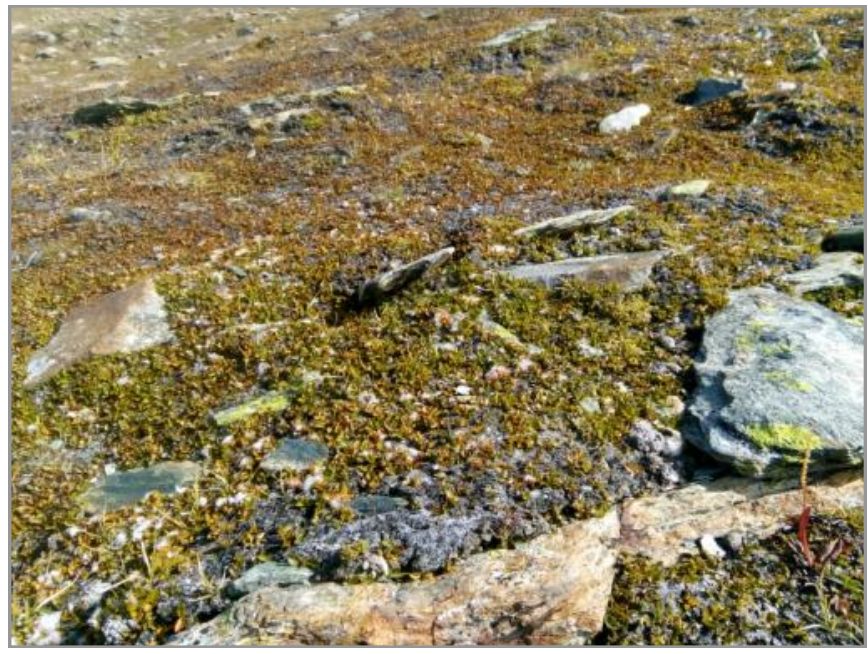

Fig. 11. Stand of the Salicion herbacae with typical carpet -like growth of the low Salix herbacea. Photo: J. Pachlatko 2018.

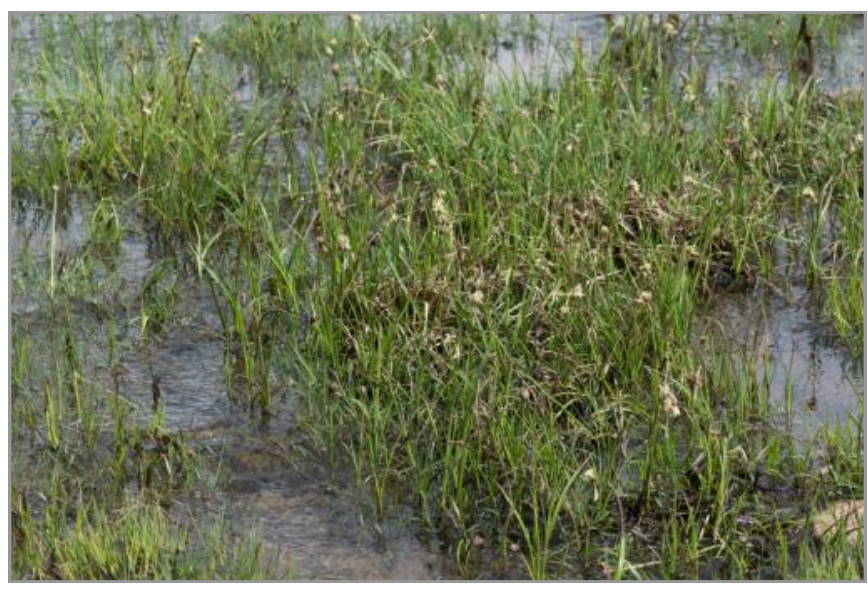

Fig. 12. Shore vegetation with Eriophorum angustifolium at the Riffel lake. The vegetation unit coded as "fen acid" was assigned to the Caricion fuscae. Photo: J. Dengler 2018.

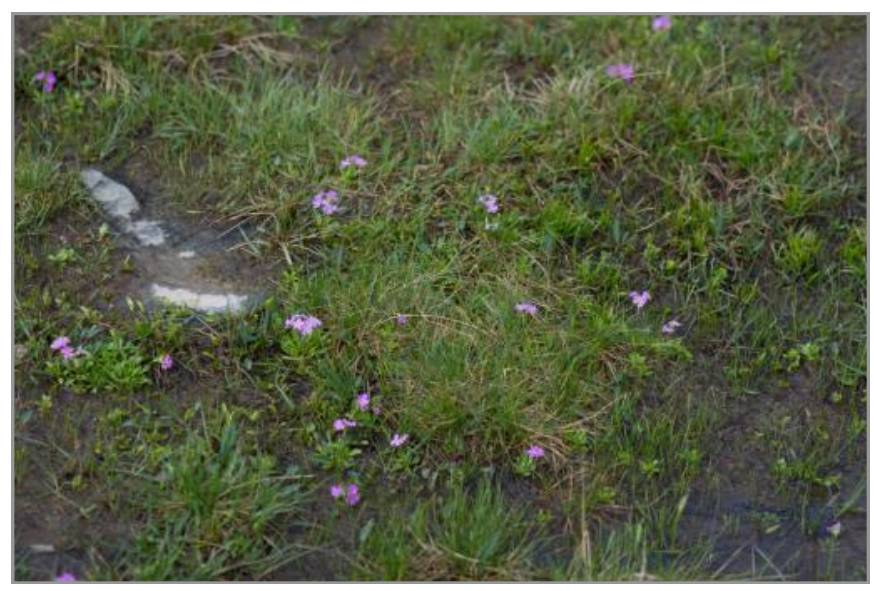

Fig. 13. Example of an area coded as "fen alkaline" in the discharge of the Riffel lake. The assignment to the alliance Caricion davallianae was based on the species Primula farinosa. Photo: J. Dengler 2018. tural Heritage Ordinance, both the fens and the snow beds are all protected (Art. 14, para. 3, Annex 1, NHV 2017). As described in the Results, also a few protected and endangered species can be found in the study area. The diversity and rarity of the plants in this area, concentrated in a small area, is of great floristic value (Käsermann et al. 2003) and conflicts with the high visitor frequency (Whinam \& Chilcott 2003; Mason et al. 2015). The overuse of nature as a tourist resource often results in the loss of local biodiversity and landscape quality (Holden 2016).

The analyses of orthophoto series of the Riffel Lake (years 1882-2015) show a continuous degradation of the shore and fen vegetation (for details, see Pachlatko 2018). The integration into a BLN protected area and the floristic values surveyed raise the question of appropriate protection. The Swiss Federal Inventory of Landscapes and Natural Monuments (BLN) calls for the preservation of the untouched character of natural and wild habitats (BAFU 2017). The Swiss Federal Ordinance on Nature and Cultural Heritage also makes it clear that biotopes are protected among other things by "design measures that can achieve the protection objective, repair existing damage and prevent future damage" (Art. 14, Para. 2c, NHV 2017). Due to the situation (deterioration of the vegetation condition, visitor frequency), the authors therefore recommend a visitor management system with measures such as user-specific trails that does justice to the protection objectives of the area.

\section{Recommendations for the "Gornergrat concept"}

For the "Gornergrat concept", it is recommended to adapt the planned route changes in the study area based on the vegetation mapping of our study (for details, see Pachlatko 2018). In particular, the routing in subarea 2 (path section) should be shifted because the planned mountain bike trail leads through a stand of the Salicion herbaceae (snow bed, protected according to NHV 2017), and the planned new hiking trail to be approved would be very close to it (Pachlatko 2018). The strong tourist attraction of the eastern lake shore (very scenic point for photographers with lake in the foreground and Matterhorn in the background) was included in the project with the planned construction of a viewing platform. Our findings support such a solution. A landscape-friendly viewing platform on the lake shore, combined with attractive visitor information, could greatly reduce the pressure of use on the shore vegetation. Also recommended are the path changes planned by the project around the Riffel Lake, as they take into account the sensitive fens that occur here. Throughout the project area, it is also recommended to restore the informal paths in order to avoid further erosion.

In order to reduce the pressure of use on the flora and vegetation of the area, steering measures are required to keep the flow of visitors on the paths and give the habitats around the Riffel Lake a chance to regenerate. Sensitive areas are to be bypassed with lead structures. Due to the strong degradation of the eastern shore of the Riffel lake, it is recommended that visitors be kept away and that the shore be restored during the project. Here, the roughening 


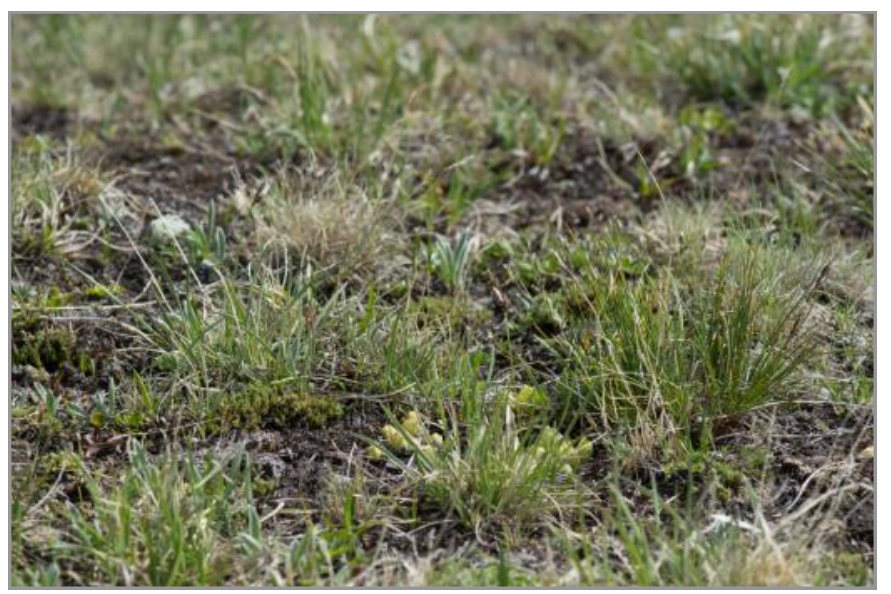

Fig. 14. Example of the vegetation type coded as "meadow" with dominating Festuca halleri. It belongs to the alliance Caricion curvulae. Photo: J. Dengler 2018.

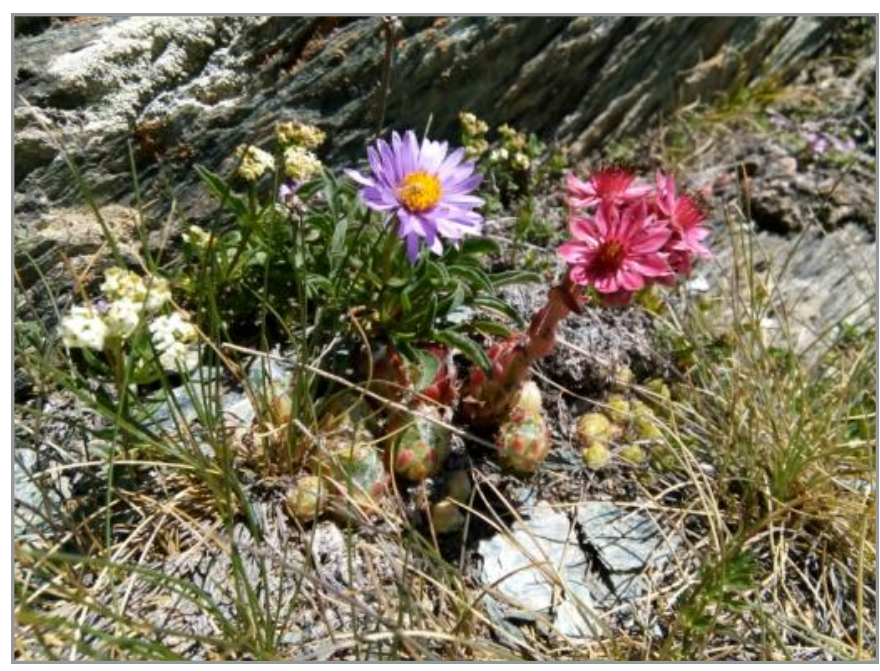

Fig. 15. Rocky subtype of the alliance Caricion curvulae with Erigeron alpinus, Sempervivum arachnoideum and Festuca halleri. It inhabits the driest sites of the study area. Photo: J. Pachlatko 2018.

of the most disturbed areas in the shore area is superficially necessary in order to make plant growth possible again. By preserving the area from trampling, the Riffel Lake shore could regain its original character.

\section{Author contributions}

This publication is based on the Bachelor thesis of J.P., which was supervised by J.D. and M.W. J.P. sampled the data, ran the analyses, planned the paper and led the writing, while J.D. and M.W. revised and approved the text.

\section{Acknowledgements}

Our thanks go to Gabriela Keusch from BikePlan AG, who introduced J.P. to Zermatt, Stefan Widmer from the Vegetation Ecology Group, who patiently dealt with all kinds of questions, and Barbara Blank for editing the Bachelor thesis. We are grateful to Riccardo Guarino for his fast and con- structive editorship and review of the manuscript and likewise to Lorna Marcham for her competent linguistic editing.

\section{References}

BAFU 2011. Liste der National Prioritären Arten. Arten mit nationaler Priorität für die Erhaltung und Förderung, Stand 2010. Bundesamt für Umwelt [Umwelt-Vollzug Nr. 1103], Bern, CH.

BAFU 2017. BLN Nr. 1707 Dent Blanche, Matterhorn, Monte Rosa. URL: https://data.geo.admin.ch/ch.bafu.bundesinventare-bln/ objectsheets/2017revision/nr1707.pdf [accessed 27 July 2018].

Barros, A. \& Marina Pickering, C. 2017. How networks of informal trails cause landscape level damage to vegetation. Environmental Management 60: 57-68.

Bilz, M., IUCN Regional Office for Europe \& IUCN Species Survival Commission (eds.) 2011. European red list of vascular plants. Publications Office of the European Union. Luxembourg, LU.

Bornand, C., Gygax, A., Juillerat, P., Jutzi, M., Möhl, A. \& Rometsch, S. 2016. Rote Liste Gefässpflanzen. Gefährdete Arten der Schweiz. BAFU and InfoFlora, Bern and Geneva, $\mathrm{CH}$.

Braun-Blanquet, J. 1920. Observations sur la végétation et sur la flore des environs de Zermatt (1919-1920). Bulletin de la Murithienne 41: 18-55.

Braun-Blanquet, J., Pallman, H. \& Bach, R. 1954. Pflanzensoziologische und bodenkundliche Untersuchungen im schweizerischen Nationalpark und seinen Nachbargebieten. Lüdin, Liestal, $\mathrm{CH}$.

Bruelheide, H. 2000. A new measure of fidelity and its application to defining species groups. Journal of Vegetation Science 11: 167 $-178$.

BVZ Holding AG 2017. BVZ Holding annual report. 2017. URL: https://www.bvzholding.ch/de/investoren/berichterstattung/ geschaeftsberichte [accessed 20 September 2018].

Chytrý, M. 2007. Project vegetation of the Czech Republic: Preface and summary of methods. In: Chytrý, M. (ed.) Vegetation of the Czech Republic 1. Grassland and heathland vegetation, pp. 3552. Academia, Prague, CZ.

Chytrý, M., Tichý, L., Holt, J. \& Botta-Dukát, Z. 2002. Determination of diagnostic species with statistical fidelity measures. Journal of Vegetation Science 13: 79-90.

Corrodi, D. 2011. Einfluss der touristischen Nutzung auf die Pioniervegetation am Grünsee im Gletschervorfeld des Grossen Aletschgletschers - Analyse des Trittfaktors und Vorschläge für die Besucherlenkung. Master thesis, Geographical Institute, University of Zurich, Zurich, $\mathrm{CH}$.

Delarze, R., Gonseth, Y., Eggenberg, S. \& Vust, M. 2015. Lebensräume der Schweiz: Ökologie - Gefährdung - Kennarten. 3rd ed. Ott, Bern, $\mathrm{CH}$.

Delarze, R., Eggenberg, S., Steiger, P., Bergamini, A., Fivaz, F. \& Gonseth, Y. 2016. Rote Liste der Lebensräume der Schweiz. Updated Summary of the Technical Report 2013 on behalf of the Federal Office for the Environment (BAFU). BAFU, Bern, $\mathrm{CH}$.

Dengler, J., Chytrý, M. \& Ewald, J. 2008. Phytosociology. In: Jørgensen, S.E. \& Fath, B.D. (eds.) Encyclopedia of ecology, pp. 27672779. Elsevier, Oxford, UK.

Dengler, J., Boch, S., Filibeck, G., Chiarucci, A., Dembicz, I., Guarino, R., Henneberg, B., Janišová, M., Marcenò, C., (...) \& Biurrun, I. 2016. Assessing plant diversity and composition in grasslands across spatial scales: the standardised EDGG sampling methodology. Bulletin of the Eurasian Grassland Group 32: 13-30.

Dierschke, H. 1994. Pflanzensoziologie - Grundlagen und Methoden. Ulmer, Stuttgart, DE.

Eagles, P.F.J., McCool, S.F. \& Haynes, C.D. 2002. Sustainable tourism in protected areas: guidelines for planning and management. IUCN, Gland, $\mathrm{CH}$. 
Eggenberg, S. \& Möhl, A. 2013. Flora Vegetativa. 3rd ed. Haupt, Bern, $\mathrm{CH}$.

Eggenberg, S., Bornand, C., Juillerat, P., Jutzi, M., Möhl, A., Nyffeler, R. \& Santiago, H. 2018. Flora Helvetica - Exkursionsführer. Haupt, Bern, $\mathrm{CH}$.

Ellenberg, H. \& Leuschner, C. 2010. Vegetation Mitteleuropas mit den Alpen in ökologischer, dynamischer und historischer Sicht. 6th ed. Ulmer, Stuttgart, DE.

Ewald, J. 2003. A critique for phytosociology. Journal of Vegetation Science 14: 291-296.

Glavac, V. 1996. Vegetationsökologie - Grundfragen, Aufgaben, Methoden. Fischer, Jena, DE.

Gnägi, C. \& Labhart, T.P. 2015. Geologie der Schweiz. 9th ed. Ott, Bern, $\mathrm{CH}$.

Grabherr, G. \& Mucina, L. (eds.) 1993. Die Pflanzengesellschaften Österreichs. Teil 2: Natürliche waldfreie Vegetation. Fischer, Jena, DE.

Hill, M.O. 1979. TWINSPAN - A FORTRAN program for arranging multivariate data in an ordered two-way table by classification of the individuals and attributes. Cornell University, New York, US.

Holden, A. 2016. Environment and tourism. 3rd ed. Routledge, New York, US.

IMBA 2004. Trail solutions IMBA's guide to building sweet singletrack - International Mountain Bicycling Association. Publication Printers Corp., Boulder, US.

Info Flora 2018. Das nationale Daten- und Informationszentrum der Schweizer Flora. URL: https://www.infoflora.ch/en/ [accessed 20 September 2018]

Juillerat, P., Bäumler, B, Bornand, C., Eggenberg, S., Gygax, A., Jutzi, M., Möhl, A., Nyffeler, R., Sager, L. \& Santiago, H. 2017. Flora Helvetica Checklist 2017 der Gefässpflanzenflora der Schweiz. Info Flora, Bern, $\mathrm{CH}$.

Käsermann, C., Meyer, F. \& Steiner, A. 2003. Die Pflanzenwelt von Zermatt. Rotten, Visp, $\mathrm{CH}$.

Klötzli, F. 2001. Zur Biotopkartierung der Bergregionen - Eine vegetationskundliche Betrachtung. Sauteria 11: 9-25.

Landolt, E., Bäumler, B., Erhardt, A., Hegg, O., Klötzli, F., Lämmler, W., Nobis, M., Rudmann-Maurer, K., Schweingruber, F.H., (...) \& Wohlgemuth, T. 2010. Flora indicativa - Ökologische Zeiterwerte und biologische Kennzeichen zur Flora der Schweiz und der Alpen. 2nd ed. Haupt, Bern, $\mathrm{CH}$.

Lauber, K., Wagner, G. \& Gygax, A. 2018. Flora Helvetica. 6th ed. Haupt, Bern, $\mathrm{CH}$.

Mason, S., Newsome, D., Moore, S. \& Admiraal, R. 2015. Recreational trampling negatively impacts vegetation structure of an Australian biodiversity hotspot. Biodiversity and Conservation 24: 2685-2707.

MeteoSwiss. 2018. Bundesamt für Meteorologie und Klimatologie - Messwerte Gornergrat / Zermatt. URL: https:// shop. meteoswiss.ch/productView.html?type $=$ psc\&id $=17$ [accessed 25 August 2018].

Mucina, L., Bültmann, H., Dierßen, K., Theurillat, J.-P., Raus, T., Čarni, A., Šumberová, K., Willner, W., Dengler, J., (...) \& Tichý, L. 2016. Vegetation of Europe: Hierarchical floristic classification system of vascular plant, bryophyte, lichen, and algal communities. Applied Vegetation Science 19, Suppl. 1: 3-264.

NHV 2017. Verordnung über den Natur- und Heimatschutz (NHV) vom 16. Januar 1991 (Stand am 1. Juni 2017). URL: https:// w w w a d m in. ch/opc/de/clas s ified compilation/19910005/201706010000/451.1.pdf.

Pachlatko, J. 2018. Vegetationskartierung am Gornergrat. Bachelor thesis, IUNR, Zurich University of Applied Sciences, Wädenswil, CH. DOI: $10.21256 /$ zhaw-2364.

Pickering, C.M. \& Hill, W. 2007. Impacts of recreation and tourism on plant biodiversity and vegetation in protected areas in Australia. Journal of Environmental Management 85: 791-800.

Pignatti, E. \& Pignatti, S. 2014. Plant Life of the Dolomites - Vegetation Structure and Ecology. Springer, Heidelberg, DE.

Reisigl, H. \& Keller, R. 1994. Alpenpflanzen im Lebensraum - Alpine Rasen, Schutt- und Felsvegetation. 2nd ed. G. Fischer, Jena, DE.

Roleček, J., Tichỳ, L., Zelenỳ, D. \& Chytrỳ, M. 2009. Modified Twinspan classification in which the hierarchy respects cluster heterogeneity. Journal of Vegetation Science 20: 596-602.

Rupf, R. 2015. Planungsinstrumente für Wandern und Mountainbiking in Berggebieten - unter besonderer Berücksichtigung der Biosfera Val Müstair. Nationalpark-Forschung in der Schweiz. Haupt, Bern, $\mathrm{CH}$.

Sauerbier, H. \& Langer, W. 2017. Endemische Alpenpflanzen. Margraf Publishers, Weikersheim, DE.

Schubert, R., Hilbig, W. \& Klotz, S. 2010. Bestimmungsbuch der Pflanzengesellschaften Deutschlands. 2nd ed. Spektrum, Heidelberg, DE.

Steiner, A. 2002. Die Vegetation der Gemeinde Zermatt. Hochschulverlag AG ETH, Zürich, $\mathrm{CH}$.

swisstopo. 2018. Bundesamt für Landestopographie. GeoCover Vektordaten. URL: https://map.geo.admin.ch [accessed 27 July 2018].

Theurillat, J.-P., Aeschimann, D., Küpper, P., Spichinger, R. 1995. The higher vegetation units of the Alps. Colloques Phytosociologiques 23: 189-239.

Tichy, L. \& Chytry, M. 2006. Statistical determination of diagnostic species for site groups of unequal size. Journal of Vegetation Science 17: 809-818.

Tichý, L., Chytrý, M. \& Zelený, D. 2018. Juice Version 7.0.102. URL: http://www.sci.muni.cz/botany/juice/ [accessed 09 September 2018].

Whinam, J. \& Chilcott, N. M. 2003. Impacts after four years of experimental trampling on alpine / sub-alpine environments in western Tasmania. Journal of Environmental Management 67: 339-351.

Wimpey, J. F. \& Marion, J. L. 2010. The influence of use, environmental and managerial factors on the width of recreational trails. Journal of Environmental Management 91: 2028-2037.

WSL. 2017. VEGEDAZ. URL: https://www.wsl.ch/de/services-undprodukte/software-websites-und-apps/vegedaz-version2017.html [accessed 09 September 2018] 


\title{
Photo Story
}

\section{Kurgans of the Thracian kings - vegetation on the an- cient burial mounds of the Upper Thracian plain (Bulgaria)}

\author{
Balázs Deák ${ }^{1^{*}}$, Iva Apostolova ${ }^{2}$, András Kelemen ${ }^{3}$, Réka Kiss ${ }^{3}$, Katalin Lukács ${ }^{3}$, Salza Palpurina², \\ Desislava Sopotlieva ${ }^{2} \&$ Orsolya Valkó ${ }^{3}$
}

\author{
${ }^{1}$ MTA DE Biodiversity and Ecosystems Research Group, Egyetem tér 1, \\ Debrecen, 4032, Hungary \\ ${ }^{2}$ Institute of Biodiversity and Ecosystem Research, Bulgarian Academy of \\ Sciences, Sofia, 1113, Bulgaria.
}

Ancient burial mounds (the so-called kurgans) are widespread in the steppes and forest steppes of Eurasia and often act as refuges for dry grassland vegetation in transformed landscapes. Despite their high numbers (their estimated number is approximately 600,000 in Eurasia) and important conservation potential, their vegetation often remains unexplored in many regions. Bulgaria is a really exciting country for such studies as it holds approximately 15,000 kurgans dispersed in the fertile valleys and in the foothills of the mountains. Most of the kurgans in Bulgaria have been built by the Thracian tribes in the late Iron Age $\left(5^{\text {th }}\right.$ century B.C.). At the first sight, the huge mounds which are often higher than 10 metres seem like earthen hills, but under the surface there are amazing hidden sanctuaries. Given the fact that the steep slopes of the kurgans have not been ploughed, they often act as habitat islands with a semi -natural character in the seas of vast agricultural lands and harbour the last remnants of steppic vegetation. During our survey in May 2019, we aimed at exploring the vegetation of Bulgarian kurgans and the ecological processes shaping their species composition. In spite of the large level of landscape transformation, many of the steppic flora elements could survive in the presumably 2500-year-old grasslands preserved by the kurgans, such as Ranunculus illyricus, Goniolimon spp., Stipa spp., Elymus elongatus, Inula germanica, Taraxacum serotinum, Leontodon crispus, Hypericum rumeliacum and Inula ensifolia.

We are thankful for the financial support of the Bulgarian National Science Fund (Kח-06-H21/2) which makes the study of the vegetation of the Thracian mounds possible.
${ }^{3}$ MTA DE Lendület Seed Ecology Research Group, Egyetem tér 1, Debrecen, 4032, Hungary

*) Corresponding author: debalazs@gmail.com

The participation of the Hungarian researchers was partly supported by the NKFI KH 130338 grant.

For more information on kurgan studies, please visit the 'https://deakvalko.blogspot.com' research blog, where we regularly report the new results related to the study of kurgans. If you are interested in kurgans and would like to join to an Eurasia-wide project about building a kurgan database please contact Balázs Deák (debalazs@gmail.com) for more information.

\section{Publications related to the topic}

Deák, B., Tóthmérész, B., Valkó, O., Sudnik-Wójcikowska, B., Bragina, T.-M., Moysiyenko, I., Apostolova, I., Bykov, N., Dembicz, I. \& Török, P. 2016. Cultural monuments and nature conservation: The role of kurgans in maintaining steppe vegetation. Biodiversity \& Conservation 25: 24732490.

Deák, B., Valkó, O., Török, P. \& Tóthmérész, B. 2016. Factors threatening grassland specialist plants - A multi-proxy study on the vegetation of isolated grasslands. Biological Conservation 204: 255-262.

Deák, B., Valkó, O., Török, P., Kelemen, A., Bede, Á., Csathó, A.I. \& Tóthmérész, B. 2018. Landscape and habitat filters jointly drive richness and abundance of grassland specialist plants in terrestrial habitat islands. Landscape Ecology 33: 1117-1132.

Deák, B., Tóth, C.A., Bede, Á., Apostolova, I., Bragina, T.M., Báthori, F. \& Bán, M. 2019. Eurasian Kurgan Database a citizen science tool for conserving grasslands on historical sites. Hacquetia 18: 179-187. 


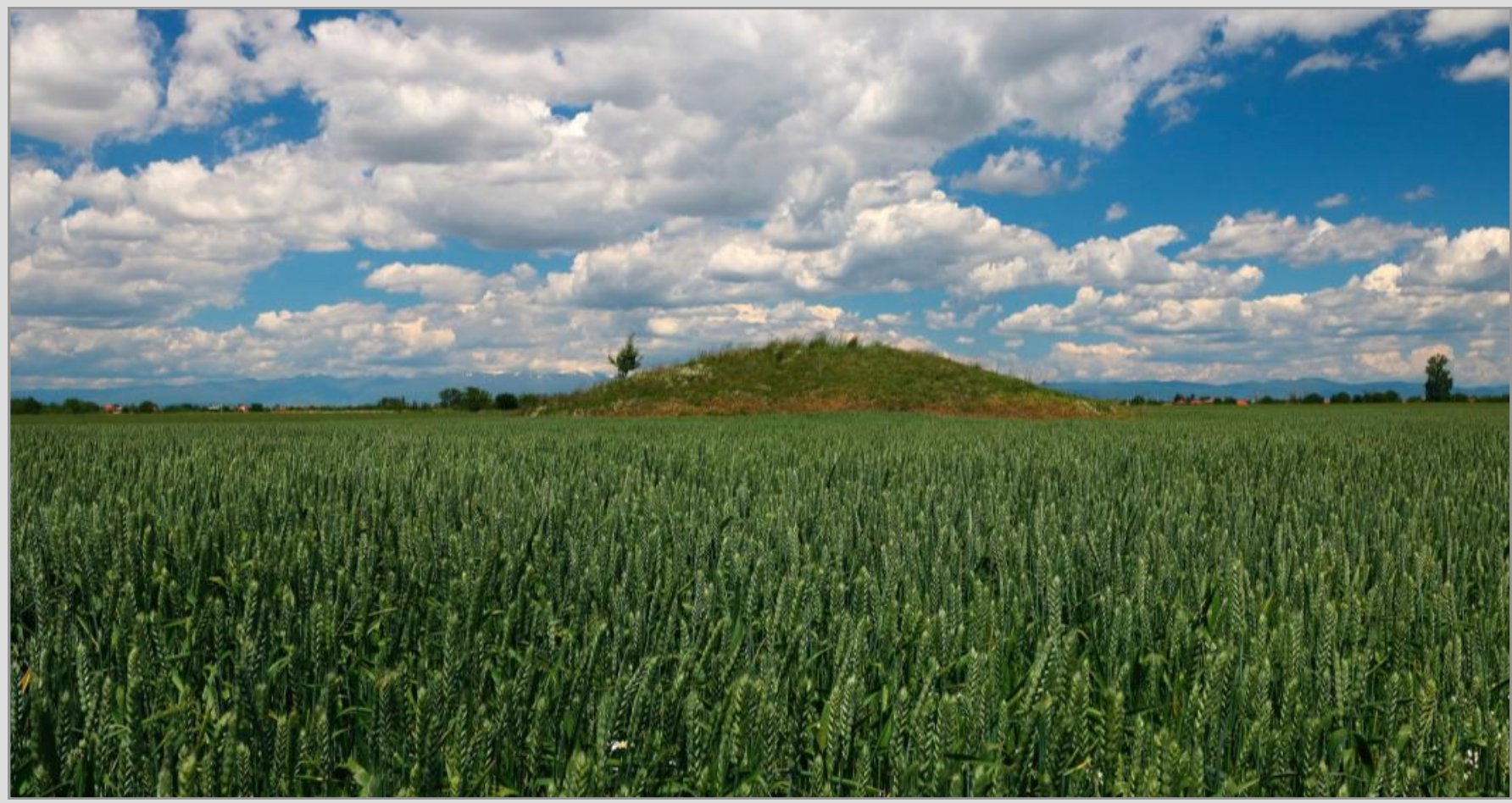

Grassland habitat island on a kurgan near to the village Rogosh. Photo: B. Deák.
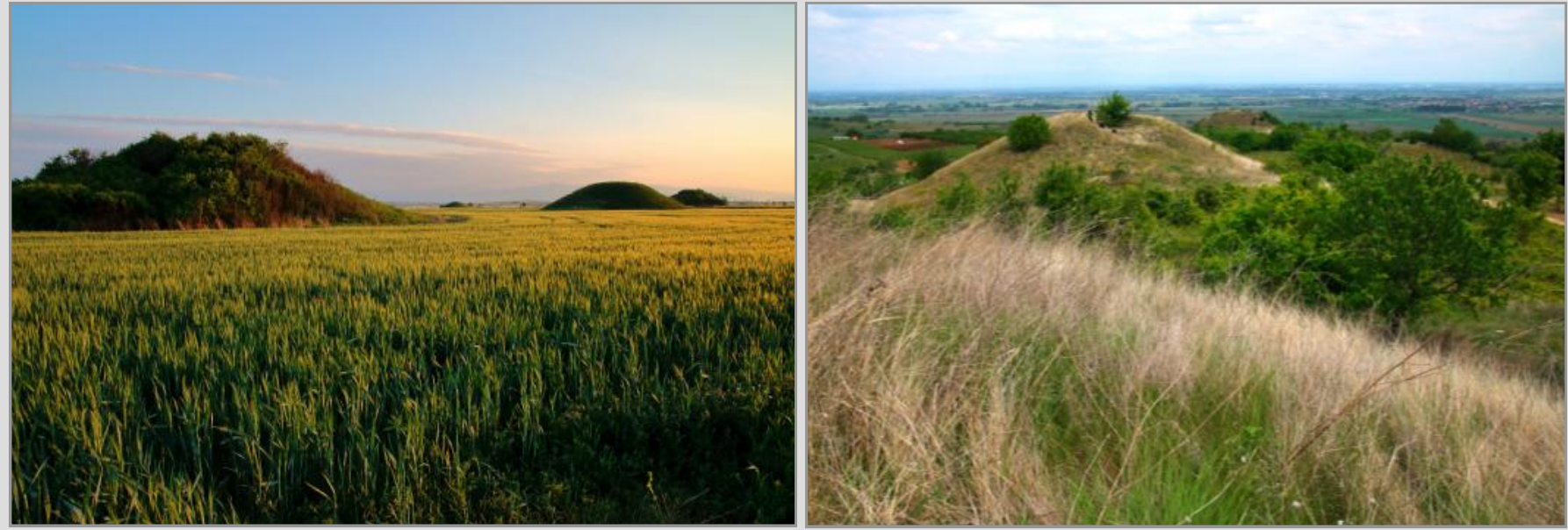

Kurgan groups on lowlands and on foothills. On the left a Thracian kurgan group surrounded by arable lands. On the right three kurgans embedded in orchards in the famous vine-growing region of Brestovica. Photos: B. Deák.

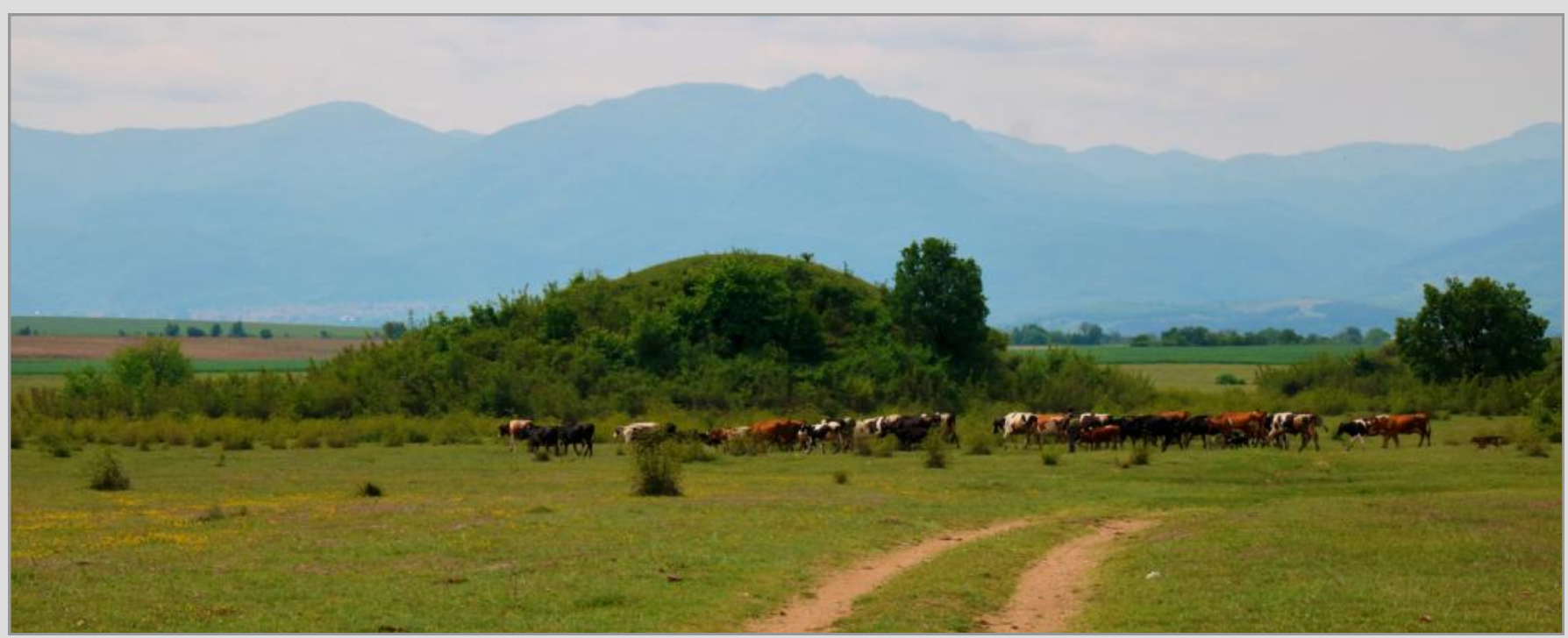

A rare case, when a kurgan is surrounded by grasslands. Photo: B. Deák. 

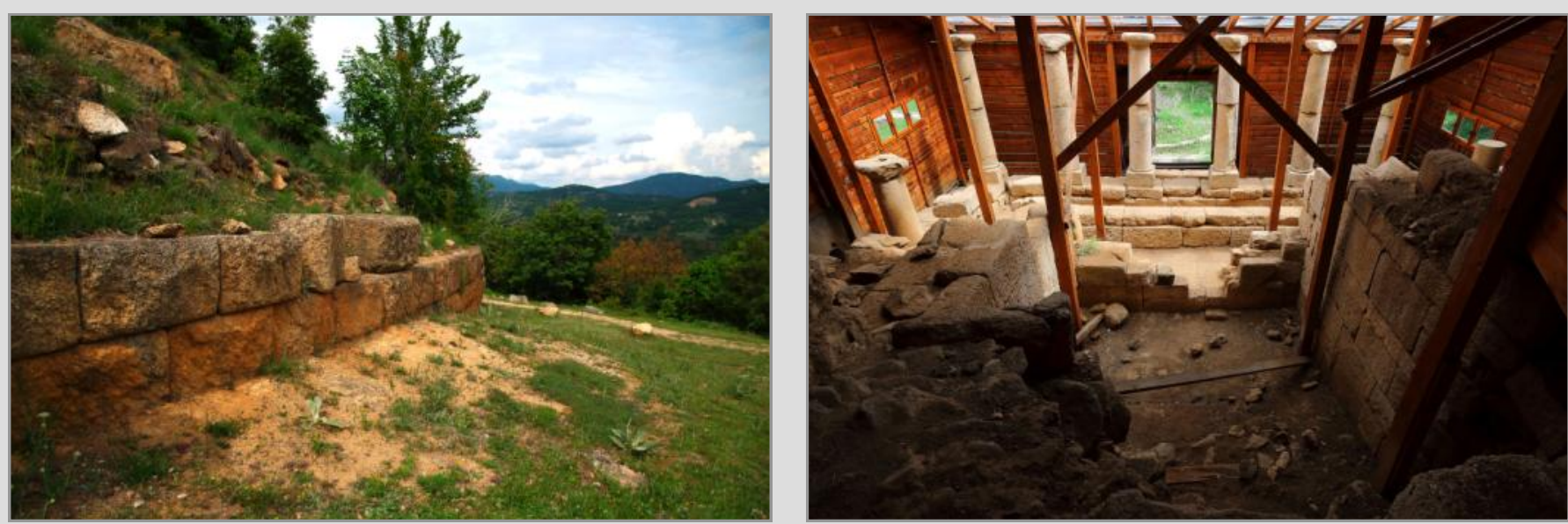

Kurgans are important monuments of our historical heritage. On the left the crepida (sacred stone wall) around the Starosel kurgan. On the right the excavated sanctuary of the Horizon kurgan. Photos: B. Deák.
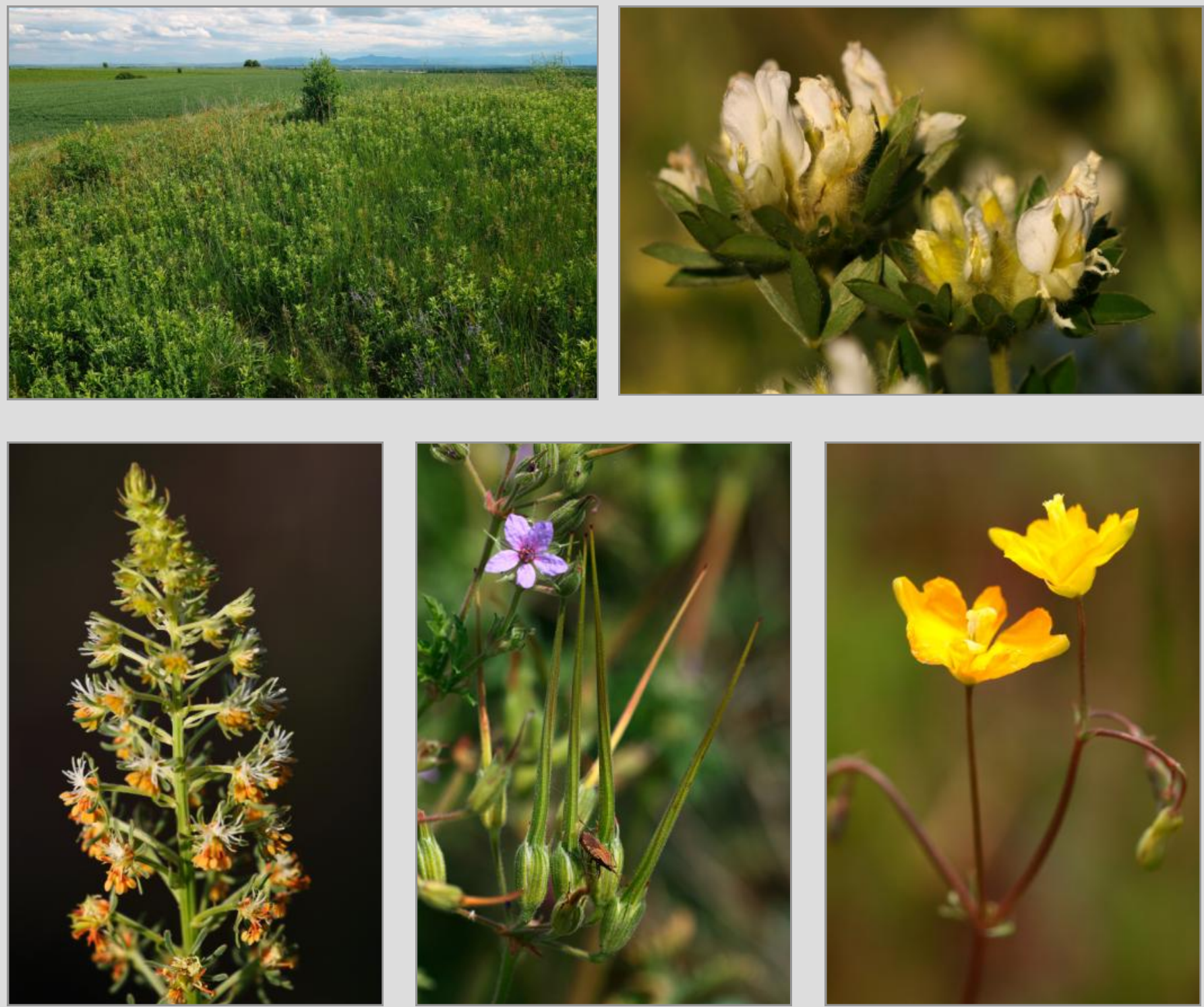

On the top left: kurgan covered by thousands of Inula germanica individuals with the Rodope mountains in the background. On the top right: Chamaecytisus albus is a frequent species of the Thracian mounds. Bottom left and middle: rare weed species: Reseda inodora and Erodium ciconium. Bottom right: Hypecoum pendulum. Photos: B. Deák. 

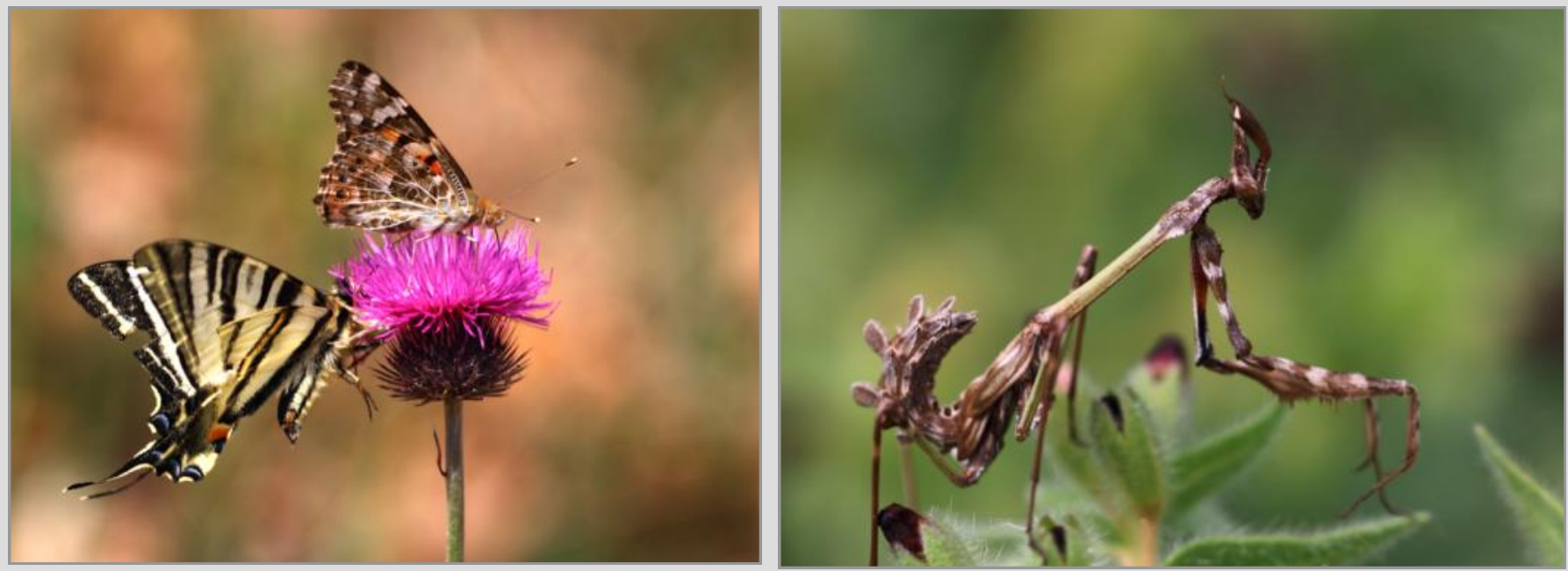

Kurgans also provide habitats for insect species. On the left colourful butterflies (Iphiclides podalirius and Vanessa cardui) on a thistle. On the right a juvenile Empusa species. Photos: B. Deák.

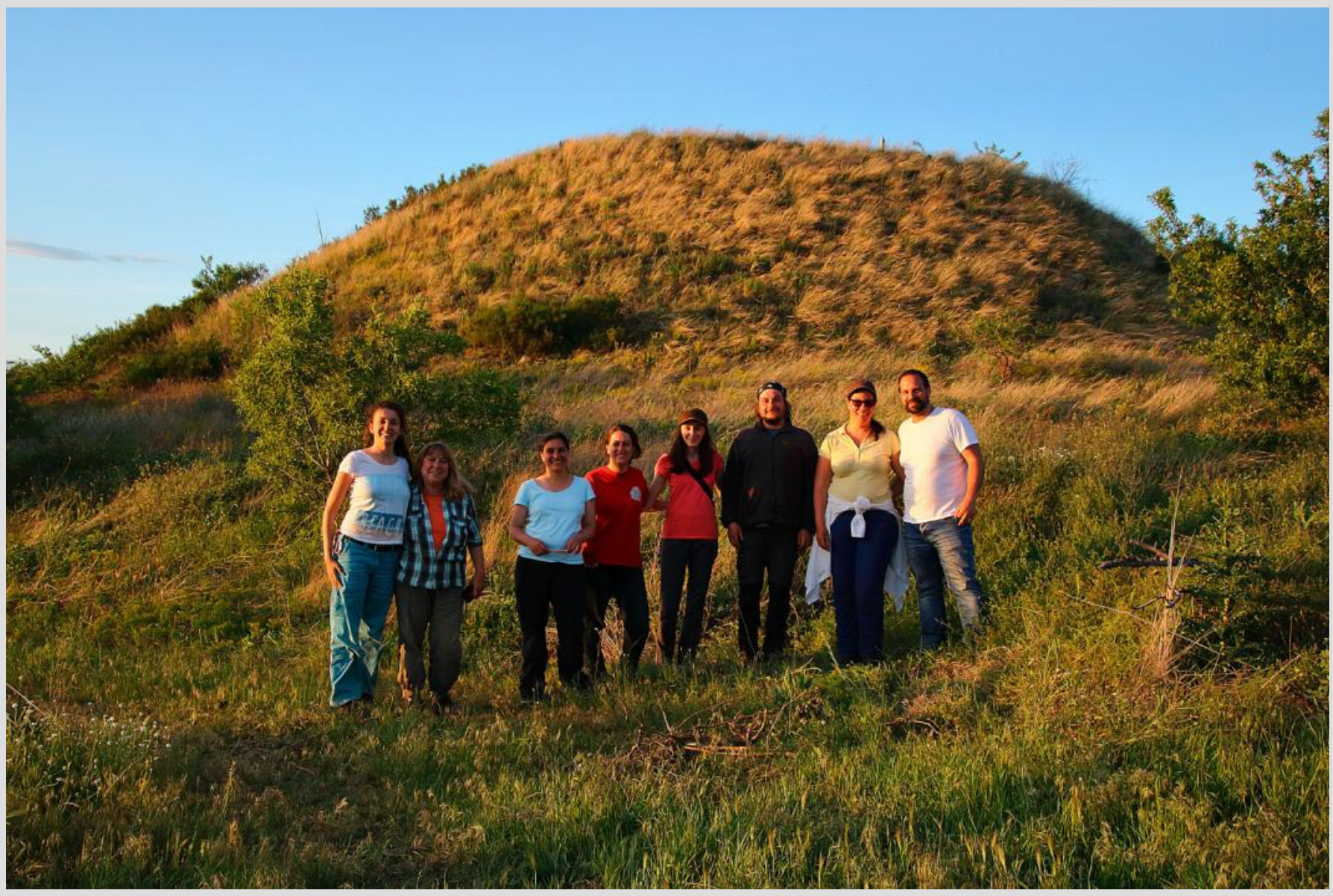

The surveyor team. From left to right: Salza Palpurina, Iva Apostolova, Desislava Sopotlieva, Réka Kiss, Katalin Lukács, András Kelemen, Orsolya Valkó and Balázs Deák. Photo: B. Deák. 

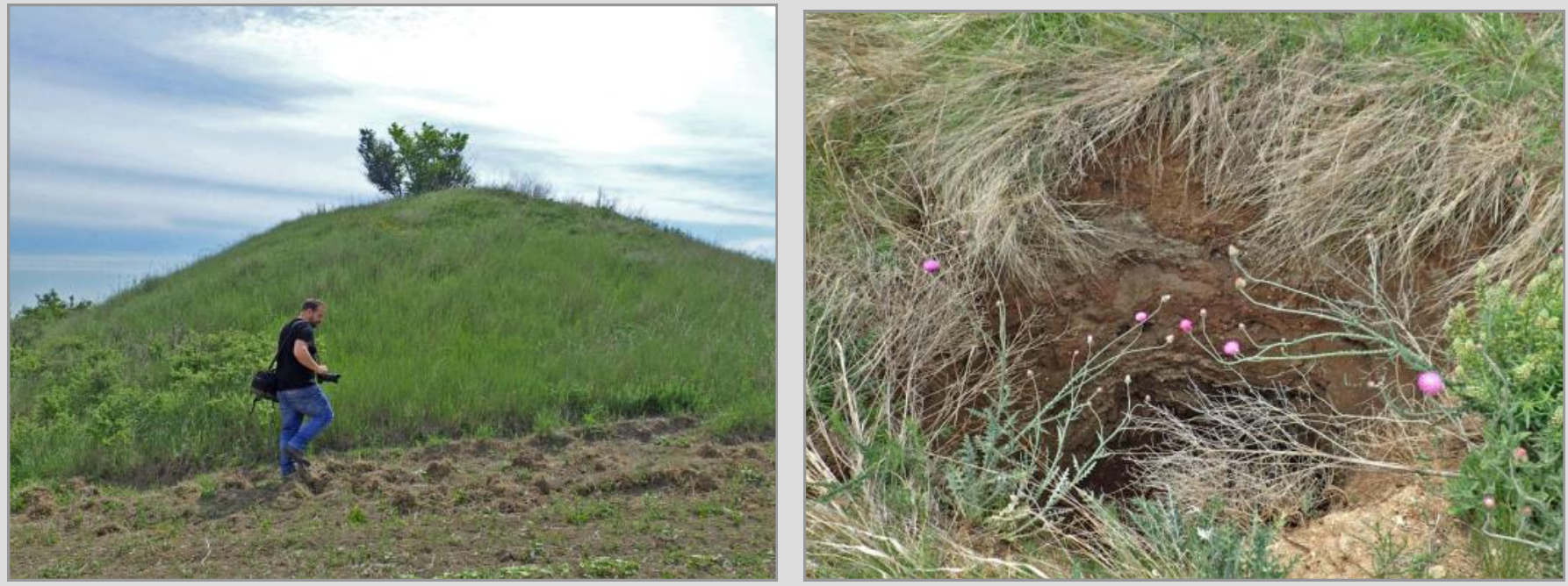

A common view is a grassy kurgan with a single tree or shrub on its top or side (on the left). And the reason? Excavations for gold by tomb raiders hold sufficient water and provide a milder environment to support the growth of trees (on the right). Excavated kurgans are vulnerable to shrub overgrowing and could thus lose their importance as a grassland habitat. Photos: S. Palpurina.

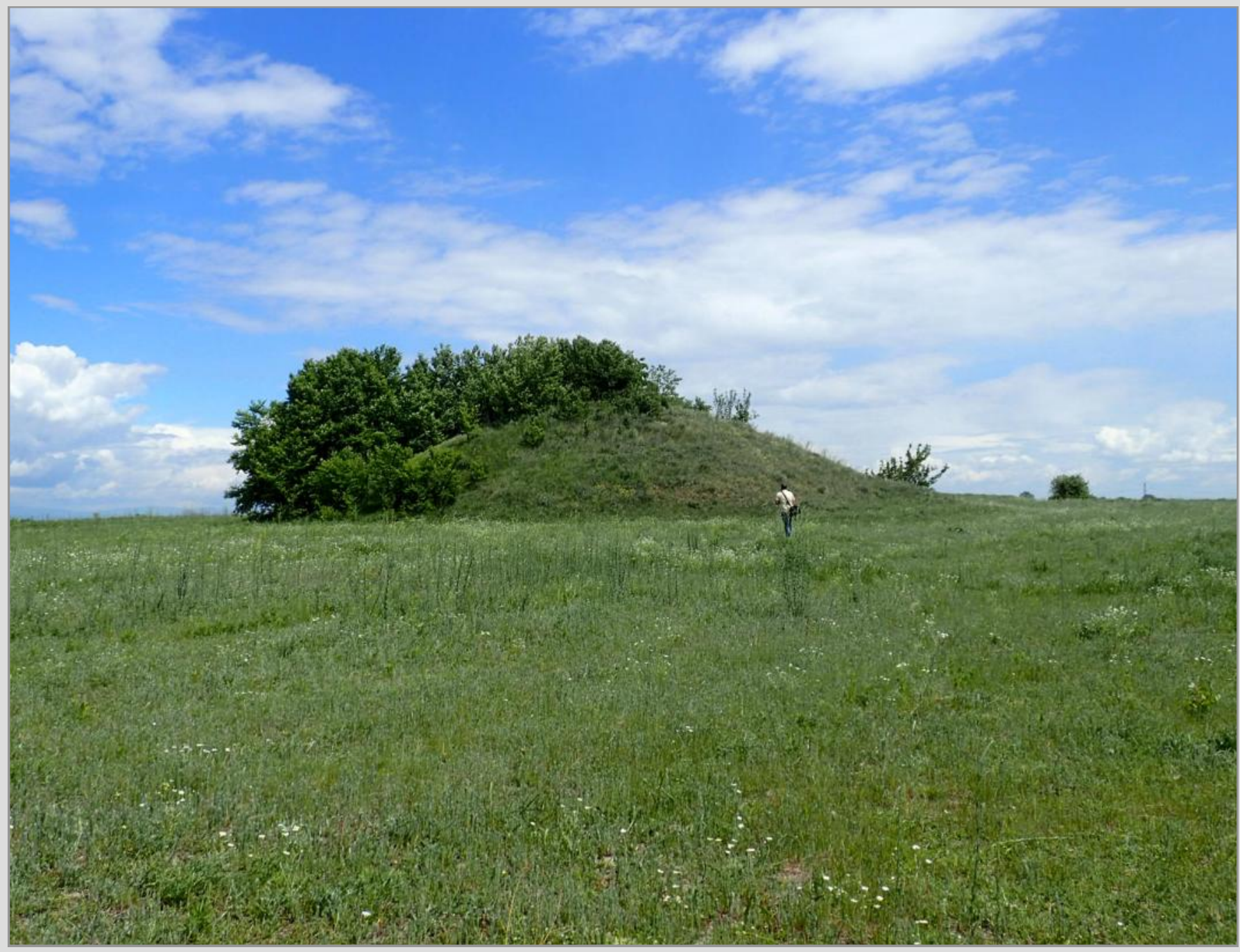

Kurgans are a mini forest-steppe ecosystem. Their more humid northern slopes are often overgrown by shrubs such as Ulmus minor, whilst the drier southern slopes hold grasslands. Photo: S. Palpurina. 


\section{Short contribution}

\section{Gene-environment relation- ships in Calluna vulgaris: re- quest for help in sampling}

Heather (Calluna vulgaris) has a large geographic distribution in Europe and is dominant in heath ecosystems but also widespread in other grassland types and forests. Global change, i.e. land use change, pollution and climate change affect heath ecosystems. These threats resulted in various restoration efforts, including assisted migration, i.e. the translocation of heath from putatively "preadapted" southern populations to more northern sites that in future will experience similar climatic conditions. However, we do have very limited knowledge about the phylogeographic structure and patterns of genetic variation and its relation to environmental conditions across the range of Calluna vulgaris, that might inform such actions.

We therefore analyse the intraspecific genetic structure of Calluna vulgaris across its whole distribution range. We address intraspecific genetic relationships that resulted from both the history of colonisation and from evolutionary selection due to environmental conditions. Preliminary results of samples already available show phylogeographic patterns that partly match those known from other species (Fig. 1) and also indicate close gene-environment interactions.
The current sample allows a rather detailed view into the intraspecific genetic structure of Calluna vulgaris and also into gene environment interactions. However, the picture should be refined with additional samples. This is particularly important first for the suture zones of putative genetic clusters identified, i.e. regions in which two cluster adjoin, e.g. Eastern France, East of England, Southern Norway and Sweden. Second, more samples should be added in underor unsampled regions, e.g. Iberian peninsula, Balkans, Carpathians, Northern Scandinavia, and in particular Eastern Europe.

Therefore we would like to ask for help in sampling Calluna vulgaris, from geographic areas not yet covered. Sampling is easy and does not necessitate any special skill or device. As we sample across the whole range and our resources are limited, the distance between adjacent sampling sites will generally be $>100 \mathrm{~km}$. Thus, if you consider to collect, please first get in contact with WD and/or consult the map of sites already sampled https://drive.google.com/open? id=1bvc2r39825P InhyWYNOqt-ssko\&usp=sharing. Details on sample collection are also given at https://www.ufz.de/ index.php?de=43305.

Walter Durka, Halle (Saale), Germany walter.durka@ufz.de
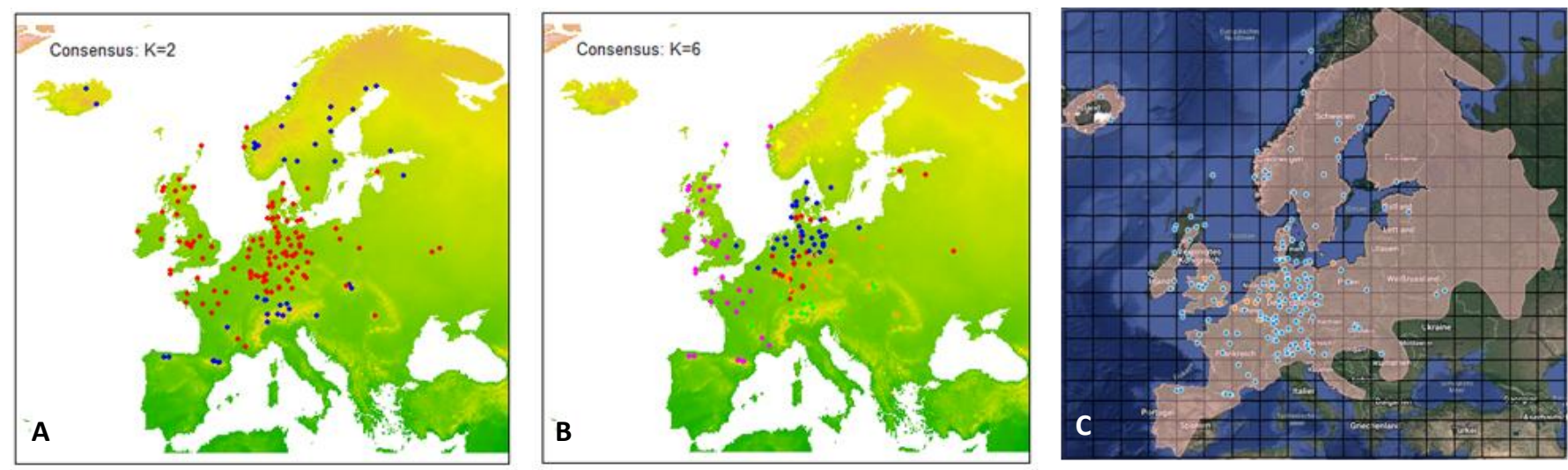

Fig. 1. Spatial structure of intraspecific genetic groups derived from SNP data of Calluna vulgaris populations (Durka unpublished) for either $\mathrm{K}=\mathbf{2}(\mathrm{A})$ or $\mathrm{K}=6$ (B) assumed clusters. Distribution range of Calluna vulgaris, showing large regions that are not yet sampled (C). 


\section{Recent Publications of our Members}

In this section, the contents of which will also be made available via our homepage, we want to facilitate an overview of grassland-related publications throughout Eurasia and to improve their accessibility. You are invited to send lists of such papers from the last three years following the format below to Iwona Dembicz, i.dembicz@gmail.com. We will include your e-mail address so that readers can request a pdf. For authors who own full copyright, we can also post a pdf on the EDGG homepage.

\section{Conservation and restoration}

Karlík, P. \& Poschlod, P. (2019). Identifying plant and environmental indicators of ancient and recent calcareous grasslands. Ecological Indicators 104: 405-421.

\section{Ecology}

Dengler, J., Matthews, T.J., Steinbauer, M.J., Wolfrum, S., Boch, S., Chiarucci, A., Conradi, T., Dembicz, I., Marcenò, C., García-Mijangos, I., Nowak, A., Storch, D., Ulrich, W., Campos, J.A., Cancellieri, L., Carboni, M., Ciaschetti, G., De Frenne, P., Dolezal, J., Dolnik, C., Essl, F., Fantinato, E., Filibeck, G., Grytnes, J.-A., Guarino, R., Güler, B., Janišová, M., Klichowska, E., Kozub, Ł., Kuzemko, A., Manthey, M., Mimet, A., Naqinezhad, A., Pedersen, C., Peet, R.K., Pellissier, V., Pielech, R., Potenza, G., Rosati, L., Terzi, M., Valkó, O., Vynokurov, D., White, H., Winkler, M. \& Biurrun, I. 2019. Species-area relationships in continuous vegetation: Evidence from Palaearctic grasslands. Journal of Biogeography [in press]. doi: 10.1111/ jbi.13697.

Palpurina, S., Chytrý, M., Hölzel, N., Tichý, L., Wagner, V., Horsák, M., Axmanová, I., Hájek, M., Hájková, P., Freitag, M., Lososová, Z., Mathar, W., Tzonev, R., Danihelka, J. \& Dřevojan, P. 2019. The type of nutrient limitation affects the plant species richness-productivity relationship: Evidence from dry grasslands across Eurasia. Journal of Ecology 107: 1038-1050. doi: 10.1111/1365-2745.13084

Filibeck, G., Sperandii, M.G., Bazzichetto, M., Mancini, L.D., Rossini, F. \& Cancellieri, L. 2019. Exploring the drivers of vascular plant richness at very fine spatial scale in subMediterranean limestone grasslands (Central Apennines, Italy). Biodiversity and Conservation 28: 2701-2725.

Partzsch, M. 2019. Warming differently affects the interand intraspecific interactions among semi-dry grassland species. Perspectives in Plant Ecology, Evolution and Systematics 40 [in press]. doi.org/10.101/ j.ppees.2019.125481

\section{Flora}

Filibeck, G., Cancellieri, L., Bartolucci, F., Becker, U., Conti, F., Maestri, S., Mürz, M., Schommer, E., Sperandii, M.G. \& Becker T. 2019. Festuca valesiaca Schleich. ex Gaudin newly discovered in the Central Apennines (Italy): a further example of steppe relict in the Abruzzo "dry valleys". Plant Biosystems [in press]. doi: 10.1080/11263504.2019.1651784

\section{Contact persons:}

Jürgen Dengler: juergen.dengler@uni-bayreuth.de

Goffredo Filibeck: filibeck@unitus.it

Petr Karlik: PKarlik@seznam.cz

Salza Palpurina: salza.palpurina@gmail.com

Monika Partzsch: monika.partzsch@botanik.uni-halle.de

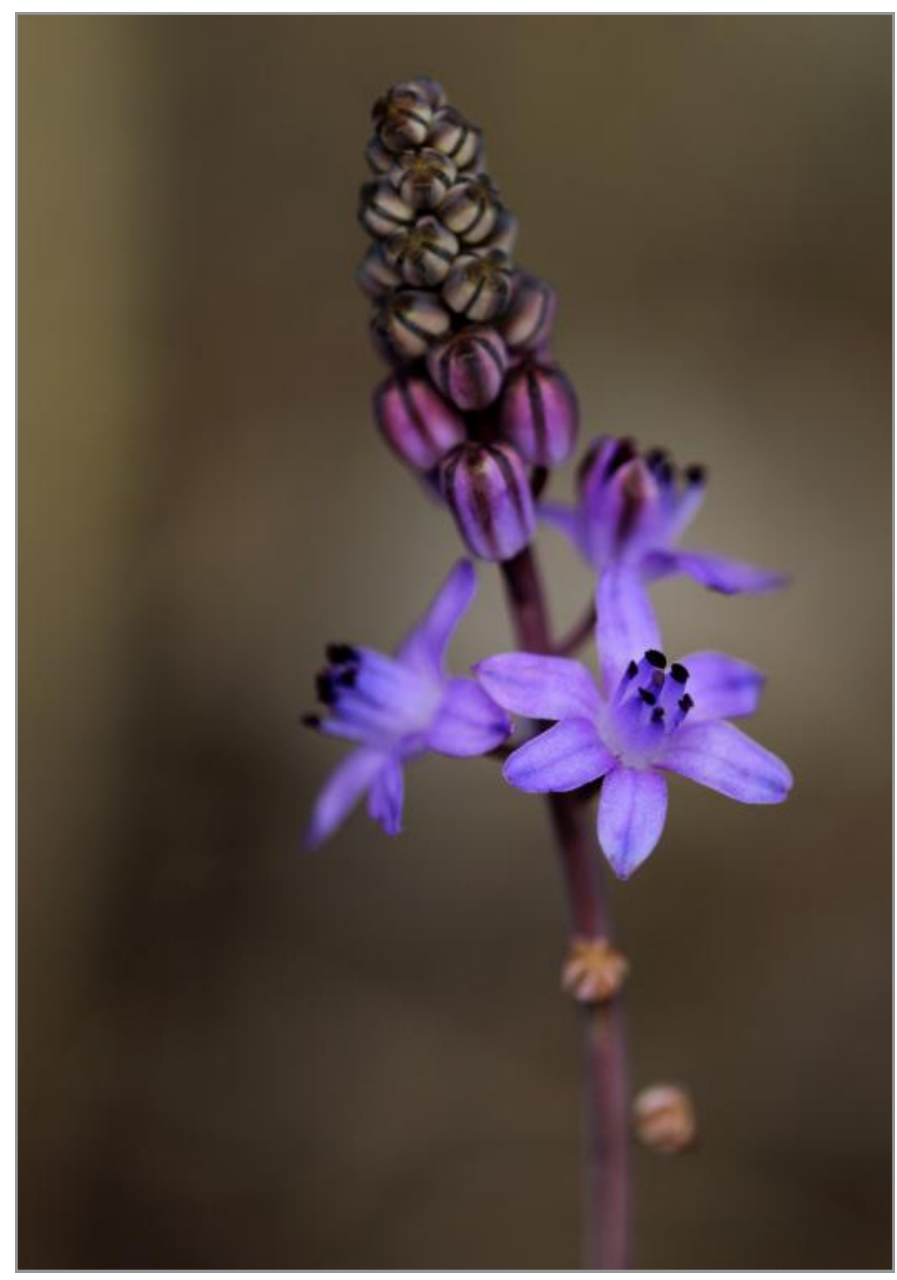

Scilla autumnalis, Prespes, NW Greece. Photo: P. Chmielewski. 


\section{Forthcoming Events}

World Conference of the Ecosystem Service Partnership 21-25 October 2019 in Hannover, Germany, with UFZ/iDiv as co-organisers

Conference website: https://www.espconference.org/esp10

Meeting of the FAO-CIHEAM Networks on Sheep and Goats and Mediterranean Pastures

23-25 October 2019 in Meknes, Morocco

Conference website: http://networks.iamz.ciheam.org/ meknes2019/en/index.php

International symposium on Reproductive strategies from genes to societies - Frontiers in animal and plant reproduction research

7-9 November 2019, Debrecen, Hungary

Symposium website http://konferencia.unideb.hu/en/ node/304

\section{British Ecological Society Annual Meeting 2019}

10-13 December 2019 in Belfast, Northern Ireland

Conference website: https:// www.britishecologicalsociety.org/events/annual-meeting2019/

The International Biogeography Society Early Career Conference

17-19 April 2020 in Amsterdam, the Netherlands

Conference website: https://www.biogeography.org/event/ early-career-conference-amsterdam/

\section{9th PLANTA EUROPA Conference}

11-15 May, Paris, France

Conference website: https://www.plantaeuropa.com/planta -europa-conference-2020

14th EDGG Field Workshop: Ukrainian steppes along climatic gradients

25 May - 3rd June 2020, Ukraine

See details in this issue, on pp. 6-7.

28th General Meeting of the European Grassland Federation

22-25 June 2020 in Helsinki, Finland

Conference website: www.egf2020.f

\section{2nd Quarries alive International Conference}

24-26 June 2020, Liege, Belgium

Conference website: http://www.gembloux.ulg.ac.be/ qa2020/

\section{3rd IAVS Symposium: Vegetation in the Anthropocene}

20-24 July 2020 , Vladivostok, Russia

Symposium website: http://geobotanica.ru/ symposium 2020/

$17^{\text {th }}$ Eurasian Grassland Conference: Grassland dynamics and conservation in a changing world

7-13 September 2020, Tolosa, Spain

See details in this issue, on pp. 8-13.

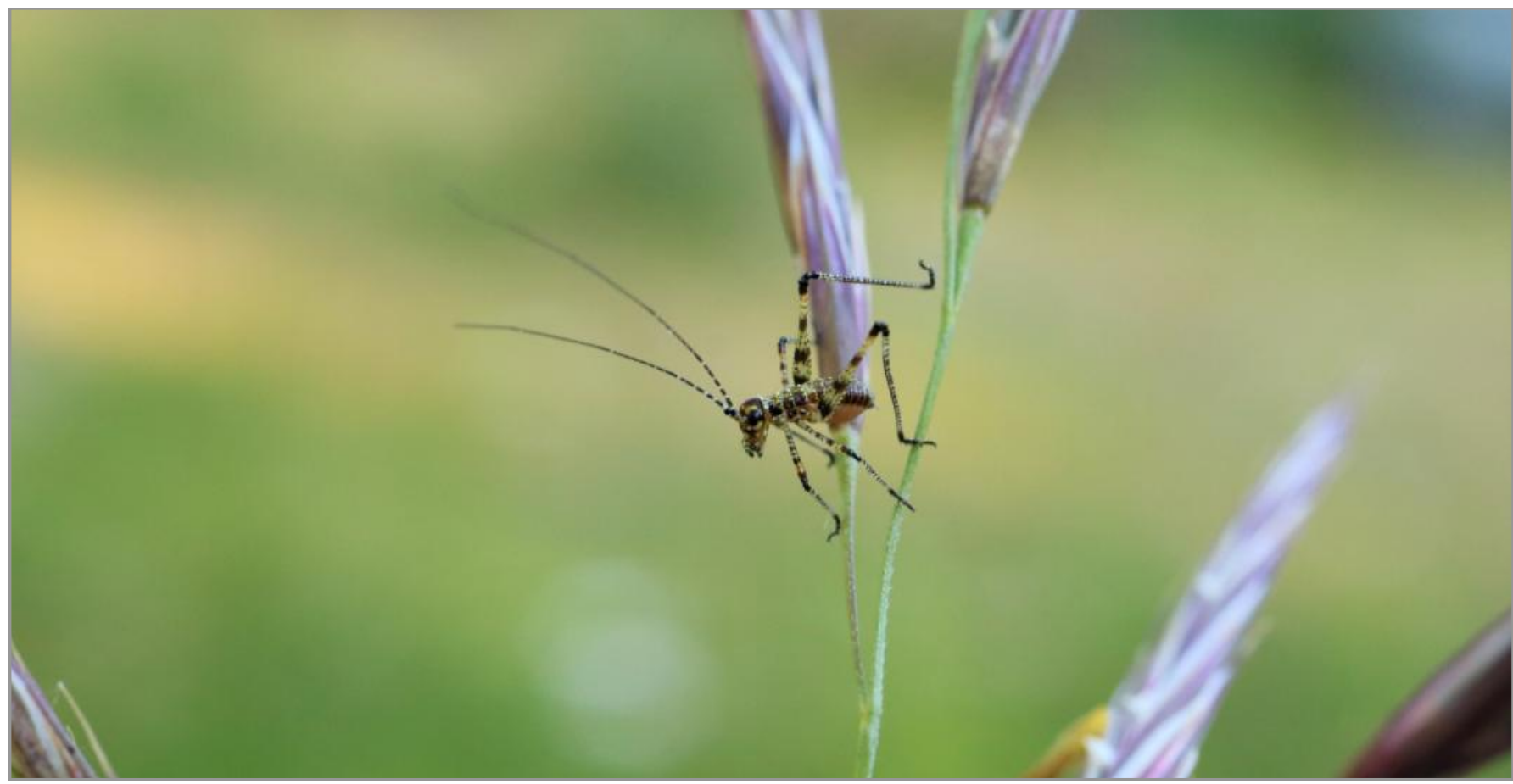

Juvenile cricket on Bromus erectus, Sankt Anna am Aigen, South-East-Styria, Austria. Photo: P. Sengl. 


\section{eDGG}

Grass[and]

research and conservation
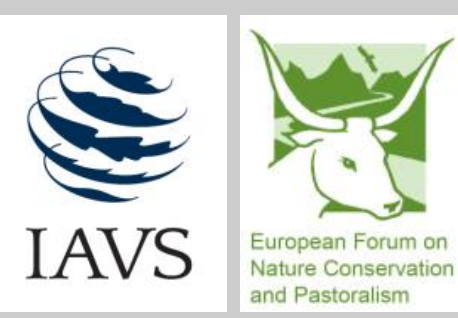

EDGG on the web:

http://www.edgg.org

EDGG in Facebook:

https://www.facebook.com/groups/938367279561202

EDGG on the ResearchGate

https://www.researchgate.net/project/EDGG-Eurasian-

DryGrassland-Group

The Eurasian Dry Grassland Group (EDGG), founded in 2008, is a working group of the International Association for Vegetation Science (IAVS) and member of the European Forum on Nature Conservation and Pastoralism (EFNCP). On 1 October 2019, it had 1314 members from 64 countries.

The Eurasian Dry Grassland Group (EDGG) is a network of researchers and conservationists interested in any type of Palaearctic natural and semi-natural grasslands. It is an official subgroup of IAVS (http://www.iavs.org) but one can join our group without being an IAVS member. We live from the activities of our members. Everybody can join the EDGG without any fee or other obligation.

The EDGG covers all aspects related to grasslands, in particular: plants - animals - fungi - microbia - soils - taxonomy - phylogeography - ecophysiology - population biology - species' interactions - vegetation ecology - syntaxonomy - landscape ecology - biodiversity - land use history - agriculture - nature conservation - restoration - environmental legislation - environmental education.

\section{EDGG Executive Committee and responsibilities of its members}

Alla Aleksanyan, Armenia, alla.alexanyan@gmail.com Chief Editor of the Website; Deputy Conference Coordinator; member of the Editorial Board of Palaearctic Grasslands

Didem Ambarlı, Germany, didem.ambarli@gmail.com Conference Coordinator; Deputy Chief Editor of the Website; member of the Editorial Board of Palaearctic Grasslands

Idoia Biurrun, Spain, idoia.biurrun@ehu.es

Membership Administrator; Deputy Chief Editor of Palaearctic Grasslands; Deputy Field Workshop Coordinator

Jürgen Dengler, Switzerland, juergen.dengler@uni-bayreuth.de

Secretary-General; Coordinator for Special Features; Deputy Chief Editor of Palaearctic Grasslands
Iwona Dembicz, Poland, i.dembicz@gmail.com

Field Workshop Coordinator; member of the Editorial Board of Palaearctic Grasslands

Anna Kuzemko, Ukraine, anyameadow.ak@gmail.com Chief Editor of Palaearctic Grasslands; Deputy Facebook Group Administrator

Péter Török, Hungary, molinia@gmail.com

IAVS Representative and Treasurer; Deputy Coordinator for Special Features; Deputy Secretary-General; member of the Editorial Board of Palaearctic Grasslands

Stephen Venn, Finland, stephen.venn@helsinki.fi Facebook Group Administrator; member of the Editorial Board of Palaearctic Grasslands, Deputy Conference Coordinator

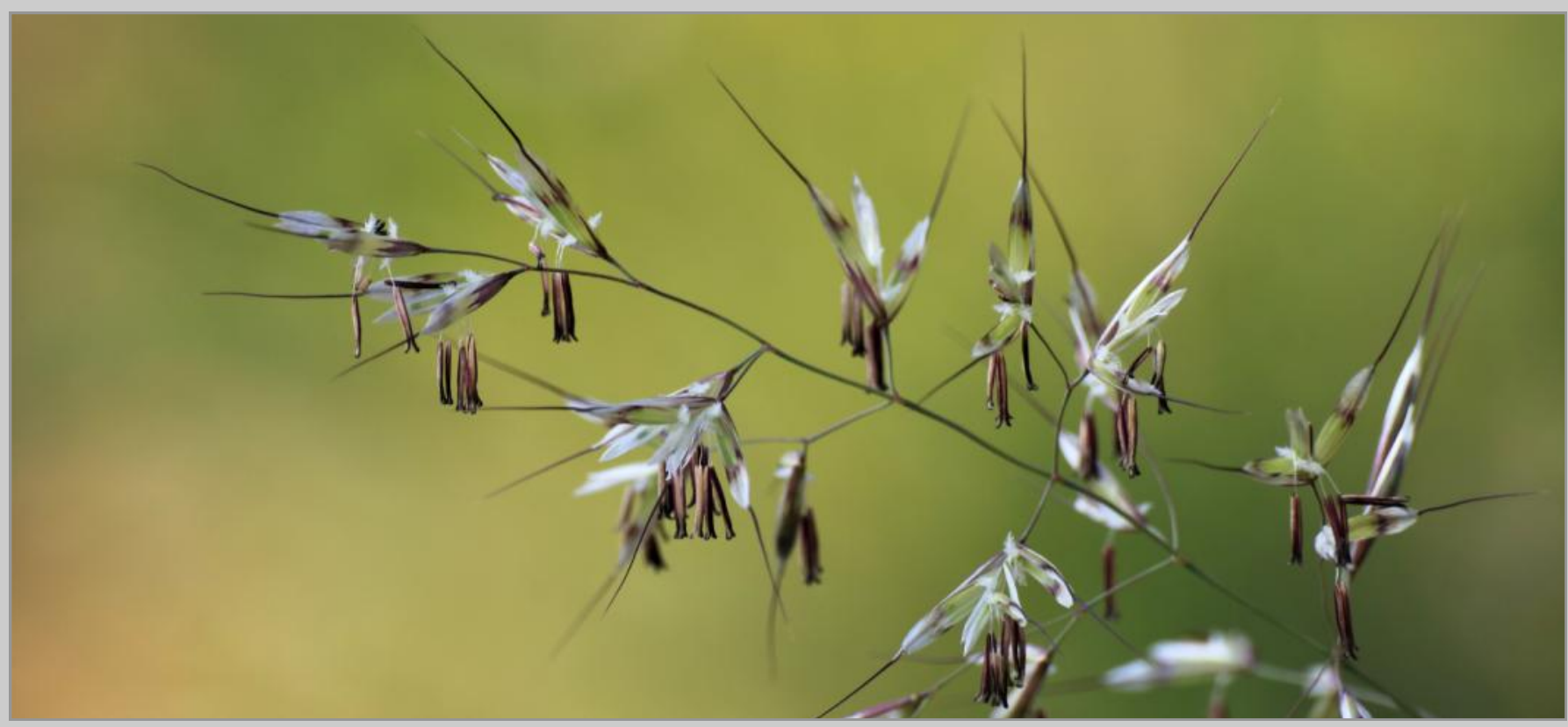

